\title{
NATIONALISM, MIGRATION AND EXILE: THE PHOTOGRAPHS OF YOUSSEF NABIL
}

by

\begin{abstract}
ANDREW GAYED in partial fulfillment of the requirements for the degree of:

\section{Master of Arts}

in

Art History, Theory and Criticism.

Degree Awarded June, 2015.

Carleton University, Canada

School for Studies in Art and Culture

Copyright 2015

Andrew Gayed

All Rights Reserved
\end{abstract}

A Thesis submitted to the Faculty of Graduate and Postdoctoral Affairs 


\begin{abstract}
In this thesis, I investigate Middle Eastern Contemporary Art and the photographic art that is being produced by artists from the North American Diaspora. Currently based in New York, Egyptian artist Youssef Nabil is the site of exploration that drive my theoretical ideas of exile and identity. Most importantly, I discuss how an Exilic Aesthetic is created through Youssef Nabil's self-identification in his mediated photographs, articulating cultural dichotomies facing the Middle Eastern diaspora in North America through his own visual narrative.
\end{abstract}

After having discussed diasporic and exilic identity, I explore the concept of Islamic/nonWestern Modernities and their relationship to displacement, trauma, and Arab sexualities/masculinities within a post-colonial framework. Through the analysis of Nabil's photographic art, my intent is to see if we can reach a Modernity narrative that works beyond sexual oppression versus acceptance, and instead examines a negotiation of diasporic sexualities by incorporating different sociological strategies to help selfidentification categories be less dichotomous. 


\section{AKNOWLEDGEMENTS}

I would like to thank the Social Sciences and Humanities Research Council for supporting my research, and awarding me the Joseph-Armand Bombardier Canada Graduate Scholarship. I would like to thank the generous funding from various bodies at Carleton University, including the Migration and Diaspora Studies Group, Centre for Cultural Transnational Analysis, and the Faculty of Graduate and Postdoctoral Affairs. It is by their generous support that I was funded to present this research at conferences before Canadian audiences, as well as internationally at Duke University and at Oxford University on two occasions.

I would like to thank the adjudication committee of Red Quill Books Publishing House for awarding me the graduate scholarship for research advancing the field of social justice, and the adjudication committee at Carleton University for awarding me the Imam Tawfiq Shaheen Memorial Scholarship for research advancing the field of Islamic arts, culture, history and tradition. Notably, the School for Studies in Arts and Culture at Carleton University, as well as the incredible faculty within the Art History department truly encouraged me to develop and grow this research to its highest potential, and I am grateful to them for supporting me and believing in my work.

I would also like to acknowledge my loving partner, Mathieu Bélanger, for providing support and encouragement throughout the entire journey of this graduate degree. Your patience, love, and humor enabled me to complete this dissertation, and you pushed me to always do my best.

Foremost, I would like to thank my thesis supervisor, Dr. Ming Tiampo. Through 
her mentorship, she devoted her time to fostering my research, and helped me grow as a scholar and researcher. It is by her mentorship that she devoted her time so generously to my project, and worked enthusiastically with me to support, encourage, and grow this research, helping me get the most out of my graduate degree. I would like to thank her for believing in me, and being an incredible mentor along this journey. I would also like to express my appreciation to my readers Dr. Ruth Phillips, Dr. Carol Payne, and Dr. Jodie Medd for their support during the defense of my thesis.

It is by the generosity of these individuals that my research was made possible, and I am truly grateful to have been supported so encouragingly throughout the tenure of my graduate research at Carleton University. 
Table of Contents

List of Illustrations ......................................................................................... vi

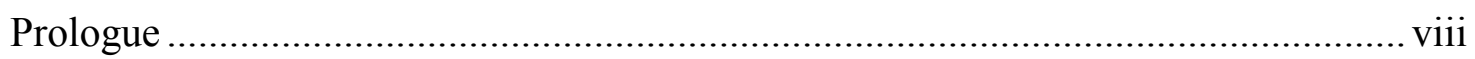

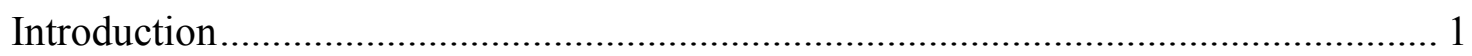

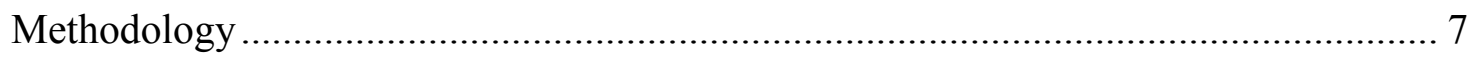

Literature Review..................................................................................... 10

Chapter One

The Exilic Aesthetic: Articulations of Patriotism by the Expatriate........................... 18

Chapter Two

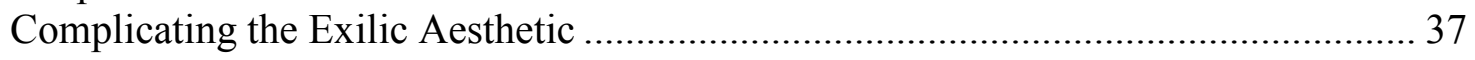

Chapter Three

Queering Middle Eastern Contemporary Art and its Diaspora................................ 49

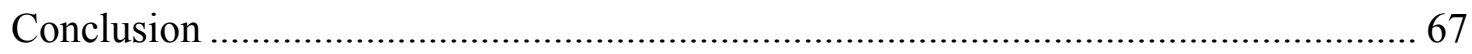

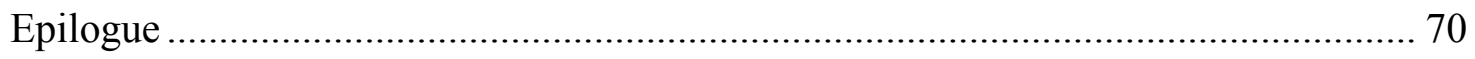

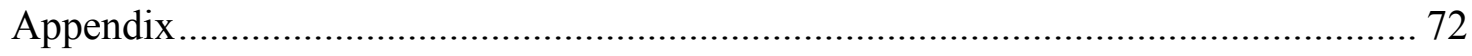

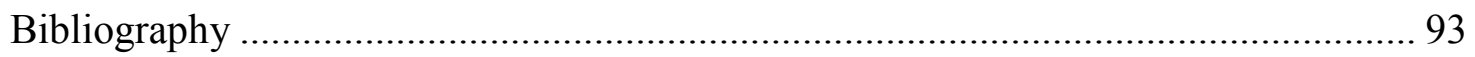




\section{LIST OF ILLUSTRATIONS}

(Figure A) STAR, New York, 2007. Youssef Nabil. Hand coloured silver gelatin print

(Figure B) Never Wanted to Leave-Self-Portrait, Paris 2007. Youssef Nabil. Hand coloured silver gelatin print.

(Figure C) Will I Ever Come Again-Self-Portrait, Havana, 2005. Youssef Nabil. Hand coloured silver gelatin print

(Figure D) I Leave Again-Self-Portrait, Sardinia, 2005. Youssef Nabil. Hand coloured silver gelatin print.

(Figure E) My Time To Go-Self-portrait, Venice, 2007. Youssef Nabil. Hand coloured silver gelatin print.

(Figure F) Self-Portrait with Roots, Los Angeles, 2008. Youssef Nabil. Hand coloured silver gelatin print

(Figure G) Freedom. Andrew Gayed. Black and White Inkjet Print. 2011.

(Figure H) Film stills from Sacrifice, video performance. Andrew Gayed. 2013.

(Figure I) Film stills from Baptism, video performance. Andrew Gayed. 2013.

(Figure J) Say Goodbye, Self Portrait, Alexandria 2009. Youssef Nabil. Hand coloured silver gelatin print.

(Figure K) You Never Left \#1, 2010. Youssef Nabil. Hand coloured silver gelatin print.

(Figure L) Four Pyramids, Giza, 1992. Youssef Nabil. Hand coloured silver gelatin print.

(Figure M) Sphinx, Giza, 2008. Youssef Nabil. Hand coloured silver gelatin print.

(Figure N) Palm Trees, Cairo, 2008. Youssef Nabil. Hand coloured silver gelatin print.

(Figure O) Malik Sleeping, Paris, 2005. Youssef Nabil. Hand coloured silver gelatin print. 
(Figure P) Ahmed in Djellabah, New York, 2004. Youssef Nabil. Hand coloured silver gelatin print.

(Figure Q) Ali in Abaya, Paris 2007. Youssef Nabil. Hand coloured gelatin silver print.

(Figure R) What Have We Done Wrong, Cairo, 1993. Youssef Nabil. Hand coloured gelatin silver print.

(Figure S) Not Afraid to Love, Paris, 2005. Youssef Nabil. Hand coloured gelatin silver print.

(Figure T) Rashid With a Shisha in his Mouth, Paris, 2004. Youssef Nabil. Hand coloured gelatin silver print.

(Figure U) Bryan Ridley and Lyle Heeter. 1979. Robert Mapplethorp. 


\title{
PROLOGUE
}

\author{
My Story
}

For the purpose of this thesis, I feel it important to be forthcoming with my own subject position, and my connection to the research. Raised as a Coptic Orthodox Christian, I unfortunately always knew that my sexuality would never be reconciled with my cultural background and with my religious upbringing. Born in Toronto, my parents immigrated to Canada from Egypt, and I identify as a first-generation Egyptian-Canadian. While I tried hiding my sexuality from my family and the community for a number of years, it became clear that the articulation of both my Arabness and my sexuality was non-normative and non-conforming. Almost two years ago before writing this thesis I was outed by social media (Twitter), the one place I felt that I had the liberty to be open and follow queer organizations and human rights campaigns from around the world. This is where my father found out my association with queerness, and confirmed what had been unspoken and ignored for many years. I was kicked out and disowned by my family unit and abandoned by my cultural community, losing the friends I once had. The common theme that reoccurred was that I was disgracing the family, and that my parents had immigrated to Canada for a better life for their children, one they did not see in queer identity.

Waking up to priests in my home waiting to pray for me and explain the damnation of the gays, being chased around the house with holy water on more than one occasion, and family 
interventions outlining each passage of the bible that condemns homosexuality became all common events I encountered when visiting my family.

I completed a Bachelor of Fine Arts in Visual Arts with a minor in Women's and Gender Studies, and I feel like this is important to my story. As an artist I always produced work that was autobiographical and about the homosexual experience in the Middle East. I did not know it at the time, but this flourished into my Masters degree in Art History where I also look at how political art is being used by the Middle Eastern diaspora in North America by artists (like myself) to cope with issues of sexuality and trauma. My future Ph.D. in Art History and Visual Culture then becomes another part of my healing process; like all of the schooling I have done thus far, it helps me not only research and understand my situation better, but also contribute to the scholarship and fill in the gaps where my experience is not accounted for. This becomes an incredibly powerful tool for me to know that I am not alone in my experience, and to actively educate and voice my story in ways that are beneficial to myself and others. 


\section{INTRODUCTION}

Perhaps instead of thinking of identity as an already accomplished fact... we should think, instead, of identity as a 'production' which is never complete, always in process, and always constituted within, not outside, representation ${ }^{1}$ - Stuart Hall.

This thesis investigates Middle Eastern Contemporary Art and the political work that is being produced by artists from the North American diaspora. Examining the artworks of New York-based, Egyptian artist Youssef Nabil, I will foster new meanings of exilic identity and themes of migration, nuance issues of homeland and memory in relation to the diasporic community, and begin theorizing how the Middle Eastern diaspora in North America negotiate their sexualities in relation to their cultural heritage. I use the term exile to include a range of positions including geopolitical exilic identity as well as internalized exile. $^{2}$ Using Nabil's lens-based artworks as my site of exploration, the examination of exilic identity, the geography of the diaspora, and the ways in which sexualities are experienced by the diaspora will help nuance our understanding of diasporic articulation of culture, and what Nadine Naber refers to as "articulating Arabness."3

Stuart Hall is joined by many scholars who believe in the production of identity as an always-changing process, and never ending performance. Theorists such as Jacques Derrida, Judith Butler, Gilles Deleuze, José Esteban Muñoz and others have developed

\footnotetext{
${ }^{1}$ Stuart Hall, "Cultural Identity and Diaspora," in Identity: Community, Culture, Difference, ed. Jonathan Rutherford (London, UK.: Lawrence \& Wishart, 1998), 222.

${ }^{2}$ Internalized exile is a term that I use which loosens the grips of the geographic association with exile. This opens possibilities for exile to be experienced by those not physically disassociated from their land in traditional understandings of exile.

${ }^{3}$ Nadine Naber, Arab America: Gender, Cultural Politics, and Activism (New York: New York University Press, 2012).
} 
ways of articulating the changing production of one's identity and self-identification. From Butler's performativity to Muñoz's disidentification, all of these theorists seek to deconstruct how dominant ideology negotiates minority culture and shapes the identities of who Gayatri Spivak calls the "subaltern."4

Art history as a discipline is currently undergoing a radical transformation that accounts for the transnational connections of the global art world and challenges the Eurocentric historiographies currently in place. Scholars such as Terry Smith, Paul Wood, Elaine O’Brien, Anna Brzyski, James Elkins and Ming Tiampo are but a few scholars aiming to complicate the narratives of a global art history, and determine a historical narrative that does not "other" non-Western art as periphery and derivative of the European canon. As Tiampo argues:

Articulating a World Art History is one of the most urgent issues facing art historians today, in both the academy and the museum. However, most attempts face a double bind: ambitious global narratives lack specificity and historical rigor, while precise micro-histories neglect range and the conceptual importance of rethinking larger art historical narratives. ${ }^{5}$

Terry Smith's Contemporary Art: World Currents ambitiously tries to map out such global narratives. His text argues that transnational visual cultures are reshaping our capacity to grasp the larger impacts of globalization and allows an imagining of local narratives within larger world-pictures.

\footnotetext{
${ }^{4}$ Subaltern is the social group who are socially, politically and geographically outside of the hegemonic power structure. Largely informed by Michel Foucault, Gayatri Spivak has been instrumental in writing about the voice and resistance of the subaltern. For more, please see: Gayatri Chakravorty, In Other Worlds: Essays in Cultural Politics (New York: Routledge, 1988); Gayatri Spivak, A Critique of Postcolonial Reason: Toward a History of the Vanishing Present (Cambridge, Mass.: Harvard University Press, 1999).

${ }^{5}$ Ming Tiampo, "Decentering Paris," in Postwar-Art Between the Pacific and the Atlantic, 19451965, ed. Okwui Enwezor, Ulrich Wilmes, Atreyee Gupta. Forthcoming.
} 
For any such global narrative to take place, art historians and critics are first faced with unpacking and identifying the baggage associated with the Western Canon, and the pitfalls associated with the entire system of cultural appraisal. The canon, defined as a body of works traditionally considered to be the most significant and therefore the most worthy of study, has been lately theorized as a mechanism of oppression, a guardian of privilege and a vehicle for exclusion. ${ }^{6}$ As Anna Brzyski states in the introduction to Partisan Canons, art history has been structurally committed to the idea of tradition, and that it is the only academic discipline within the humanities that has historically been dedicated exclusively to the history of a particular cultural form. ${ }^{7}$ This collection of essays asks where canons are formed, by whom, and how they are maintained, illuminating that until now, such questions have largely been ignored and accepted as unproblematic.

While the mission of my thesis is not to de-canonize nor even theorize this global art history, it is important to locate myself within the field of not just cultural studies, but the art historical discipline that contains the vocabulary of visual culture in its limited grasp. I argue for the importance of diasporic art as the diaspora gets left out of national histories or diasporic identity is assimilated to become the singular identity of the homeland, ${ }^{8}$ this has been how art history has conventionally been written. These studies have made it possible for analyses of global contemporary art to have greater resonance, as

\footnotetext{
${ }^{6}$ Anna Brzyski, Partisan Canons (Duke University Press, 2007), 1.

${ }^{7}$ Ibid, 5

${ }^{8}$ In The Location of Modern Art, Elaine O'Brian outlines how art history is written from national, continental, and regional points of view, but that the diaspora gets written from a global narrative that ignores the local. Here, she gives examples of how Black artists in Harlem created a Harlem Rennaisance in New York, but these artists are singularly identified as African American Artists, effectively erasing their diasporic identity and the local geographies relevant in their artistic production. This is found in the introduction of: Elaine O'Brien, Modern Art in Africa, Asia, and Latin America: An Introduction to Global Modernisms (Chichester, West Sussex; Malden, MA: Wiley-Blackwell, 2013).
} 
contemporary art is not typically the focus of these canon critiques. This project aims to add crucial discourse to transcultural visual art production, allowing Middle Eastern contemporary art to foster a more nuanced global art history highlighting geographical relevance in the art production of the diaspora.

In the first chapter, The Exilic Aesthetic: Articulations of Patriotism by the Expatriate, I discuss how what I call an Exilic Aesthetic is created through Youssef Nabil's selfidentification in his mediated photographs, articulating cultural dichotomies facing the Middle Eastern diaspora in North America through his own visual narrative. What I term an Exilic Aesthetic is not only about uncovering the lived experience of exilic artists, but (and more importantly), identifying a range of strategies that articulate the complex signifiers of an artwork, and understand their significance to larger thematic discourses around migration, articulation of culture, and expatriation. Relating this exilic experience to a visual language, I argue that given the importance of lived experience and first-hand accounts within sociological studies of expatriation, self-portraits such as these lend themselves to understanding the exilic experience, and illuminate how culture and nationalism are articulated by the Middle Eastern diaspora in North America. In this chapter I analyze theories of the nation in relation to the aesthetic function of Youssef Nabil's photographs to displace linear conceptions of nationhood and homeland. Narratives of the dispossessed, here, use art as a metaphor and signifier of national construction and cultural identity. When broadening notions of exile and expatriation, we can discuss their relation to one another to foster a new meaning of exilic identity, one that does not limit exile as only the involuntary departure from one's country, and one that 
creates an identity category that crosses borders and breaks barriers of thought and experience.

The second chapter, Complicating the Exilic Aesthetic, focuses on examining the ways in which the geography of diaspora shapes aesthetic choices. Examining my own artwork, issues of homeland are problematized and I theorize the use of photography as an identity-affirming narrative. Being Egyptian but born in Canada, my links to Egypt are vastly different than Cairo-native Youssef Nabil's. Although both working in North America, the differences in lens-based aesthetics will offer valuable insight to the impact of temporal geographies and the meaning/importance of homeland narratives to the diasporic artist. This conflict has to do with issues of culture and hybridity, their intersection, and how expatriates and exiles articulate culture. Using visual conventions almost opposite to those of the Exilic Aesthetic, my self-portraiture functions in radically different ways than those of Youssef Nabil. Examining these inconsistencies in relation to the different ways each of us experiences homeland is vital to developing a more nuanced understanding of the diasporic articulation of culture and experience. I will scrupulously engage with the literature surrounding national identity and nomadic identity in the first chapter, and examine artworks of different diasporic identities in order to nuance our understanding of these central ideas.

Lastly, the chapter Queering Middle Eastern Contemporary Art and its Diaspora investigates Middle Eastern homosexuality and focuses on issues of Modernism, multiple Modernities, and the West's claim to Modernity. While contemporary art is the focus of my analysis, Modernism and the turn of the Century mark a fundamental shift in Middle Eastern ideologies, as there is an increased association with Western Modernity. This 
discussion will have us thinking about Arab homo-sexualities in terms of desire and alternative masculinities rather than Western notions of homosexuality predicated upon homonormative models of visibility and coming out, narratives which are not conducive to understanding broader issues of homocolonial discourses, and how queer Arabs living in the West experience their sexuality. Here, the analysis of Youssef Nabil's photographs will help us investigate the codification of Middle Eastern masculinity through a visual language, and destabilize homo-colonial discourses of Western Modernity in a discussion rooted in sociological ideas of gender, nationalism, and sexuality, and the triangulation of identity and oppression that could arise at their intersection. My intent is to see if we can reach a narrative that works beyond the binary characterizations of sexual oppression (Middle East) versus sexual acceptance (North America), and instead examines a negotiation of diasporic sexuality by incorporating different sociological strategies to help categories of self-identification to be less dichotomous. What is imperative to this chapter is understanding how diasporic sexualities are actualized, and how Nadine Naber's ideas of "articulating Arabness" translates to diasporic versions of non-Western sexual identity in North America. 


\section{METHODOLOGY}

For this project, I have adopted a performative methodological approach to analyze visual art production, and more specifically, self-portraiture, as a useful and advantageous aspect of performative methodology to help better illustrate the impact of visual art within research production. This will allow for self-portraits such as Nabil's or my own to be used as a research tool to better understand diasporic categories of identity and selfidentification. Performative arts-based research is a relatively new methodological strategy accounting for a form of research that does not fit within the purview of qualitative and quantitative approaches. This performative methodology is also known as ResearchCreation. The most notable scholars in this field work with the Research-Creation thinktank at the University of Alberta. The group's manifesto concluded that self-portraiture could be a useful tool in sociological studies of identity:

We ask how the critical-discourse of research-creation might benefit from insights in the interdisciplinary humanities, the digital humanities, feminism and postcolonial discourses. We ask not only how research-creation is conceived and actualized by practitioners in these fields, but also how research-creation prompts critical new directions in the academy today. ${ }^{9}$

In his essay A Manifesto for Performative Research (2006) Brad Haseman proposes a performative paradigm for the creative arts, distinguishing it from qualitative and quantitative models of research. While Barbara Bolt's A Performative Paradigm for the Creative Arts? (2008) seems to skeptically accept the potential of a performative paradigm,

\footnotetext{
${ }^{9}$ Research-Creation Working Group. Knowings and Knots: Methodologies and Ecologies in Research-Creation. University of Alberta. (accessed December 3, 2014)
} 
she ultimately concludes that "whilst in the scientific paradigm, assessment of the validity of research lies in replication of the same, in a performative paradigm this requirement does not have validity. A performative paradigm would operate according to repetition with difference." ${ }^{10}$ Despite Bolt's interpretation of performative research as lacking scientific integrity, scholars such as Agnieszka Rydzik, Annette Pritchard, Nigel Morgan, and Diane Sedgley have successfully used arts-based performative research to explain how migrant women engaged with a research project and created artworks to represent their own trajectories, identities and experiences. ${ }^{11}$ They use a performative methodology within their study to gain insight into the experiences of a group of female migrants employed in tourism by involving them in an arts project which voiced their stories. Most telling of the success of their methodological framework, they concluded "such visual methodology could become an important tool for knowledge generation in collaboration with participants, particularly those most under-empowered in society." ${ }^{12}$ Here, it becomes clear how metaphor and artistic representations can offer insight that strict scientific models cannot.

Taking a less binary approach than Bolt's analysis, Tom Barone and Elliot W. Eisner have usefully outlined in their book, Arts Based Research (2012) that the arts should not try to replace science as the only mode of inquiry that produces human understanding. Instead, they argue that there are different ways of understanding the human condition, and

\footnotetext{
${ }^{10}$ Estelle Barrett and Barbara Bolt, "Practice as Research Approaches to Creative Arts Enquiry," (London: I.B. Tauris, 2010), 10.

${ }^{11}$ Agnieszka Rydzik et al, "The Potential of Arts-Based Transformative Research," in Annals of Tourism Research 40 (2013): 283-305.

${ }^{12}$ Ibid, 301.
} 
that the arts are among them. ${ }^{13}$ With this, it is my position that while there is mild contestation to the scientific authority of performative methodology, it introduces a level of subjectivity that is essential to better understanding the human condition. This scarcity of scientific repeatability then is not a weakness of this methodology as Barbara Bolt has argued rather, self-portraits and performative research help to illustrate themes that sociological and scientific texts cannot fully do on their own. Therefore, as Barone and Eisner have argued, I contend that self-portraits such as Nabil's are integral to better understanding sociological models of migration that are still being theorized today. Given the importance of lived experience and first-hand accounts within sociological studies of expatriation, self-portraits such as these lend themselves to understanding the exilic experience, and a performative methodology illuminates how culture and nationalism are articulated by the Middle Eastern diaspora in North America.

\footnotetext{
${ }^{13}$ Tom Barone and Elliot W Eisner, Arts Based Research (Thousand Oaks: SAGE Publications, 2011), 157.
} 


\section{LITERATURE REVIEW}

Diaspora studies has been a growing field over the past two decades. The Diaspora Journal's inaugural issue in 1991 arguably marked the start of institutionalized Diaspora studies, as it is where William Safran wrote his seminal text in an attempt to define diaspora consciousness. In this text, Safran concluded that the main features of the diaspora include: "a history of dispersal, myths/memories of the homeland, alienation in the host (bad host?) country, desire for eventual return, ongoing support of the homeland, and a collective identity importantly defined by this relationship." ${ }^{14}$ Unpacking the rigid guidelines Safran created in an attempt to define the diaspora, James Clifford encourages a multi-local definition of diasporic identity, stressing that transnational connections linking diasporas need not be articulated primarily through a real or symbolic homeland. ${ }^{15}$

Understanding diasporic identity requires the examination of both exile and nationalism, for migration is deeply rooted in the two. In a similar attempt at defining the parameters of expatriated identity, Edward Said's Reflections of Exile outlines the requirements for an identity based in exile to exist. These parameters will be explored in most depth within this analysis for they exemplify the foundational question that plague diaspora and nationalism studies - one of naming and defining the borders of identities. Examining cultural dichotomies that exist within the diasporic and exiled, Arjun Appadurai's theorization of

\footnotetext{
${ }^{14}$ William Safran, "Diasporas in Modern Societies: Myths of Homeland and Return," in Diaspora: A Journal of Transnational Studies. 1, no. 1 (1991): 83-99.

${ }^{15}$ James Clifford "Diasporas," in CUAN Cultural Anthropology 9, no. 3 (1994): 302-338.
} 
the five 'scapes' that constitute the disjunctures between economy, culture and politics makes clear how nation-states, multinationals, diasporic communities as well as subnational groupings and movements constitute the multiple narratives within the construction of nationhood. ${ }^{16}$ With this more fluid understanding of transnational identity, Nadine Naber's writing on "articulating Arabness" is a key bridge to understanding contemporary diasporic theory and how it relates to the post-9/11 lived experience of the Middle Eastern diaspora. This differentiation is highly relevant as it uses the sociological structures of diaspora and exile previously mentioned, but accounts for Islamophobic narratives steeped in issues of homonationalism ${ }^{17}$ and human security. Here, Naber focuses on the lived experience of the Middle Eastern diaspora in North America, and examines how recollections of homeland create an intensification of host-culture within the diaspora, complicating our understanding of transnational articulations of cultural identity.

The past three decades have seen an emergence of Western scholars interested in the representations of sexuality in the Arab and Muslim worlds, coinciding with the emergence of Western gay scholarship on sexuality. ${ }^{18}$ Joseph Massad has introduced what he terms the "Gay International," a mission of homocolonialism and Western exceptionalism that seeks to export Western models of homosexuality into places where it did not previously exist, effectively erasing local forms of sexual identity scripts. While I will return to the

\footnotetext{
${ }^{16}$ Arjun Appadurai, Modernity at Large: Cultural Dimensions of Globalization (Minneapolis, Minn.: University of Minnesota Press, 1996).

${ }^{17}$ Jasbir K. Puar, Terrorist Assemblages: Homonationalism in Queer Times (Durham: Duke University Press, 2007).

${ }^{18}$ Joseph Massad, "Re-Orienting Desire: The Gay International and the Arab World." Public Culture 14, no. 2 (2002): 365.
} 
merits and details of Massad's scholarship later within this analysis, it is important to understand this "Gay International" in relation to the rise of Arab Sexuality Studies in the context of imperialism, and its coinciding with the emergence of Western Gay Sexuality Studies.

While these more anthropological accounts of sexuality in the Arab world cannot be ignored as they "add greatly to current Western discourses about sexuality," ${ }^{19}$ Murray and Roscoe's collection from 1997 remains an important one. Moving beyond previous and colonial writings by journalists and tourists such as Schmitt and Sofer's Sexuality and Eroticism Among Males in Moslem Societies (1992), ${ }^{20}$ Murray and Roscoe's various contributions draw more specifically on contemporary ideas in sexuality studies, and give heavy emphasis to Islamic historiography. Building on the homocolonial theories of the Gay International, Massad is quite critical of Murray and Roscoe's collection, and holds the position that their writing is indicative of their limited knowledge of Muslim societies. ${ }^{21}$ Further than this, Massad also finds that Murray and Roscoe's book has language-based errors and mistakes when translating from Arabic, and holds that the issue becomes a fight to represent the so-called real Arab or Muslim position on male-male sexuality. ${ }^{22}$

\footnotetext{
${ }^{19}$ This quote was taken from the back cover of Stephen O. Murray and Will Roscoe, Islamic Homosexualities: Culture, History, and Literature (New York: New York University Press, 1997). This quote was a review given by the American Anthropoligist, and lays testament to the homocolonial discourse this wave of scholarship on Arab sexualities relies on, and its constant relation of Arab sexualities with Western notions of sexualities.

${ }^{20}$ Rahman Momin, Homosexualities, Muslim Cultures and Modernity (Basingstoke: Palgrave Macmillan, 2014), 73.

${ }^{21}$ Joseph "Re-Orienting Desire: The Gay International and the Arab World." Public Culture 14, no. 2 (2002): 370. Massad critiques the book, Islamic Sexualities to point out that Islamic is an adjective referring to the religion Islam, while Muslim refers to people who adhere to it; Massad points out that it is unclear how Islam, the religion, can have a homosexuality.

${ }^{22}$ Joseph Massad, "Re-Orienting Desire: The Gay International and the Arab World." Public Culture 14, no. 2 (2002): 371.
} 
The first wave of scholarship on the sexualities of the Arab or Muslim world has been relatively colonial and rather othering. Because of this, I will focus this literature review on a later generation of scholarship that is post-colonial in nature and that I find most reflective of the lived experience of Arab and Queer subjects currently a part of the North American diaspora. This schism in scholarship is also intentional to account for the difference in subject position and Arab-Muslim narratives in a post-911 context. This context separates all scholarship quite naturally as it shifts narratives of homoOrientalism ${ }^{23}$ to one of terrorism and identity categories viewed within the lens of homonationalism ${ }^{24}$ and human security. Therefore, this thesis will focus on these postcolonial writings in order to avoid the pitfall of homocolonial historiography, and to better account for the lived experience of the diaspora and the real life identities that the events of 9/11 have impacted.

I have explained in detail the conflicts surrounding scholarship of Arab sexualities because it helps us understand the issues addressed in the collection of essays in Islamicate Sexualities and its struggle with language and naming. Edited by Kathryn Babayan and Afsaneh Najmabadi, this more recent collection (2008) focuses on a wide cross-section of Muslim cultures ranging from Iberia in the mid-sixteenth century, to Arab literatures in Egypt from the late medieval times. Supported by a variety of historical literary studies, the anthology takes the task of naming language and translation as a primary dilemma within their arguments, avoiding falling into the pitfalls of Massad's Gay International and

\footnotetext{
${ }^{23}$ Homo-Orientalism follows the same pattern of reductive stereotypes and essentializing features of traditional Orientalist depictions, but highlight the sexually perverse nature of Arab men. This can be done by over-sexualizing the Arab men, making them promiscuous, and a level of homoeroticism adds to a visual narrative of sexual deviance.

${ }^{24}$ Jasbir Puar, Terrorist Assemblages: Homonationalism in Queer Times (Durham: Duke University Press, 2007).
} 
the risk of a homocolonial discourse. Conscious of this postcolonial trajectory, the editors chose Marshall G.S. Hodgson's coinage, Islamicate, which was intended to highlight a complex of attitudes and practices that pertain to cultures and societies that live by various versions of the religion of Islam. ${ }^{25}$ Used as a conceptual movement away from the nineteenth-century universalizing European idea, Islamicate refers not only to what is historically understood as Islamic but all that is associated with Muslim styles and modes of cultural expression.

Afsaneh Najmabadi's Women with Mustaches and Men without Beards provides a detailed account of normative gender scripts being re-written by narratives of Western Modernity, and the change in signifiers of femininity and masculinity in nineteenth-century Iran. Rather than strictly focusing on homocolonial discourses, Najmabadi's text adds crucial gender discourse to the notion of gender-colonialism and the assimilation of local gender-scripts after the nineteenth century in Iran. Rahman Momin's Homosexualities, Muslim Cultures and Modernity is also a valuable text in its assertions of intersectional identity as a mode of resistance. For Momin, intersectional identities (such as gay Arabs in the West) contribute to a disruption of Modernity narratives that underpin Western exceptionalism through queer politics.

Moving even farther away from the anthropologically centered Western scholarship of Arab sexualities is the recent two-volume anthology, Islam and Homosexuality, edited by Samar Habib. Intellectually organized by historical theorizations of Arab sexualities in volume one, and lived experiences of the diaspora in volume two,

\footnotetext{
${ }^{25}$ Kathryn Babayan and Afsaneh Najmabadi, Islamicate Sexualities: Translations Across Temporal Geographies of Desire (Cambridge, Mass: Center for Middle Eastern Studies of Harvard University: Distributed by Harvard University Press, 2008), ix.
} 
Habib's introduction directly addresses Massad's argument about the Gay International and homocolonial discourses of exporting Western homosexualities to the Middle East. Denying Massad's protest against the view that there is an authentic form of homosexual identity indigenous to the Arab World, Habib rejects Massad'a assertion that coming out and visibility strategies are Western imports that are colonial impositions, labeling this as oppressive to Arab individuals who do in fact identify as gay and still live in the Middle East. Shifting away from Massad's "incitement to discourse" theory, Habib formulates her arguments around a human rights discourse in an attempt to universalize human security and a need to rid social oppression that is a "universally shared physiology." ${ }^{26}$ This universally shared physiology is predicated in the assumption that everyone shares the same need of basic human rights and freedoms. In Habib's attempt to undermine Massad's denial of an indigenous homosexuality in the Arab world, I worry that she is re-packaging the incitement to discourse within a new, human rights framework. She asserts: "this was precisely how the Islamic states reacted to the Declaration [of Independence] which was seen as a culturally imperialist attempt to enforce one set of Rights..."27

Here, Habib is making, at its root, the same argument of colonial discourse that Massad makes. What Massad calls the homocolonial Gay International, Habib argues is the exportation of human rights in the name of colonialism. I posit that the question then becomes whether this exportation of human rights can happen in a way that allows for hybridity and the productive translation of these Western models. Where Habib truly

\footnotetext{
${ }^{26}$ Kathryn Babayan and Afsaneh Najmabadi, Islamicate Sexualities: Translations Across Temporal Geographies of Desire (Cambridge, Mass: Center for Middle Eastern Studies of Harvard University: Distributed by Harvard University Press, 2008), xxiii

${ }^{27}$ Ibid, xxii.
} 
differs from Massad is her argument of cultural specificity and respect of selfidentification. Specifically, she argues that:

The critiques of culturally insensitive approaches to sexual practices in the Arab world have overlooked their own insensitivity to the very real struggles of homosexual people in the Arab world (regardless of whether such a term is universally identified with, these individuals are in the least aware of their inherent difference and exclusion from the socially sanctified sexual currencies of marriage and children). ${ }^{28}$

With this thought, the lived experience of the homosexual-identifying subjects in the Middle East is more of a priority than the ways in which they came to label themselves. Habib sees risks in demarcating all homosexual identities in the Middle East as colonial legacies of Western sexual discourses, and rejects Massad's theoretical premise by rejecting the notion that "your sexual preference or identification is not really your own, it is a Western construct, [and that] you do not really exist." ${ }^{29}$

Other scholars have made similar human rights arguments such as Brian Whitaker's book, Unspeakable Love, Gay and Lesbian Life in the Middle East. While outlining key issues in Middle Eastern sexuality studies through interviews and first hand accounts, Whitaker takes a similar human rights stance that dichotomizes sexuality discourses into Western categories of identification, and that of the Other. This othering of sexual discourses that do not resemble that of Western homosexuality is one of the pitfalls this universalist human rights methodology creates.

\footnotetext{
${ }^{28}$ Samar Habib "Introduction: Islam and Homosexuality," In Islam and Homosexuality. Vol. 1. (Santa Barbara, Calif.: Praeger, 2010): xvii.

${ }^{29}$ Ibid, xviii.
} 
The question then becomes whether there is a way out of these dichotomies - between an "authentic" Arab Queer identity versus the homocolonial. My mission here is to introduce what narrative psychologist Sekneh Hammoud-Beckett has coined as "letting-in," a way to negotiate and alter Western narratives of coming out. This is a process that she describes as the conscious and selective invitation of people into one's "club of life" as she puts it. ${ }^{30}$ Here, letting-in is a process that is highly relevant to the diaspora, as it is a way to alter perceptions of what it means to live a truly gay life, and falsifies the Western need to become more visible in order to be complete. Nabil's artworks exemplify networks of communications that are different from the global-to-local homocolonial imposition of gay identity that most contemporary literature on the topic focuses on. Instead, I argue that these local networks are let-in by homosexual, queer, male-desiring subjects in North America, and gay Middle Eastern diasporic subjects are then creating an alternative coming out narrative and identity script than the inscribed Western model. These photographs then become just one example of how these local identity networks are transmitted through visual language.

\footnotetext{
${ }^{30}$ Sekneh Hammound-Beckett, "Azima Ila Hayati- an Invitation in to My Life: Narrative Conversations about Sexual Identity." in International Journal of Narrative Therapy and Community Work 2007, no. 1 (2007): 29-39.
} 


\section{CHAPTER ONE}

\section{The Exilic Aesthetic: Articulations of Patriotism by the Expatriate}

Edward Said's writing has taught us that human beings make their own history, and they also make their own cultures and ethnic identity. ${ }^{31}$ Survival in fact is about the connections between these things. Youssef Nabil's self-portraits will be the site of exploration that will drive my theoretical ideas of exile and identity. I will argue for exile as an identity category, and foster new meanings of exilic identity and themes of migration with Youssef Nabil's vibrant photographs as a case study for my analysis. Most importantly, I will discuss how Youssef Nabil's hand-painted photographs use a collection of visual strategies to create what I call an Exilic Aesthetic, articulating cultural dichotomies facing the Middle Eastern diaspora in North America through his own visual narrative.

Born in Cairo in 1972, Nabil grew up in Egypt as part of the Muslim majority. While studying French Literature and Arts at Ain Shams University in Cairo in 1992, Nabil was approached by American photographer David LaChapelle about filming in Egypt and finding Egyptian models. Nabil then worked with LaChapelle from 1993 to 1994 in New York, later going back to Cairo to finish his studies and military service. In 1997, Nabil met Peruvian fashion photographer Mario Testino in Cairo, and then went to Paris to work with him between 1997 and 1998. It was after this time that Nabil wanted to return to Cairo

\footnotetext{
${ }^{31}$ Edward W. Said, Culture and Imperialism (New York: Knopf publishing, distributed by Random House, 1993), 334.
} 
and start exhibiting his work. In an interview with Iranian artist Shirin Neshat, ${ }^{32}$ Nabil states that it was mainly in 2003 that he started producing self-portraits; it was the year he left Egypt to live in France. It is this pivotal moment in Youssef Nabil's art production that I want to focus on and assess the narrative function of his self-portraits, and how they foster new themes of migration and border crossing.

\section{HAND TINTING AND NOSTALGIA}

I would like to take the time to discuss the formal elements Nabil employs in his artistic practice. His photographs comprise of hand-tinted silver gelatin prints, disrupting our notion of the photographic medium. Hand painted photography is a traditional Egyptian photographic technique that was widely used from hand painted family portraits to hand painted movie posters in Cairo's streets. It is an old technique that was still practiced in Egypt in the 1970s and 1980s. Youssef Nabil went to one of the last portrait studios practicing this method of photography "to learn this old technique and be able to add a contemporary edge to it in [his] work." ${ }^{33}$ As Michael Stevenson discusses, Nabil's oeuvre engages with the discourse of both photography and painting. His work has been located within the Western art practices of David Hockney and Wolfgang Tillmans, ${ }^{34}$ but subtly shifting the way intimacy is represented, something rarely acknowledged in Western art practice and traditional portraiture. Formally, these photographs are not meant to be true-

\footnotetext{
${ }^{32}$ Ghada Amer, Faten Hamama, Youssef Nabil, Shirin Neshat, and Octavio Zaya. I Won't Let You Die (Ostfildern, Germany: Hatje Cantz Verlang, 2008), 10.

${ }^{33}$ Jeremy Sans. As Close As I Can Get. Interview with Youssef Nabil, Venice. June 2007. Access on artist website. http://www.youssefnabil.com/articles/as_close_as_i_can_get.html

${ }^{34}$ Tracy Emin, Youssef Nabil, Simon Njami, Mark Sealy, and Michael Stevenson. Sleep in My Arms (South Africa: Cape Town, 2007), 88.
} 
to-life representations as the medium would suggest, but hand-tinting the images transforms them into an uncanny and illusory form that is no longer within the bounds of traditional photography. Hand tinting is a method of manipulating these personal images as a subversive way to transform reality and interject lived experience and self-narration of one's personal reality. I argue that this hand tinting is useful to the destabilization of linear narrative, and achieves what Homi K. Bhabha describes in his writing as a necessary tool for incorporating subaltern narratives: a rupturing of "the past being linked to the necessary future. ${ }^{\prime 35}$ In this way, I will discuss how these artworks reflect identity navigated through exile and migration, and foster new ways of understanding expatriates and the broader migrant population.

\section{FROM arab to ARAB: THE CONSTRUCTION OF NATIONALISM}

To illustrate the construction of nationalism, national identity and ethnocultural identity, we must understand how personal identity can be crafted as a tool for both unification, and at times, postcolonial efforts. Pan-Arabism was proposed as a decolonized methodological notion that Gamal Abd al-Nasser, President of Egypt from 1954-1970, termed as the foundation of Al-Qawmiya al- 'arabiya - Arab Nationalism. Through colonization, Europe humiliated the ancient peoples of the Arabic-speaking Muslim lands ${ }^{36}$ but through efforts in unifying nationalisms, Nasser turned "arab" into "Arab." As Leila Ahmed writes in $A$

\footnotetext{
${ }^{35}$ Homi K. Bhabha, The Location of Culture (Special Indian Edition. New York: Routledge, 2004), 205.

${ }^{36}$ Andrew Hammond. Popular Culture in the Arab World: Arts, Politics, and the Media. (Cairo, Egypt: American University in Cairo Press, 2007), 13.
} 
Broader Passage, the key to a decolonized nationalistic identity could be found in Nasser's ingenious transformation of a term of derision into a term of cultural pride. ${ }^{37}$ Locating its roots in unity and collectivity in the face of oppression, Arab nationalism is the interrelated experience of a post-independence Arab nation, bringing mutual understanding between different Arab countries.

In STAR, New York, 2007 (Figure A), Youssef Nabil has taken screen-grab photographs of the iconic Egyptian singer, Oum Kalthoum, during a televised concert. Displayed as a vertical filmstrip, Nabil has hand tinted the images with the words "I die, I live forever, don't forget me, Amen" subtitled on the photographs. These photographs provide an exemplary starting point to conduct a visual analysis that can help illuminate issues of nationalism, cultural identity, and diaspora. With the four million fans attending Oum Kalthoum's funeral being a testament to her fame and splendor, she is remembered as a catalyst for Arab unity. Famed Egyptian actor Omar Sharif said of her “... (with) every rising sun, Um Kalthoum comes back to life in the hearts of millions of Arabs, and without her voice the days would fade in the Orient and colours would lose their brightness." 38 From the mid-thirties until a couple of years prior to her death in 1975, she held a concert on the first Thursday of every month. These performances were transmitted on the radio bringing the Arab world to a standstill. In honor of these famous broadcasts, her songs are still aired today at $10 \mathrm{pm}$ on the first Thursday of every month. Oum Kalthoum marks a time of major constitutional changes, including the revolution that forced the abdication of

${ }^{37}$ Leila Ahmed. A Border Passage: From Cairo to America- A Woman's Journey. (New York: Farrar, Straus and Giroux, 1999), 267-68.

${ }^{38}$ Miranda Sharp, Oum Kalthoum: The Fourth Pyramid exhibition review. (Contemporary Practices.Net); accessed online February 15, 2015. Page 60 http://www.contemporarypractices.net/essays/volume5/reviews/oum\%20kalsoum.pdf 
King Farouk, and President Gamal Abdel Nassar's mission of uniting the Arab peoples in one identity. Therefore, Youssef Nabil's artwork, STAR, New York, 2007 provides an incredible sociological text of the construction of nationalism, and one individual's illustration of cultural identity. The artwork's 2007 date is telling of the legacy Oum Kalthoum had in the national construction of Egypt, 32 years after her death. New York being listed within the title of the piece is telling of the complicated identity constructs facing the Middle Eastern diaspora in North America. New York being Nabil's current residence, it is extraordinary that this piece about Egyptian nationalism and cultural unity was produced outside of Egypt, complicating our understanding of homeland and issues of return.

\section{EXILE AS IDENTITY}

Exile in the legacy of the Western Empire reflects the consequences of modern warfare, imperialism, and the quasi-theological ambitions of oppressive regimes of power, perpetuating the high number of refugees, displaced persons, and need for mass immigration. Exile, as explained in Said's foundational text, Reflections on Exile, is described as being produced by human beings for human beings, a state of being that is meant to tear people from the nourishment of tradition, family and geography. ${ }^{39}$ Said makes powerful differentiations between exiles, refugees and expatriates, differentiations

\footnotetext{
${ }^{39}$ Edward W. Said, Reflections on Exile and Other Essays (Cambridge, Mass: Harvard University Press, 2000).
} 
that I will challenge in understanding exile as an identity category, and complicate its articulations in political art production.

While it is true that anyone prevented from returning home is an exile, exile originated in the age-old practice of banishment. Once banished, the exile lives an anomalous and miserable life, with the stigma of being an outsider. Refugees, on the other hand, are a creation of the twentieth-century state. According to Said, expatriates voluntarily live in an alien country, usually for personal or social reasons ${ }^{40}$ Here, the key word I wish to discuss is the use of the term voluntary; I wish to complicate the boundaries predicated by Said, dictating the distinctions between expatriate and exile. For these politicized categories of "voluntary" and "involuntary" do not account for migration and separation as a purposeful mode of survival, necessary for human safety. Youssef Nabil articulates his own experience with border-crossing and diasporic identity in his interview with Shirin Neshat, stating:

I think you leave your country only when you have to, when you feel that you can't live there anymore. You leave and try to find another place, where other people share your ideas, your thoughts, and your problems. In a way these people become like family and you create your own country around you, and this is what each of us did in a different way. ${ }^{41}$

This quote articulates that the act of leaving a place in and of itself is a politically charged action, for we leave out of necessity. This notion of necessity is one that I find too limited in Said's definitions demarcating the expatriates and those experiencing exile. For the boundaries become blurry when one is willingly leaving for personal safety, and there is a

\footnotetext{
${ }^{40}$ Said, Edward. Reflections on Exile and Other Essays. (Cambridge, Mass: Harvard University Press, 2000), 181.

${ }^{41}$ Ghada Amer, Faten Hamama, Youssef Nabil, Shirin Neshat, and Octavio Zaya. I Won't Let You Die. (Ostfildern, Germany: Hatje Cantz Verlang, 2008), 12.
} 
seemingly unintentional hierarchy of oppression created when discussing migration in these terms. In this way, I discuss exile in this paper as a blurring of the definitions predicated by Said, a mixture of both expatriatism and exile, comprising of an exilic identity that reflects the trauma of migration based on survival and personal necessity. When broadening Said's notions of exile and expatriation, we can discuss their relation to one another to foster a new meaning of exilic identity, one that does not exclude and limit the precursors of personal identification based on survival, and one that creates an identity category that crosses borders, and breaks barriers of thought and experience.

Nationalism needs to be contextually understood as an essential association with exile. Said defines nationalism as an assertion of belonging in and to a place, people, and heritage; it affirms the home created by a community of language, culture and customs. All nationalisms in their early stages develop as a condition of estrangement. In time, successful nationalisms consign truth exclusively to themselves and relegate falsehood and inferiority to outsiders. ${ }^{42}$ The perilous territory of not belonging and its site as identity formation is the aspect I am investigating. This is where people were banished in past histories, and where in the post-9/11 era, immense collections of peoples loiter as refugees and displaced persons. Nationalisms are about groups, but in the very acute sense, exile is solitude experienced outside the group. Exile cannot be discoursed independently from nationalism and nationhood, for the discussion needs to have almost a cause and effect relationship; one that acknowledges exile as being a byproduct of nationalism's instruments of othering those that fall outside its structures.

\footnotetext{
${ }^{42}$ Said, Edward. Reflections on Exile and Other Essays. (Cambridge, Mass: Harvard University Press, 2000), 176.
} 
I analyze theories of the nation in relation to the aesthetic function of Youssef Nabil's photographs to displace linear conceptions of nationhood and homeland. The crux of this argument relies on art as a metaphor of cultural construction that can account for the untold stories of the subaltern. Foucault describes the subaltern as being a set of subjugated knowledges or peoples that have been disqualified as inadequate. ${ }^{43}$ With Gayatri Spivak's text, Can the Subaltern Speak in mind, the Exilic Aesthetic enables metaphor to create a language for the subaltern to express themes of migration and exile through visual art production. Metaphor- as the etymology of the Greek word meaning "to transfer" would suggest - transfers the meaning of home and belonging by crossing borders of cultural differences that constructed nationalisms. However, it is this use of the metaphor that Homi K. Bhabha complicates in Dissemination, for he insists that the metaphor must be a non-linear narrative that highlights the intersections of time and place that problematize the modernity of the Western nation. ${ }^{44}$ For visual representation to function as the subversion of state and nationhood while simultaneously being a voice of subaltern identity, Frederic Jameson's notion of 'situational consciousness ${ }^{\text {"45 }}$ or national allegory is of use to my theory. In this, the telling of the individual story and the individual experience is ultimately involved in telling the collective narrative, and the multiple stories that constitute subjugated histories.

As the following section explaining the Exilic Aesthetic will illustrate, Youssef Nabil's lens-based artwork lends itself to this idea of one out of many. ${ }^{46}$ His artwork will

\footnotetext{
${ }^{43}$ Gayatri Spivak. In Other Worlds: Essays in Cultural Politics. (New York: Routledge, 1988), 25.

${ }^{44}$ Homi K. Bhabha, The Location of Culture (Special Indian Edition. New York: Routledge, 2004).

${ }^{45}$ Ibid.

${ }^{46} \mathrm{Ibid}, 204$
} 
stand as a telling detail that emerges as a metaphor for national existence, and a special expression of a collection of people.

\section{EXILIC AESTHETIC}

I don't think it's about where you actually live. For me it is about being honest, and about what you feel about yourself. No one can really tell us that you're less Iranian or that I'm less Egyptian because we live in the West, or that you're not supposed to be this or that ... We talk about issues that are related to us; we cannot do work that we have no relation to. ${ }^{47}$

Youssef Nabil's self-portraits employ a multitude of tactics that create a unique visual narrative, illustrating themes of migration. What I term an Exilic Aesthetic is not only about uncovering the lived experience of exilic artists, but (and more importantly), identifying a range of strategies and articulating their significance to larger thematic discourses around migration, articulation of culture, and expatriation. An Exilic Aesthetic is a collection of artistic strategies used for expressing exile through visual language; this chapter will analyze the artistic strategies found in Nabil's self-portraits thus far. These sociological themes of displaced persons are accompanied by a magnitude of cultural baggage, many of which are still being theorized by scholars today. Thomas Hylland Eriksen even writes that some of the most promising avenues of research into transnationalism concern the

\footnotetext{
${ }^{47}$ Ghada Amer, Faten Hamama, Youssef Nabil, Shirin Neshat, and Octavio Zaya. I Won't Let You Die. (Ostfildern, Germany: Hatje Cantz Verlang, 2008), 12.
} 
relationship between the old country and the new one. ${ }^{48}$ What I argue is that given the importance of lived experience and first-hand accounts within sociological studies of expatriation, self-portraits such as these illuminate how culture and nationalism are articulated by the Middle Eastern diaspora in North America, and how exile can be expressed visually. This complex web of nationalism and nationhood is a well-documented social struggle plaguing Middle Eastern diasporas in North America, a struggle Nadine Naber refers to as articulating Arabness. ${ }^{49}$ She identifies the banalities of identity formation as a struggle between two cultures, a dichotomy that is built between the immigrant population who clutch onto nationalism (and in effect intensify its tenets), resulting in a hyper-nationalistic identity that conflicts with their current geographical location. The binary is also enforced through American media outlets and anti-terrorist sentiments that are a result of the 9/11 attacks. While these points will be argued and discussed in greater detail later, we begin to see the importance and urgency of understanding the articulation of culture, nationalism, and identity formation of the Middle Eastern diaspora in North America.

Arjun Appadurai's theorization of the many 'scapes' that constitute the disjunctures between economy, culture and politics is helpful in understanding the production of this cultural dichotomization. Characterizing five dimensions of cultural flow- ethnoscapes, mediascapes, technoscapes, finanscapes, and ideoscapes $-{ }^{50}$ clarifies how nation-states,

\footnotetext{
${ }^{48}$ Thomas Hylland Eriksen, Ethnicity and Nationalism: Anthropological Perspectives, 3rd ed. (New York: Pluto Press; Distributed in the United States of America exclusively by Palgrave Macmillan, 2010).

${ }^{49}$ Nadine Naber. Arab America: Gender, Cultural Politics, and Activism. (New York: New York University Press, 2012).

${ }^{50}$ Arjun Appadurai, Modernity at Large: Cultural Dimensions of Globalization (Minneapolis, Minn: University of Minnesota Press, 1996).
} 
multinationals, diasporic communities as well as sub-national groupings and movements constitute the multiple narratives within the construction of nationhood. The artworks of Youssef Nabil provide an exceptional case study to understand how culture and identity are navigated through political art production, and how art is used as a means of necessity and a tool of self-actualization. It is this articulation of self that creates an Exilic Aesthetic, a visual language that illuminates Youssef Nabil's self-portraiture as a vehicle for understanding larger themes of expatriation and articulating Arabness.

This photographic language fosters new meanings of exile and expatriation, as well as creating a unique aesthetic. When these narrative structures are employed together, they demonstrate thematic tensions of displacement and the complexity of homeland narratives. While the strategies employed by the artist are repeated in a sometimes archetypal fashion, I will discuss a few specific pieces that best represent the conflicting narratives within Nabil's self-portraits. It should also be noted that Nabil's self-portraits tell a very different story than his portraits of celebrities and friends, and the latter will be discussed in separate chapters of this analysis. It is through the use of language, composition, fragmentation, and juxtapositions that these narrative tools are combined to create an Exilic Aesthetic.

First, I would like to emphasize the use of language, and how the titles of each selfportrait reflect themes of displacement and nomadic existence. The use of language is best exemplified when looking at Never Wanted to Leave-Self-Portrait, Paris 2007 (Figure B); Will I Ever Come Again-Self-Portrait, Havana, 2005 (Figure C); and I Leave AgainSelf-Portrait, Sardinia, 2005 (Figure D). The self-portraits are purposefully taken outside 
of Egypt ${ }^{51}$ linking his identity to a current location. This idea of being dislocated and uprooted is a reoccurring theme in Nabil's work, also noted in the numerous self-portraits, most with different geographical locations, and all consistently labeled "self-portraits" regardless of location. The poetic titles also play a large role in understanding migratory notions of identity and nomadic existence. When looking at Never Wanted To Leave (Figure B), the audience is unsure if Nabil is referring to leaving Cairo, his native place, or Paris, the place he left in 2006 to move to New York. Given the context of Nabil's border crossing, homeland is a blurred concept, and is further implicated by notions of culture and heritage. In her writing, Keri E. Iyall Smith discusses Georg Simmel's 1908 essay The Stranger, characterizing the stranger as occupying a hybrid identity space. The stranger arrives today and has the potential to leave tomorrow; strangers are simultaneously members of the community and not members of the community at all. ${ }^{52}$ As the stranger is an identity that might emerge from combining two separate identities (as we see in the hybrid identities of the diaspora), a solution I pose through an Exilic Aesthetic and reformulations of exile is to create a new identity that encompasses these local and global identity forms. In unpacking the many complex ideas of this argument, we need to ask ourselves, is hybridity simply the combination of two separate identities? What other options of identity formation are there for subjects in-between? Are those in-between necessarily the stranger? To help clarify the notion of stranger, I will use Ruth Phillips'

\footnotetext{
${ }^{51}$ The photographs Youssef Nabil takes when he returns to Egypt follows a very different narrative structure, and will be discussed in Chapter Two under the subheading, Return to Homeland.

${ }^{52}$ Kurt H. Wolff. The Sociology of George Simmel. (London: Free Press of Glencoe, 1950). Also referenced in Keri E. Iyall Smith and Patricia Leavy, Hybrid Identities: Theoretical and Empirical Examinations. Studies in Critical Social Sciences. (Boston: Brill, 2008), 4.
} 
notion of the stranger-artist, a political refugee, an immigrant, a traveler. ${ }^{53}$ While Phillips develops her definition to complicate settler-colonizer relationships with indigenous artists, the idea of the stranger-artist in its broader sense as describing the artist as de-territorialized through exile and immigration can be useful in contextualizing stranger identity.

Here, with the artist as stranger, we can see how political art production can be used as the tool to navigate these murky waters, and help articulate this new identity and selfactualization when understanding culture, homeland, and exile, and the intersection of them. Both Will I Ever Come Again (Figure C) and I Leave Again (Figure D) follow a similar theme of disassociation with the land, yet simultaneously the land is also intertwined in Nabil's self-identification, as reflected in his incongruity of location, and where homeland really is.

Another narrative tool used by Nabil to represent nomadic existence is composition. Rarely presenting his face to the viewer, these self-portraits are taken with his back to the camera. This shielding of his face is a narrative tool that reoccurs in many of Nabil's portraits, working synergistically with the conflicting titles to create tension and fragmented notions of identity. In an interview with Jerome Sans, Nabil talks about his self-portraits being "a witness of this reflexion and the stories it has generated from place to place as each portrait is done in a different city, I felt in all of them that I was a visitor and I had to leave... the same feeling I had when I was living in Egypt... the same feeling I always had about my

\footnotetext{
${ }^{53}$ Ruth Phillips. "The Turn of the Primitive: Modernism, the Stranger and the Indigenous Artist," in Exiles, Diasporas \& Strangers. (London: Iniva, Institute of International Visual Arts, 2008), 47.
} 
whole existence." 54 Here, we see the narratives in each piece work together as a collection of disjunctive identity formations, giving as a better idea of the effect of displacement and expatriation has on self-identification, and how this complexity is navigated through political art production.

As seen in the three portraits discussed thus far, the fragmentation of Youssef Nabil's body in his photographs can be interpreted as a disjuncture of identity, never letting the viewer see Nabil in his entirety. This poetic representation of himself as fragmented is also joined with visual clues to add emptiness and alienation with a place as seen in My Time To GoSelf-portrait, Venice, 2007 (Figure E) or symbolic references to homeland and roots, as seen in Self-Portrait with Roots, Los Angeles, 2008 (Figure F).

When looking at My Time To Go-Self-portrait, Venice, 2007 (Figure E), the narrative convention discussed earlier shifts slightly, showing us a profile of his face. This diptych however functions differently than the other narrative structures, for an empty bed in one of the pictures is juxtaposed against Nabil lying restlessly in the other. This empty bed is shown creased and unmade, with a visible imprint of Nabil's presence from the sister photograph displayed next to it. Nomadic existence is further emphasized in these photographs, showing the imprint of the self and the impermanence that is thematically rendered in all of Nabil's self-portraits. This visual structure (and the ones previously

\footnotetext{
${ }^{54}$ Jeremy Sans. As Close As I Can Get. Interview with Youssef Nabil, Venice. June 2007. Access on artist website. http://www.youssefnabil.com/articles/as_close_as_i_can_get.html
} 
discussed) is a larger composite of visual cues that creates a language for collective human existence and migration. To make this point clearer, Said's text Movements and Migrations lends itself as a tool to understanding resistance imagery and opposition to the empire. Said sees this resistance and self-identification as hybrid counter-energies which are based on discontinuity, political experience based on communities and interpretation rather than the powerful hegemony that dictates the identities of less powerful minorities. In this way, Nabil's diptych is adding to a larger narrative (in conjunction with his other self-portraits) that actively renews and re-invents his identity opposing the hegemonic powers that create exile and expatriate its citizens. The difficulty in navigating this space of identity building is best identified by Shirin Neshat and her articulation of being a part of a global village:

Very few Muslim artists that I know seem to have the luxury of showing their art both in their own country and in the West. In the case of some artists like you and me, our public is mostly outside of our country, and at home people can only access it through the Internet. We therefore have a divided audience, with some who don't entirely understand the work but are drawn to it (in the West), and others who understand it but mostly dismiss it (in the Middle East). So we as artists learn to live in what they call the global village, and try to survive both emotionally and professionally. ${ }^{55}$

Speaking directly to displaced persons and the articulations of culture and personal identity, Neshat's statement illuminates the complexity of diasporic artist and the struggles expatriates face in finding their own voice, and connecting it to their homeland.

In Self-Portrait with Roots, Los Angeles, 2008 (Figure F), themes of homeland and belonging are expressed in the literal representation of roots. Once again showing a side profile, Nabil's body is fragmented and the composition is unbalanced with his body in the top corner of the image. Showing himself as a small part of a larger picture, the roots are

\footnotetext{
${ }^{55}$ Ghada Amer, Faten Hamama, Youssef Nabil, Shirin Neshat, and Octavio Zaya. I Won't Let You Die. (Ostfildern, Germany: Hatje Cantz Verlang, 2008), 15.
} 
engulfing his presence in the pictorial frame. In this picture, nature and environment are used to emphasize notions of displacement homeland, using the literal soil of Los Angeles to signify homeland, or a loss thereof. The visual depiction of roots is ironic when looking at Nabil's repertoire of self-portraits, one that implies the inability to form roots and the lack of the stability that comes with roots. Complicating our understanding of his identity in a (once again) contradictory intent. As Nabil says, "I do my self-portraits in cities that I visit, in which I am just a visitor. I know I will be leaving in a few days. I feel the same way about my whole life, up until death. For me living is about coming to a place that is not yours, then having to go. ${ }^{~} 56$ Nabil's visual narrative in his self-portraiture seems to be self-antagonizing, creating a disconnect between language, imagery, and selfrepresentation. This disconnect is used as a tool to articulate themes of expatriation, and also create a barrier to be experienced by the viewer, a barrier that prohibits a true understanding of Youssef Nabil from his self-portraiture. Emphasizing the importance of land, and homeland being an essential point of articulation within an Exilic Aesthetic, Bhabha correspondingly wrote "the recurrent metaphor of landscape as the inscape of national identity emphasizes the...question of social visibility, the power of the eye to naturalize the rhetoric of national affiliation and its forms of collective expression." ${ }^{57}$ This conflicting narrative is one that contributes, as I have argued, to an Exilic Aesthetic, one that allows the viewer to read the sociological impacts of migration and the simultaneous separation/articulation of culture, nationhood and identity.

\footnotetext{
${ }^{56}$ Ghada Amer, Faten Hamama, Youssef Nabil, Shirin Neshat, and Octavio Zaya. I Won't Let You Die. (Ostfildern, Germany: Hatje Cantz Verlang, 2008), 11.

${ }^{57}$ Homi K. Bhabha, The Location of Culture (Special Indian Edition. New York: Routledge, 2004), 205.
} 


\section{PHOTOGRAPHY AS LANGUAGE}

Important to the success of an Exilic Aesthetic being read (subconsciously) by viewers is piecing together visual clues that comprise a complex visual narrative that is unique to articulating the expatriate's identity. For this to happen, identity needs to be formed through visual elements that compose a visual language, a language that is the vessel for articulating an Exilic Aesthetic. This visual narrative is a way to express the complex signifiers of an artwork (in this case the self-portraits of Youssef Nabil), and understand their significance outside the sole experience of the individual artist, but as a signifier to larger thematic discourses around migration, articulation of culture, and expatriation.

Interestingly, Said speaks negatively of photographs or texts that are used "merely" to establish identity and presence for their innately ambiguous and anti-narrativist subjectivity. ${ }^{58}$ Taken from John Berger's writing, Another Way of Telling, Said claims that photographs such as these, ones that solely depict a sense of presence, enter what Berger calls a control system. Using Berger's analysis, I would like to create another reading of these "wayward" photographs, and show how Youssef Nabil's self-portraits cannot be restricted to such reductive definitions, even if they are meant to be representative images of himself (being innately ambiguous to use Said's terminology). The premise of the photographic medium as Berger describes it, is one that does not even lend itself to Youssef Nabil's work, I argue, because of the way he hand paints his photographs, thus blurring the distinction between media. Berger explains "you can only make a photograph tell an

\footnotetext{
${ }^{58}$ Edward W. Said, Culture and Imperialism, (New York: Knopf publishing, 1993), 334.
} 
explicit lie by elaborate tampering, collage, and re-photographing. You have in fact ceased to practice photography. Photography in itself has no language which can be turned." $" 59$

With this, I would like to argue two points. Not only does Nabil then cease to fit within the traditional criticism of photography and its medium by Berger's definition, but also that the Exilic Aesthetic described in this essay can be the language created in these photographic narratives that is outside the conventional language of photography. I would like to show that Nabil manipulating the photograph is a political act, which not only establishes presence, as Said describes, but inserting his own narrative and subjectivity into the pictoral depiction of the photograph and its geography is an innately subversive action. In this way, Nabil is effectively writing his own history from the margins of photography. In being outside the narrative language Berger describes, one that is not innately photographic, this is where Nabil employs the Exilic Aesthetic to create a language expressing themes of migration, homeland, displacement, and diasporic identity within his solitary self-portraiture.

Next, Berger describes photography as being invented for two reasons. The first is an ideological use, which treats the positivist evidence of a photograph representing truth, and the second is a popular but private use, which cherishes a photograph to substantiate a subjective feeling. ${ }^{60}$ Here, I argue that Youssef Nabil does not fit merely in either category; for while the most obvious category in which his self-portraits belong is the latter, I argue that the self-narration of his photographs asserting his own identity narrative can also be

\footnotetext{
${ }^{59}$ John Berger and Jean Mohr. Another Way of Telling. (1st American ed. New York: Pantheon, 1982), 96.

${ }^{60}$ John Berger and Jean Mohr. Another Way of Telling. (1st American ed. New York: Pantheon, 1982), 111.
} 
seen in the positivist category of photography, one that exists to represent truth. Abstractly, this representation of truth is one that relates to an Exilic Aesthetic, a form of representation from the margins, and as we learned from Said, the "exile's life is taken up with compensating for disorienting loss by creating a new world to rule." ${ }^{61}$

Here, this new world to rule is one that merges both Said's theorization on exilic experience and Berger's model of photographic representation to help illuminate the language created by artists in marginal states of existence. An Exilic Aesthetic then is a range of aesthetic strategies used as a tool for articulating the exilic subject. While the aesthetic may not be created intentionally, it helps understand art production as a way of self-identification and assertion of the self while articulating themes of migration and diasporic identity. This new world is seen in the mediated photographs of Nabil, and self portraits such as Never Wanted to Leave-Self-Portrait, Paris 2007 (Figure B) or SelfPortrait with Roots, Los Angeles, 2008 (Figure F) become just examples of how language, composition, fragmentation and juxtaposition are used to create an Exilic Aesthetic, and foster a visual language to articulate the complexities of diasporic identity.

\footnotetext{
${ }^{61}$ Edward Said. Reflections on Exile and Other Essays. (Cambridge, Mass: Harvard University
} Press, 2000), 145. 


\section{CHAPTER TWO}

\section{Complicating the Exilic Aesthetic}

In examining Youssef Nabil's self-portraiture thus far, we can see how the visual language of an Exilic Aesthetic allows for a discursive dialogue about the political art production of the diasporic artist, which can be a useful tool in understanding sociological notions of migration and transnational identity. I now wish to complicate the way we read the Exilic Aesthetic, and push the boundaries in which its sociological foundation can be used in an art historical trajectory. To do this I will further thwart the complex relationship between exile and birthplace, and discuss the Exilic Aesthetic as it pertains to the transnational structure of other diasporic identities. Doing so will determine how homeland and birthplace result in different uses of the body in self-portraiture, differing uses of titles as cultural-signifiers, and different narrative conventions under the lens of an Exilic Aesthetic. I will do this by discussing my own artwork, and focus on the vital differences within my artwork that can be linked to my Canadian birthplace; in doing so, I propose a visual language that conceptualizes an Exilic Aesthetic in a way that articulates multiple diasporic identities within its framework.

Born in Toronto Canada, I am an Egyptian visual artist and art historian. Identifying as a first-generation Canadian-Egyptian male, notions of race, displacement, and tolerance are foundational in my practice. As members of the Coptic Orthodox Church, being the Christian minority in Egypt has affected my family's cultural and religious notions of identity. Coming from a conservative, hyper-religious immigrant family, art became my 
voice in making sense of the political, cultural and religious tenets that conflicted with my transnational identity and my personal ideologies. Excommunicated from the Coptic Orthodox Church community and disowned by my family unit, I find myself adopting exile as an identity category, re-conceptualizing what it means to be an exile within my diasporic community, and its conflation with my birthplace. Functioning between two sets of cultures and dogmas, I develop my art as a tool to help better understand my own beliefs and myself as a cis-gendered Egyptian-Canadian male fighting for human rights and acceptance. Understanding notions of hybridity and transnational identity from a first-generation diasporic experience becomes a vantage point to better understand the artworks of the Middle Eastern diaspora in North America, and notions of articulating Arabness.

To help complicate the Exilic Aesthetic, I will reflect upon the use of the body within my own artworks, and see how they differ from how Youssef Nabil uses his body in his mediated self-portraits. I have already established the use of fragmentation and lack of facial reveal within the Cairo-native's photographs, and this changes drastically when looking at how I use my body as a tool within my artworks - showing my face and asserting my presence within the work. To start, the photograph Freedom, 2011 (Figure G) is a full-frontal self-portrait where I am gagged by the Egyptian flag, with the word Hurraya (freedom) written in Arabic across my forehead. Engulfed in darkness and slightly off-center in the frame, my body is consumed and disappearing into its surroundings, only making visible my shoulders and head in this black and white photograph. This ambiguous setting void of any special context is a reoccurring stage in my self-portraiture, greatly differing from the importance of physical land and emphasis on location in each of Youssef Nabil's self-portraits. This difference is a key factor in seeing how homeland and birthplace 
are articulated between two sets of diasporic identities, and the different narratives that arise in their political art production. Directly looking at the viewer, I actively plead a sense of urgency, a sense of witness, and assert my presence in the narrative of Egyptian protest and communal upheaval. Being gagged by nationalist ideology, Freedom, 2011 is a social commentary and documentation of the 2011 Egyptian revolution, before the Egyptian people occupied Tahrir Square to overthrow dictator Hosni Mubarak, and a precursor to the Arab Spring. Contrary to Youssef Nabil's self-portraits, my face is in full view, and I return the gaze of the viewer to assert an active consciousness, and the visibility of my subject position. Here, the idea of the stranger-artist is again useful, and this idea of being deterritorialized when conceptualizing transnational baggage. Born in Toronto, my links to Egypt are vastly different than Youssef Nabil's, and my assertion and claim to the land use an alternative narrative structure than that of Nabil's. My deterritorialization stems from being born in Canada, mediating the ensnaring dichotomies of my Egyptian culture and Egyptian homeland. Being deterritorialized in a different way than Nabil, my assertion to homeland in my self-portraiture nuances the viewer's understanding of how my body is used to write the narrative of identity and to insert myself within Egypt's own political narrative, blurring the geographical notions of homeland and identity. Asserting my presence then becomes a mode of self-actualization within my cultural history and the socio-political narrative of Egypt. In this way, writing myself into the nationalist script of identity functions in a similar way to Nabil's mediated, hand-painted photographs that are used as a way to insert his own subject position into his self-identification. Both photographs are mediated in some way - one through the medium and painting of the photograph, the other through the body as a performative tool of cultural identity. They 
thus take different approaches to articulate their relation to homeland and cultural ties. Freedom, 2011 nuances language of the Exilic Aesthetic, increasing its vocabulary and visual literacy by encompassing multiple diasporic identity narratives within its framework. This inconsistency of the use of the artist's body is far from an oversight, for it becomes a valuable tool to better understand the importance of geographical location and the relevance of homeland and birthplace to the artwork of the diasporic artist, and the art of the first-generation diaspora.

The use of the body as well as the titles of my artwork can be analyzed through the next two video works. In the Holy Week performances (which comprise Sacrifice, 2013 [Figure H] and Baptism, 2013 [Figure I]) the titles speak of identity in an ideological sense, and carry with them the cultural signifiers that make up my conceived identity. These signifiers are emphatic of my own personal relationship with my culture, my struggle with religious dogma, and the dichotomization that affects my self-identification. Once again connecting homeland and birthplace, the use of identity signifiers in these titles then become more cultural than in Youssef Nabil's titles which are linked to physical land, yet still indicates my estrangement from land and migratory themes of relocation through culture. This shift in identity signifier is not something to be glossed over, but conceptually understood as a cornerstone that will help us understand Nadine Naber's theorization of articulating Arabness more coherently. The Exilic Aesthetic then looks at the language used in the artworks of both artists, and highlights how the estrangement to land can function as the physical relocation of the body (as seen in Youssef Nabil's self-portraits), as well as the shifting of cultural signifiers that link a person to their homeland (as in my own artwork). 
In the video documentation of the Sacrifice, 2013 performance, I anoint my face with animal blood, repeating the sign of the cross in a ritualistic ceremony. In Coptic and Arabic, I chant mourning and funeral songs of the Coptic Orthodox Church, traditionally sung on Good Friday. My shoulders and head fill the frame's composition, and I actively stare at the viewer while anointing my face with animal blood, never breaking eye contact. Repeatedly — almost obsessively — anointing my face, I become drenched in blood, and the scene takes a visceral turn near the end when I violently smear my face with the sign of the cross until blood is dripping off my nose. Necessary to my relationship to homeland and its physical location, the scene is void of any spatial context, and I stand before a neutral grey background to disassociate myself with any physical place. The animal blood references the sacrificial lamb that is a reoccurring theme in religious mourning rituals, and popular imagery in medieval and renaissance altar paintings. Here, I bring the sacrificial lamb into the contemporary dialogue of scapegoating and ritualistic isolation and excommunication. In this video, I take control of my excommunication and use the tenets of the Coptic Orthodox Church to subvert their meaning, making the video an act of resistance and reclamation. Chanting the mourning psalms myself adds another level of cognizance to my own excommunication from the church, and creates a link between the tradition I grew up with, and cultural ties I can no longer practice. As mentioned showing my face and directly returning the gaze of the viewer, I am actively asserting my body in both cultural and religious traditions that become signifiers of my identity. Filling the frame's composition, this visually aggressive assertion can be contrasted to the almost ambivalent use of the body in Youssef Nabil's self-portraits, and their level of ambiguity in addressing both the land and the viewer of the artworks. Sacrifice 2013, then becomes a 
way to articulate how the restrictive and ostracizing tenants of both culture and religion are navigated and understood, subverting their meanings and articulating them in alternative ways. Here, the land is a fictitious one, for the idea of homeland is blurred between Toronto and Egypt. Creating an ambiguity regarding exilic identity, ostracization, and Egyptian and Canadian cultures, the grey neutral background helps complicate my relationship to homeland. While the physical location of my birthplace is indeed Toronto, my cultural identification is that of Egypt; therefore the cultural signifier of identification needs to be discoursed in a transnational and diasporic understanding of border crossing.

Further complicating signifiers of homeland and deterritorialization, Baptism, 2013 blurs the distinction between my own birthplace of Toronto, and the way I experience my Egyptian culture in Canada. In Baptism 2013, I wash my face with holy water, and scrub my it with the hate mail I received from the Coptic community in Canada, and letters from my brother disowning me. In Coptic, a congregation sings joyous songs of resurrection and life, a hymn that is sung on Easter ceremonies. Using the same visual composition of the sister video, my shoulders and head assert dominance in the frame, and tower over the viewer with an uninterrupted gaze. Starting to scrub my face gingerly with the hate mail and holy water, the video's climax is when I violently scrub the hate mail while cleansing my face of blood, shredding the remnants of the letters in the process. As in Sacrifice, 2013, the scene is void of any context as I stand before a neutral grey background, disassociating myself with any physical place. In using a congregational hymn for Baptism, 2013, I implicate the viewer in the process of identity formation, and create a communal act in both my isolation and later reclamation. This ritualistic washing of my face ends with the violent scrubbing of the letters, shredding the last of the hate mail. In this ceremony, I use 
the signs of the church to subvert their meanings and reclaim their power in my own identity. While religion is not what I am reclaiming in the Holy week performances, subverting and taking the power out of the acts of excommunication and isolation become a part of my individual cultural identity as a Queer Middle Eastern male and a part of the diasporic community in Canada.

Once again the notions of land and homeland are blurred as I subvert the disownment of my family and the hate mail I have received, which act as a cultural signifier of my relationship to my culture and how I experience it in Canada. My videos complicate homeland narratives because in order for the hate mail to act as a signifier of my personal experience of Egyptian culture and my relationship to the Coptic Orthodox community, articulating Arabness therefore is not expressed through the land itself, the way we see in Nabil's self-portraiture. The physical land becomes an imprecise way of discussing homeland, and examining the works of two diasporic artists with radically different transnational experiences helps highlight this last point. In the video documentation of the Holy Week performances, symbolism and imbued cultural text stand in for migratory themes of transnationalism, whereas Youssef Nabil's self-portraiture takes a much more literal use of the land in order to discuss the artist's relationship to homeland. While this is not to say Nabil's photographs should be reduced to a seemingly literal interpretation, the abstraction of culture and how I articulate this abstraction in my own self-portraits is of significance in understanding the difference between our work. In terms of aesthetics, this abstraction becomes a major factor resulting in my body filling the compositional frame, asserting my presence with my unwavering gaze, and imbuing cultural symbolism in the titles of my artwork to compensate for the contextual void in my neutral backgrounds. As 
seen in these three works, aggression is then mirrored with an assertion of Egyptian history and narrative, and my diasporic identity is therefore written and articulated through these self-portraits.

\section{RETURN TO HOMELAND}

While I have not addressed the issue of "return" thus far, it is a notion that runs through all sociological discussions of homeland, migration, exile, and diaspora. It is not enough to tie Youssef Nabil's connection to Egypt as only being his birthplace, for he returned to Egypt after 1994 to finish his studies and military service, and again after 1998 when he wanted to return to Cairo and start exhibiting his work. Scholars such as William Safran have even included "return," or the desire for return, as being one of several criteria for being considered a diaspora. ${ }^{62}$ This desire for eventual return argued by Safran functions very differently in my case, being a first-generation Egyptian-Canadian, as I have only returned to Egypt twice. While Egypt complicates my notion of homeland as it is what I have the most affinity to but yet is not my birthplace, Youssef Nabil's pattern of return, as well as the sociological narratives present in his photographs taken in Egypt illustrate the complexity of these two different diasporic identities.

The portraits taken within Egypt follow a completely different narrative structure. All of Nabil's self-portraits are taken outside of Egypt, but when he returned in 2009, he produced Say Goodbye, Self-Portrait, Alexandria, 2009. In keeping with the visual cues argued in the previous chapter, Nabil also has his back to the viewer, and he is paddling

\footnotetext{
${ }^{62}$ Safran, Diasporas in Modern Societies: Myths of Homeland and Return., 83-99.
} 
into the distance in a single-person boat. The language of this solitary self-portrait should also be noted, for it is interesting that while the anticipated event of "return" happens, the piece is despairingly titled "say goodbye." Nabil's photographs then complicate William Safran's predication of return being a necessary symptom of diaspora, for there seems to be an absence of affinity with the homeland once it is returned to. However the photographs taken outside of Egypt share a different narrative, one of loss and longing to return. The issue of not-belonging seems to plague both sets of photographs, and the notion of return becomes a weak measure of diasporic identity.

This despair of homeland and belonging is also seen in his first film, You Never Left, 2010, taking place in an allegorical "other place" of desert and Mediterranean settings that are a metaphor of Egypt, and I argue, Nabil's notion of homeland. This film is notable for it star actors Fanny Ardant and Tahar Rahim, yet still functions as a self-portrait that poetically tells the intimate story of exile and belonging. The complete physical absence of Nabil's body in his self-portraits taken in Egypt are highly relevant to our discussion of migration, as the visual aesthetics argued in the Exilic Aesthetic once again gets pushed farther when the physical land is that of Nabil's homeland.

Typologically speaking, photos such as Four Pyramids, Giza, 1992, and Sphinx, Giza, 2008 address these same issues of belonging and homeland as Youssef Nabil's physical body is absent from these photographs. Photographing these notable Egyptian landmarks, the absence of his body follows a similar pattern to that of shielding his face from the viewer, as discussed in the Exilic Aesthetic. Issues of memory and fragmentation are notably referenced in the photographs taken within Egypt, as Palm Trees, Cairo, 2008 
is manipulated to be choppy, fragmented and almost visually unreadable, giving the impression of palm trees rather than a true-to-life visual account of the scene.

The Exilic Aesthetic lends itself to explain the use of the body and its function to signify culture. It uses language as a strategy to help understand the experience of the diasporic artist, and expresses how art is used as a political tool to express sociological themes of migration, transnationalism and body politics. In the analysis of both Youssef Nabil's selfportraits and my own, an Exilic Aesthetic contrasts its language and visual narratives depending on the geographical location of the diasporic artist. In Youssef Nabil's selfportraits, an Exilic Aesthetic highlights the use of language to emphasize migration, the ambivalence of his body in the scene to discuss his articulation of identity, and the physical use of land and roots to ground himself to homeland. The Exilic Aesthetic as a language within my self-portraits highlights my contrived and forceful link to homeland by inserting myself in the Egyptian narrative, the use of language in my titles to emphasize cultural signifiers, and the assertive use of my body in the picture's composition to affirm my identity. A major thematic and aesthetic difference between both sets of self-portraiture is the physical setting: the ambiguity and contextual void of my self-portraiture is dramatically contrasted with Youssef Nabil's emphasis on current physical location and his relationship to the land where his self-portrait was taken. This difference is key to understanding the intersections of homeland, culture, and birthplace, and how the geographical location of the diasporic artist plays a strong role in their articulations of culture and identity. My relationship to Egypt is certainly different than that of Cairo-native 
Youssef Nabil; however our articulations of Arabness (and their necessary differences) are the very reason why an Exilic Aesthetic is a useful tool in analyzing the visual artworks of the diasporic artist. Methodologically, an Exilic Aesthetic also allows for a sociological reading of art historical narratives to introduce an interdisciplinary understanding of transnational baggage, migration, and diasporic identity.

Articulating Arabness and the dichotomies that ensnare the Middle Eastern diaspora in North America becomes a key concept in not only linking these two diasporic bodies, but also unifying how an Exilic Aesthetic can stand as a visual language for these two articulations of identity. Complicating the Exilic Aesthetic through the self-portraits of two diasporic artists is a way to interrogate the naturalization of the dichotomies between the "Arab" and "North American" cultures. Focusing on the lived experience of the diasporic individual, I unfreeze the essentialist understandings of Arabness that have come to be seen as frozen in time. Rather than Arabness being articulated outside of history, and as a legacy or Orientalist stigma, re-conceptualizing the articulations of Arabness from different diasporic identities helps delineate the historic narrative of migration and cultural identity. The notion of authenticity in relation to identity needs to be discussed and demystified within this context. As Said argued over thirty years ago, "Orientalism" is a European fabrication of "the East", and "the Orient" is shaped by European imperialist attitudes that rely on the Othering of the East to reducible terms. ${ }^{63}$ But in highlighting the visual art of the diasporic individual, lived experience complicates the absurdity of Orientalist discourse, and also allows for a sociological understanding of how community and belonging are made across the diaspora. This last point is one that Nadine Naber

\footnotetext{
${ }^{63}$ Edward Said. Orientalism. (New York: Vintage Books, 2003).
} 
believes has the possibility of decolonizing Arabness or rearticulating Arabness beyond Orientalism - a concept I will interrogate and expand upon in a subsequent analysis on the performativity of racial identity. The artwork of both these diasporic artists then is transcending dominant concepts of Arabness, putting forth new visions of identity and cultural belonging. 


\section{CHAPTER THREE}

\section{Queering Middle Eastern Contemporary Art and its Diaspora}

Current literature engaging with Middle Eastern homosexuality is focused on issues of Modernity, multiple Modernities, and the West's claim to Modernity. Modernity ${ }^{64}$ as a time period signals social, political, and historic conditions (typically urbanization, mass production, democratization, etc.) at the end of the nineteenth-century and early twentiethcentury. Characteristically within Eurocentric writings of art history, such as that of Paul Wood, Western Modernity was seen as the pinnacle of the advancement of modern industrial societies and social progress. ${ }^{65}$ While Wood tries to foster dialogue with art produced in contact zones and the impact of the exotic Other on the rest of Europe, he still writes in unwavering favor of European exceptionalism and for an imperialist account of history. While paying lip service to the fact that "European knowledge of the wider world was partial, and unmistakably framed by a growing sense of European superiority," ${ }^{\prime 66}$ such criticism is lost in his dismissive reading of Orientalist visual art. Furthermore, overarching statements that claim "it was the art of Manet and his followers, the impressionists, that definitively established the connection between modern subjects and modern techniques" reproduce the same Eurocentric canon that relegates the Other as marginal/derivative, and ignores the Egyptian modernist painter Mohamed Nagy (among countless other non-

\footnotetext{
${ }^{64}$ Not to be confused with Modernism, which points to the cultural trends that respond to the conditions of Modernity in a myriad of ways, such as modern art.

${ }^{65}$ This is evident in his book, Western Art and the Wider World (Chichester, West Sussex: John Wiley \& Sons Ltd, 2014)

${ }^{66}$ Paul Wood, Western Art and the Wider World (Chichester, West Sussex: John Wiley \& Sons Ltd, 2014), 143.
} 
Western artists) who visited impressionist painter Monet in Giverny in 1918, and later exhibited in the Paris Salon. ${ }^{67}$

Scholars such as Walter Mignolo, Irene Silverblatt and Sonia Saldivar-Hull are but a few who question this new imperial structure of power, and examine how Modernity can be a method to colonize social and cultural practices in the name of Western advancement. They argue that Modernity is formed by European philosophers, academics and politicians, and that modernity involves the colonization of time and space in order to create a border in relation to a self-determining Other and its own European identity; in this way, Europeans colonized the world and built on the ideas of Western civilization and modernity as the endpoints of historical time, and Europe as the center of the world ${ }^{68}$ Mignolo also goes as far to say that coloniality ${ }^{69}$ is constitutive of modernity, and there is no modernity without coloniality. ${ }^{70}$ Ultimately, the literature on Arab sexualities contends that the West created a discourse around sexuality that the Middle East never had, leading to the notion of homocolonialism, imperialist ideologies in the name of sexual tolerance. As a push against colonial forces and imperialism, homosexuality in the Middle East was then made into an illegal identity category, an identity category that I argue did not exist prior to this increased contact with Western explorers and travelers.

\footnotetext{
${ }^{67}$ Saeb Eigner and Zaha Hadid. Art of the Middle East: Modern and Contemporary Art of the Arab world and Iran (London: Merrell, 2010), 19.

${ }^{68}$ Walter Mignolo. The Darker Side of Western Modernity: Global Futures, Decolonial Options. (Durham: Duke University Press, 2011).

${ }^{69}$ This is a term that Mignolo uses in his writing, and signals modernity's elaborate façade of "civilizing" as its necessary foundation in the terror-logic of imperial rule. Page X of preface in: Walter Mignolo, The Darker Side of Western Modernity: Global Futures, Decolonial Options (Durham: Duke University Press, 2011).

${ }^{70}$ Walter Mignolo. The Darker Side of Western Modernity: Global Futures, Decolonial Options (Durham: Duke University Press, 2011), 3.
} 


\section{MODERNITY AS IMPERIALISM}

With the scholars unpacking the impacts of Western Modernity and its legacy,${ }^{71}$ much attention is given to issues of language and translation — so simply "speaking" about Arab homosexuality has its pitfalls. For example, the Arabic word for sex, jins, appeared sometime in the early twentieth century and held the meaning of both biological sex, and national origin. ${ }^{72}$ The word, derived from the Greek genus, had existed in Arabic since ancient times, holding biological meanings of type, kind, and ethnolinguistic origins. As late as 1870 , its connotation of sex and nationalism had not yet come into usage. ${ }^{73}$ Similarly, in the 1950s translators of Freud coined the unspecific term for sexuality, jinsiyyah, which also means nationality and citizenship. Here, post-contact and under the auspices of colonialism, we see how the Arabic language changed to include sexuality discourses as a part of identity discourses, many times indistinguishable from one another. The conflation of sex, sexuality, nationality, and biology introduces an identity discourse that did not exist in the Arabic language prior to the late nineteenth-century. This marks a significant shift in local identity scripts being colonized by Western Modernity narratives,

\footnotetext{
${ }^{71}$ Kathryn Babayan, Afsaneh Najmabadi, Dina Al-Kassim, Valerie Traub, Rahman Momin, Joseph Massad, Samar Habib, and Jocelyn Scarlet are only a handful of scholars working to unpack the baggage of Western Modernity and its colonial implications. Further discussion on the colonial models they engage with are included in my literature review at the start of this thesis.

72 Jins' connotation with Nationalism as I am using here had not come into usage until the mark of Western Modernity. It is worth noting however that the etymology of the term draws biological and taxonomical relations to species, origin, sort, and kind. Nationalism in the more contemporary notion of national identity is the later meaning of $j i n s$ and came to be incorporate during this time period.

${ }^{73}$ Joseph Massad. "Re-Orienting Desire: The Gay International and the Arab World." Public Culture. Volume 14 (2). 2002: 371.
} 
erasing with it the previously fluid gender norms. This is relevant when looking at surviving Middle Eastern and later Islamic literature from the fourth to thirteenth century which narrate examples of homo-social relations and gay desire, none of which illustrate "gay" as existing as a stable identity. Discussing the homoerotic liaisons between the Mamluk elite in late medieval Egypt and Syria, Everett Rowson states that the public expression of homoerotic sentiments (especially in poetry) was fully sanctioned by Islamic societies both before and during the Mamluk period of the thirteenth and fourteenth centuries, but too-public homosexual behavior was not condoned. ${ }^{74}$ Likewise, Traub illustrates that Arab-Islamic texts speak frequently about the androgynous beauty of beardless boys and are explicit about anal intercourse and fellatio. ${ }^{75}$

In establishing the complexities of terming a historically Arab homosexuality, even the term Middle East becomes highly problematic as we try to decolonize identity narratives, as the term was a geopolitical and military description coined by European cartographers at the turn of the twentieth century in the rise of oil explorations. ${ }^{76}$ The issue then becomes: how can we speak about a homosexuality that did not exist as an identity, about a place

\footnotetext{
${ }^{74}$ Everett Rowson, "Homoerotic Lisaisons among the Mamluk Elite in Late Medieval Egypt and Syria." in Islamicate Sexualities: Translations Across Temporal Geographies of Desire., eds. Kathryn Babayan and Afsaneh Najmabadi (Cambridge, Mass: Center for Middle Eastern Studies of Harvard University, 2008), 204-238.

${ }^{75}$ Valerie Traub, "The Past is a Foreign Country? the Times and Spaces of Islamicate Sexuality Studies," in Islamicate Sexualities: Translations Across Temporal Geographies of Desire. , eds. Kathryn Babayan and Afsaneh Najmabadi (Cambridge, Mass.: Center for Middle Eastern Studies of Harvard University, 2008), 24.

${ }^{76}$ Kathryn Babayan and Afsaneh Najmabadi, Islamicate Sexualities: Translations Across Temporal Geographies of Desire (Cambridge, Mass: Center for Middle Eastern Studies of Harvard University : Distributed by Harvard University Press, 2008), ix.
} 
that is colonially termed, in a language that was created to stabilize unstable Arab sexualities?

Given the colonial hangovers of Modernity narratives discussed earlier, even notions of labeling are increasingly complicated when considering non-Western examples of homo-social couplings. As Tarik Bereket and Barry Adam's research on gay identities in Turkey contends, the contemporary concept of gay as an identity category is commonly generational, classed, and is dependent on a certain social status and education level. However in male sex with men relations, terms like active and passive, which dictate how the individual performs their masculinity, are more socially relevant categories at the local level. ${ }^{77}$ These ideas of masculinity scripts are in line with Judith Butler's notions of performativity, reiterating a type of masculinity that serves to define an identity as either active or passive; the passive subject refuses to take on the active image of the hypermasculinized, as it conflicts with his identity script as passive. The subtle signs exchanged between an active and passive individual in public and social settings are an example of the codification present in some Youssef Nabil's photographs. Accordingly in this chapter, I aspire to uncover the visual language that speaks about local sexuality scripts to both the Arab world and the diasporic community in North America, a language that can help navigate these murky waters of subtlety and codification.

\footnotetext{
${ }^{77}$ Tarik Bereket and Adam Barryd, "The Emergence of Gay Identities in Contemporary Turkey." Sexualities 9, no. 2 (2006): 131-151.
} 


\section{CODIFICATION AND SUBTLETY}

While in other chapters of this research I have examined Youssef Nabil's photographs in the context of nationalism, exile, migration and diaspora, I want to focus this analysis on a series of seemingly homoerotic and subversive photographs that transcend our current understanding of Middle Eastern sexuality. This discussion will have us thinking about Arab homo-sexualities in terms of desire and alternative masculinities rather than Western notions of homosexuality predicated in "born this way" campaigns. These campaigns are not conducive to understanding broader issues of homocolonial discourses, and how queer Arabs living in the West experience their sexuality. With this said, I do not want to reduce the Western model of homosexuality to an essentialist and colonial ruse. Western scholars such as Judith Butler argue that gendered identity is an ongoing performance rather than a predetermined genetic entity. It is important to understand here that neither model categorically fits the gendered or sexual identity of the diaspora, nor do they account for the cultural dichotomies negotiated by non-Western subjects in the West.

My intent is to engage with how the Middle Eastern diaspora in North America experiences the impact of homo-colonialism in a less historiographical discussion, and one more rooted in sociological ideas of gender, nationalism, and sexuality, as well as the triangulation of identity and oppression that could arise at their intersection.

In the first chapter, I outlined the formal elements Nabil employs in his artistic practice. His photographs comprising of hand-tinted silver gelatin prints become once 
again a site of relevance as we recount the history of photography, and the effect hand tinting has to alter the reality of his photographs. While daguerreotypes amazed the world in the 1830 's, having images appear in full colour rather than the rich sepia tones of early photographs became inescapable. In response, photographers attempted to add colour by hand-tinting the developed photographic image in a series of "colourizing" techniques referred to as "overpainting." attempt to produce an image that best mimicked realism, and best reproduced an authentic representation of reality. Thus far, I have argued that Youssef Nabil hand paints his photographs to create an illusory realm within his photographs in a way to alter and control the representation of his identity. Building on this point, I argue that it is also a method of re-writing Western scripts of Modernity to introduce local narratives of Middle Eastern sexuality.

I begin this analysis with an artwork that references the history of Arab representation and homo-Orientalist imagery. This Orientalist method of representation depicts Arab men as sexually perverse, overly sexual, and is a way of stabilizing their unstable identity categories. It is a method of representation where Arabs and Muslims can only be objects of European scholarship but never its subject or audience. In Malik Sleeping, Paris, 2005 (Figure O) we get a post-Orientalist depiction of Malik, who functions as both the subject and object. Here, traditional depictions of the European odalisque are subverted, and gender norms are also reimagined. The male figure is not nude, but his pants are lowered

\footnotetext{
${ }^{78}$ Patsy G. Watkins "The Painted Photograph, 1839-1914: Origins, Techniques, Aspirations” in Journalism \& Mass Communication Quarterly, Spring, 1997, Vol.74(1): 217.
} 
suggestively. His back faces the audience, which allows us to objectify him and literally penetrate him with our gaze. This passive pose is not in keeping with traditional depictions of men in the history of visual culture, where men are usually dominantly placed in the frame and assert eye contact with the viewer. Here, this idea of subverting gendered expectations has parallels to the larger scope of Middle Eastern homosexual desire and the re-conceptualization of sexual identity. As discussed previously in the case of Turkey, contemporary homosexual identity is not commonly labeled as gay identity; in fact it is the minority of men who have sex with men that actually identify as gay. However they have adopted an active versus passive model of identity and masculinity manifested in unspoken codes and signs. What I want for us to think about then is why this image is perceived as homoerotic? What is it about this man's manifestation of his masculinity that is not in keeping with Western notions of masculinity, which have a very specific history of the hyper-masculine Marlborough Man and cowboy genres of representation? And what deviation of masculinity is present here that then re-codifies this male body as being homoerotic? These are larger issues that I intend to address in future research projects, and only begin to address in this analysis.

With this codification of masculinity in mind, I would like to discuss the process of meaning making in interpreting both masculinity and homosocial desire through Nabil's photographs. In looking at Ahmed in Djellabah, New York, 2004 (Figure P) and Ali in Abaya, Paris, 2007 (Figure Q) we have two depictions of men: one wearing an abbeya (Ali), which is traditionally used in prayer, and the other a gallabaya (Ahmed), which is traditionally worn around the house or as outerwear. These distinctions are relevant, for the 
codification of masculinity and homoeroticism lies in these details. Ironically, the gallabeya, which signifies that this is a private scene, is almost less eroticized than the abbeya which would be for public prayer. The photograph of Ali has us focusing on the hairy chest and the slit in the abbeya very teasingly opened to the man's midsection (and even lower) to accentuate an erotic tension. While the insinuating nature of the man in the gallabeya sprawled on the bed with his legs open to us certainly has its implications, I want us to think about how sexuality is experienced in the public and private spheres, and the religious implications when these spheres intersect. Here, I am suggesting that the private becomes public, and we have a de-privatization of homoerotic codification, which is something very different than when we look at historic representations of same-sex desire in Middle Eastern literature. I focus on the geography of the diaspora in other chapters of my analysis, and it will not be overlooked here. The fact that these photographs were taken in both New York and Paris (and the artist wants us to know this by including the locations in the title), further implicates how the diasporic subject experiences their sexuality in the liminal and in-between identity category discussed earlier.

Emphasizing the geography of diasporic identity once more, the bulk of Nabil's photographs that I analyze are taken outside of Egypt. However I want us to once more look at how the narrative shifts and changes when the location is Egypt. In What Have We Done Wrong, Cairo, 1993, (Figure R) two men sit ambivalently on a bed, avoiding each others' gazes and sit in deep contemplation, if not sorrow. While a sexual narrative is not explicit, the deep psychological turmoil of a homosexual encounter is at the forefront of 
this photograph. The main thing I want us to focus on here is the location, What Have We Done Wrong takes place in Cairo.

Let us juxtapose this narrative to Not Afraid to Love, Paris, 2005 (Figure S). ${ }^{79}$ The sexual assertiveness present in this photograph is most certainly distinguished from the fear and trauma experienced in the Cairo representation. Here, in the Paris narrative, the colours are much brighter and much more vibrant than the subdued pink and dark blacks in the Cairo picture.

While What Have We Done Wrong, Cairo has an ominous underground feeling of hiding and shame due to the colour palette, lighting, and dramatic tension, Not Afraid to Love, Paris uses colour to imply stability and comfort. Even though both figures are not gazing at each other, the tension is relieved. It is because of this juxtaposition that the subversive nature of these photographs is subtle and seemingly problematic. Each image reflects the general attitudes of the locations for which they were named. Cairo depicts a sense of shame and wrongdoing, while Paris implies freedom and a sense of peace. Each image seemingly adopts the homonormative tone of its cultural geography. Rather than reduce these complex images as being a part of what Joseph Massad calls the Gay International, a mission of homocolonialism and Western exceptionalism, I argue that by expressing and representing the real impact and emotion surrounding these cultural attitudes, Nabil is reverting back to local identity narratives and codes of masculinity and desire.

\footnotetext{
${ }^{79}$ Interestingly, this image illustrates the cover of Brian Whittaker's book, Unspeakable Love: Gay and Lesbian Life in the Middle East. (Berkeley: University of California Press, 2006).
} 
Nabil's photographs show the homosocial relations visible in the pre-Modern social couplings in the Middle East (as outlined earlier in the surviving Middle Eastern and later Islamic literature from the fourth to thirteenth century, narrating examples of homo-social relations and gay desire). These local narratives lie in the disidentification of normative Queer identity as it exists in the West, and instead adopt a queerness rooted in male relations with men rather than predicating an identity category. This fluidity allows for the subjects in Nabil's photographs to function outside the prescribed assumptions associated with Western queerness, and rather resembles the sexuality scripts that existed precolonialism. This is not to say that colonialism completely erased the local sexuality narratives outlined by Babayab, Najmabadi, Habib, and many others, and it does not assume an unproblematic notion that those sexuality scripts existed at a pure state. Bearing in mind Homi Bhabha's writings on hybridity and the location of culture, we can assume that a pure and uncontaminated sexuality script never existed in the Middle East, even before colonization. What I suggest is to highlight how artists like Youssef Nabil are using photography to illustrate the local sexuality scripts that have become predominantly and overwhelmingly the Western Queer narrative. This narrative is steeped in identity formations that erase the fluid sexuality as seen in the Mamluk Elites of late medieval Egypt, or the homosocial female companionship in seventeenth-century Safavid Iran. ${ }^{80} \mathrm{I}$

\footnotetext{
80 This is in reference to Kathryn Babayan, "'In Spirit We Ate Each Other's Sorrow': Female Companionship in Seventeenth-Century Safavid Iran," in Islamicate Sexualities: Translations Across Temporal Geographies of Desire., eds. Kathryn Babayan and Afsaneh Najmabadi (Cambridge, Mass: Center for Middle Eastern Studies of Harvard University, 2008), 239-274. Due to the subject matter of Youssef Nabil's photographs, I do not engage with female desire or lesbian relations in this particular analysis. Babayan's text, however, illustrates another example of fluid identity formations present in Islamicate regions prior to colonization.
} 
argue that the revival of these local sexuality scripts is seen in Youssef Nabil's homoerotic photography, and that they have an openness to reject the rigidity of a Western Queer identity category. Rather, Nabil's photographs illustrate homosocial relations void of the mandatory homosexual identity that, I have argued, is a product of Western Modernity.

The display of male intimacy as relating to homosocial couplings rather than a gay sexual imagery helps illustrate the complicated and immensely subversive nature of manifesting the sexuality of the diaspora in a visual language. In Rashid With a Shisha in his Mouth, Paris, 2004 (Figure T), we have a scene of a topless young man reclining in shorts in the act of smoking a shisha, an Egyptian water pipe. Once again rejecting a mandatory homosexuality and instead illustrating a moment of homosociality, Rashid is demonstrating a masculinity that is extremely vulnerable and arguably passive. With the seductive insinuation of Rashid smoking on the shisha pipe, we are left with a culturally specific image of a young man engaging in the highly normative act of smoking a shisha with his friend. The vulnerability adds to a reading of the photograph as being homoerotic as it conflicts with the machismo that has been internalized in Western masculinity. With the anomalies of male relationships and of male bodies, Nabil is able to allude to a fluid same-sex desire without labeling the subject of the scene as homosexual. This distinction is essential as it loosens the grips of the totalitarian gay identity that has been associated with Western queerness, and makes it possible for local sexuality scripts to be both vocalized and visualized.

The crux of this argument lies in the Middle Eastern Diaspora in North America using these local identity narratives of alternative masculinities and codification in a transnational setting. In this way, the localization of homosexual desire even in Western 
settings such as Paris can further help us understand these local networks of identity on a more global scale, and how the diasporic subjects in North America frame desire using narratives that derive from their cultural heritage. What I want to see is whether we can reach a narrative that works beyond oppression versus acceptance, and instead examines a negotiation of diasporic sexuality by incorporating different sociological strategies to help self-identification categories be less dichotomous.

\section{LETTING IN}

Narrative psychologist Sekneh Hammoud-Beckett has coined the term "letting-in" as a way to negotiate and alter Western narratives of coming out. This is a process that she describes as the conscious and selective invitation of people into one's "club of life" as she puts it. ${ }^{81}$ Here, letting-in is a process that is highly relevant to the diaspora, as it is a way to alter perceptions of what it means to live a truly gay life, and falsifies the Western need to become more visible in order to be complete. Nabil's artworks discussed thus far exemplify networks of communications that are different from the global-to-local homocolonial imposition of gay identity that most contemporary literature on the topic focuses on; instead, I argue that these local networks are let-in by homosexual, queer, maledesiring subjects in North America, and Middle Eastern diasporic subjects are then creating an alternative coming out narrative and identity script than the inscribed Western model.

\footnotetext{
${ }^{81}$ Sekneh Hammound-Beckett, "Azima Ila Hayati- an Invitation in to My Life: Narrative Conversations about Sexual Identity." International Journal of Narrative Therapy and Community Work 2007, no. 1 (2007): 29-39.
} 
The visual reading of Rashid With a Shisha in his Mouth, Paris, 2004 can illuminate how local instances of homosociality cite traditional sexuality scripts, and reject the Western queer identity narrative that becomes exclusionary in non-Western contexts. These photographs become just one example of how local networks of identity are transmitted through visual language, and alternative sexuality scripts are written. ${ }^{82}$

Rahman Momin argues that Islamophobia and homophobia reinforce one another through a process of triangulation. Explaining the lack of belonging to either a Western or Arab sexuality discourse, Momin claims the Muslim community sees a gay Muslim as an unviable identity, stemming from homophobia and larger systemic issues of racism in our post-9/11 societies. Similarly, Western gay communities also see the gay Muslim as an unviable identity due to Islamophobic and neo-Orientalist discourses that are used to Other and isolate Arab narratives in themes of terrorism and social oppression. ${ }^{83}$ With the unquestioned assumption of inherent homophobia within an Arab identity, the Western gay

\footnotetext{
${ }^{82}$ While the dominant way art history has been written contends that all non-Western art be compared and drawn from Western examples, it does sometimes prove valuable to take the art historical narrative within a more global context. To illustrate my point on subtlety and the difference between a homosociality and an overt homosexuality, we can compare American photographer Robert Mapplethorpe's photographs (Figure U). The subtlety and identity nuanced within Youssef Nabil's photographs are nowhere to be seen in the vivid depictions of gay pleasure, BDSM, and gay sex. Avoiding value judgments on either sets of artwork, it is necessary to highlight the different visual strategies seen in the American gay art movement, and contrast these strategies with the subtlety and strategic identity shifts present in contemporary photography of the Middle East and its diaspora. While I will not touch upon the work of John Ibson in this project, his writing on American photography before the Civil War in 1950s shows a homosociality similar to that of the male relationships found in the photographs of Youssef Nabil. These mid-century American photographs highlight a sexuality script that is closer to the pre-Modern sexuality script we see in the Middle East, one that rejects the totalizing label of gay identity. For future inquiry, see: Ibson, John. Picturing Men: A Century of Male Relationships in Everyday American Photography. Washington, D.C.: Smithsonian Institution Press, 2002.

${ }^{83}$ Rahman Momin, Homosexualities, Muslim Cultures and Modernity (Basingstoke: Palgrave Macmillan, 2014).
} 
community upholds the impossibility of the gay Arab, and fits their existence within preexisting models of Western homosexuality. Here, the gay Arab is stuck in a perilous existence, within an in-between status that makes them an unviable subject in both communities. It is this in-between or liminal existence that the current discourse on Western homosexuality does not account for, and why there is an urgent need to reconceptualize the terms in which we understand homosexual identity and its manifestations in social and cultural texts. Referring to the Middle Eastern diaspora in North America as Arab culture continued in America, ${ }^{84}$ articulating Arabness becomes a difficult battle between rigid versions of the "Arab" and the "American." The dichotomization between the familiar (Europe, the West) and the strange (the Orient, the East) ${ }^{85}$ was reinforced by U.S. media, and interestingly enough by the immigrant community itself in an attempt to distance itself from the media outlets seeking to define them. This leads to an intensification of culture by diasporic communities in North America due to this East versus West, Islamophobic discourse. Arab cultures ${ }^{86}$ in North America then become more culturally conservative and religiously stringent, even more so than their counterparts in the homeland. Nadine Naber recounts that many of her neighbors in San Francisco had more socially conservative understandings of religion, family, gender and sexuality than

\footnotetext{
${ }^{84}$ Rabab Abdulhadi, Evelyn Alsultany and Nadine Christine Naber, Arab \& Arab American Feminisms: Gender, Violence, \& Belonging, 1st ed. ed. (Syracuse, N.Y: Syracuse University Press, 2011).; Nadine Naber, "Decolonizing Culture: Beyond Orientalist and Anti-Orientalist Feminisms" in Arab and Arab American Feminisms: Gender, Violence and Beloning, eds. Rabab Abdulhadi, Evelyn Alsultany and Nadine Naber (Syracuse, N.Y.: Syracuse University Press, 2011), 78 .

${ }^{85}$ Ibid.

${ }^{86}$ This is not only specific to Arab communities, but other immigrant communities also function within a similar paradigm when outside of their homeland.
} 
their counterparts in Jordan. ${ }^{87}$ This conflict has to do with issues of culture and hybridity, their intersection, and how diasporic subjects articulate culture. What I argue is that given the importance of lived experience and firsthand accounts within sociological studies of expatriation, portraits such as those of Youssef Nabil's lend themselves to understanding the transnational experience, and illuminate how culture and nationalism are articulated by the Middle Eastern diaspora in North America. The artworks of Youssef Nabil provide an exceptional case study to understand how culture and identity are navigated through political art production, and how art is used as a means of necessity, and a tool of selfactualization.

The question we need to ask then is how we can work through this predicament of identity without re-inscribing the neo-colonialism of Western gay identity, and ultimately reproducing Orientalist understandings of the East and West divide. How can we work past these harmful representations of trauma, but still reflect the real lived pain experienced by gay transnational subjects? And how can we move towards the possibility for non-viable subjects to become viable, and eventually move towards a place of healing? Theorizing about imperialism and international human rights law, Judith Butler writes that certain lives are not considered lives at all, that they cannot be humanized: their dehumanization occurs at a level that gives rise to a physical violence, delivering the message of dehumanization that is already at work in the culture. ${ }^{88}$ This is how we can begin to define unviable and viable identities: dehumanization lies within the new-Orientalist understanding of Arab

\footnotetext{
${ }^{87}$ Nadine Naber, "Decolonizing Culture: Beyond Orientalist and Anti-Orientalist Femanisms." in Arab and Arab American Feminisms: Gender, Violence and Beloning, eds. Rabab Abdulhadi, Evelyn Alsultany and Nadine Naber (Syracuse, N.Y.: Syracuse University Press, 2011), 81

${ }^{88}$ Judith Butler. "Violence, Mourning, Politics," Precarious Life: The Powers of Mourning and Violence. (London: Verso, 2004), 34.
} 
sexualities within the strict parameters of being sexually stringent and lacking to the sexual models of the West. It is at this site of negation - negation of the local sexual narratives that existed long before contact with the West, negation of models of homosociality that exist today and function within their own local forms - that the gay Arab becomes an unviable subject to both the Western and Arab communities to which they belong. Reviving the local models that existed and continue to exist today, but not conflating them to the Western visibility and coming-out measuring-stick, can result in these Queer Arab subjects becoming viable and living lives void of exile and exclusion in both their cultural and diasporic identities.

Momin has argued that intersectional identities (such as gay Arabs in the West) contribute to a disruption of modernity narratives that underpin Western exceptionalism through queer politics. Here the sheer existence of gay Arabs in Western communities (and even those still living in the Middle East) is a disruption of normative identity in either community setting. I ask how we can bring this discussion of existence to one of codification rather than visibility. While being socially visible or invisible is politically relevant if not integral to our discussion, I want to discuss whether masculinity and gay desire are codified in a visual language that becomes a transcultural way to discuss complex issues such as these and represent a multiplicity of experiences.

Overall, gay Arab societies have existing and subtle networks of expressing sexualities and identities, networks that have changed through discourses of Modernity and Western imperialism. What I find from my research is that Modernity's legacy has not yet erased 
these subtle networks of communications, and in-between subjects are conflicted by adhering to multiple identity narratives from multiple cultural sources. As we see the plight of the Queer Egyptian in What Have We Done Wrong, Cairo, 1993, we can interpret this gloom as the colonial pressure of Western homosexuality and the imperialism of a Queer identity category that actively erases culturally specific sexuality narratives that already existed. With the intimate artworks Nabil produces in Paris, Brooklyn, Harlem, and numerous other locations outside of Egypt, it becomes evident how diasporic identity and sexuality can globally portray the culturally specific local narratives of sexuality. In this way, we can see how local sexuality narratives are not passively being colonized by Western Queer discourse, and instead localized understandings of sexualities are being internalized and conceptualized by the diaspora, as exemplified by Nabil's photographs. With the vulnerable images of Rashid taken in Paris or Ahmed in his djellabah in New York, artworks like Youssef Nabil's can contribute to understanding these local identity narratives, and how they manifest themselves in the lives of diasporic subjects globally. 


\section{CONCLUSION}

In this thesis, I have termed and argued for an Exilic Aesthetic, a visual language that is present and employed by Youssef Nabil. This aesthetic is a way to articulate the complex sociological symbols within an artwork, and to understand their significance to larger themes of migration, articulation of culture, and expatriation. As illustrated using the selfportraits of Youssef Nabil, it is through the strategic language used in the titles, the composition of the portraits, and the fragmentation of Nabil's body that these narrative tools are combined to create an Exilic Aesthetic. They are also a vehicle for understanding larger themes of expatriation and articulating Arabness.

In the second chapter, Complicating the Exilic Aesthetic, I examined the ways in which the geography of diaspora can contribute to an aesthetic function. Using my own artwork as a point of analysis, I outline the anomalies present within my self-portraits and those of Youssef Nabil. In doing so, the Exilic Aesthetic is reinforced as these anomalies allow us to theorize the use of photography as an identity-affirming narrative, contribute to the impact of temporal geographies to the diasporic artist, and problematize narratives of homeland. Examining how an Exilic Aesthetic functions for artists articulating the same homeland from different geographic birthplaces allows for a more nuanced understanding of the diasporic articulation of culture and experience.

Lastly, the third chapter Diaspora and Modernity investigated Middle Eastern homosexuality and focused on issues of Western Modernity to outline the history of sexuality and representation in the Middle East. Here, Nabil's photographs illustrated the codification of Middle Eastern masculinity through a visual language. I have argued that 
his artwork destabilizes homo-colonial discourses of Western Modernity, and provides a narrative of the negotiation of diasporic sexualities that help categories of selfidentification to be less dichotomous. This is done in part by the diaspora in North America "letting-in" such local narratives of homosociality, and re-defining their discourse of sexuality. I highlight examples of this in the seemingly homoerotic portraits of Nabil and his friends where we see a reversion to local examples of homosociality. These photographs reject a compulsory homosexuality, are follow the patterns outlined in the surviving Middle Eastern and Islamic literature, which narrate examples of homo-social relations and gay desire.

Overall, Nabil's visual narrative in his self-portraiture seems to be selfantagonizing, creating a disconnect between language, imagery, and self-representation. This disconnect is used as a tool to create themes of expatriation, and also create a barrier to be experienced by the viewer, a barrier that prohibits a true understanding of Youssef Nabil from his self-portraiture. Complicating the Exilic Aesthetic through the artworks of two diasporic artists is a way to interrogate the naturalization of the dichotomies between "Arab" and "North American" cultures. Rather than articulating Arabness outside of history and under the purview of Orientalist stigma, re-conceptualizing the articulations of Arabness from different diasporic perspectives helps delineate historic narratives of migration and cultural identity. The diasporic articulation of culture is integral to understanding how Middle Eastern and local sexuality narratives can function globally, and are internalized/re-conceptualized by diasporic sexualities in North America. As argued throughout this text, highlighting the visual art of the diasporic individual has the potential to complicate the absurdity of Orientalist discourse, allowing for a sociological 
understanding of how community and belonging are made across the diaspora. By correlating racial identity with performativity, herein lies the possibility of decolonizing Arabness and rearticulating Arabness beyond Orientalism and historically racist representations. My hope is that the visual analyses, theoretical engagement, and critique that this text offers mark an instance of that possibility. 


\section{EPILOGUE}

\section{Identity}

Early in this research project I had contacted Youssef Nabil and his studio in hopes of having an interview with Nabil and also to obtain copyright permissions for publishing this research. When asked to read the Exilic Aesthetic, a chapter based on nationalism and exile, Nabil and his studio were comfortable and pleased with the work. It was in the writing of the last chapter, Sexuality and the Diaspora where this changed, and it was expressed that Nabil and his studio could not support this chapter. Ironically, it was in fact the insistent homoeroticism in Nabil's work that fueled my desire to both interview him and to pursue in depth scholarly research into his body of work. This discomfort and rejection of being labeled as a "gay artist" was a dilemma that I grappled with through the duration of my research project, trying to respect the wishes of the artist while also maintaining academic integrity.

In conversation with art historian Richard Meyer we discussed a similar experience he had in interviewing figure painter Paul Cadmus (1904-1999). During Meyer's interview with Cadmus in 1992, Cadmus "met each of [his] questions about homosexuality with genteel resistance," 89 and would rather politely change the subject. According to Meyer, it took him almost a year to realize that by changing the subject, Cadmus was in fact answering

\footnotetext{
${ }^{89}$ Richard Meyer. "Identity" in Critical Terms for Art History, ed. Robert S. Nelson and Richard Shiff (Chicago: University of Chicago Press, 1996), 350.
} 
his questions about the homosexual undertones of his paintings. Meyer concluded that there was no space that existed within the professional discourse of American art in the 1930's for any affirmative discussion of homosexuality. When same-sex desire appeared within that discourse, it had to be lodged within the registers of connotation and double entendre, of indirection and insider knowledge. ${ }^{90}$

It is from Meyer's experience with Cadmus that I draw correlation, for homosexuality in the Middle East, whether in Nabil's work or anyone else's, cannot be understood within the coherent, confident terms of what we now call gay identity. I had gotten the message that Nabil did not wish to discuss same-sex desire in relation to his professional work as an artist. While this could do with the political climate of homosexuality, the intrigue comes from the openness to produce and exhibit such subversive photographs. It is for this reason that I theorized Nabil's photographs as being outside the discourse of Western homosexuality and rejecting any gay identity, and rather read the works as a sign of fluidity and openness which mirror the ambiguity in his work. This event calls for more attention to those moments when identity and its visual representation are misaligned, disconnected and uncoupled. As gleaned from Meyer's parallel experience with Cadmus, the problem reminds us that homosexuality has rarely operated at the level of conscious articulation within the history of art. ${ }^{91}$ Dealing with this means attending to homosexual identity as an absence within historical record rather than a fully formed visible category.

\footnotetext{
${ }^{90}$ Richard Meyer. "Identity" in Critical Terms for Art History, ed. Robert S. Nelson and Richard Shiff (Chicago: University of Chicago Press, 1996), 350.

${ }^{91}$ Ibid, 354.
} 


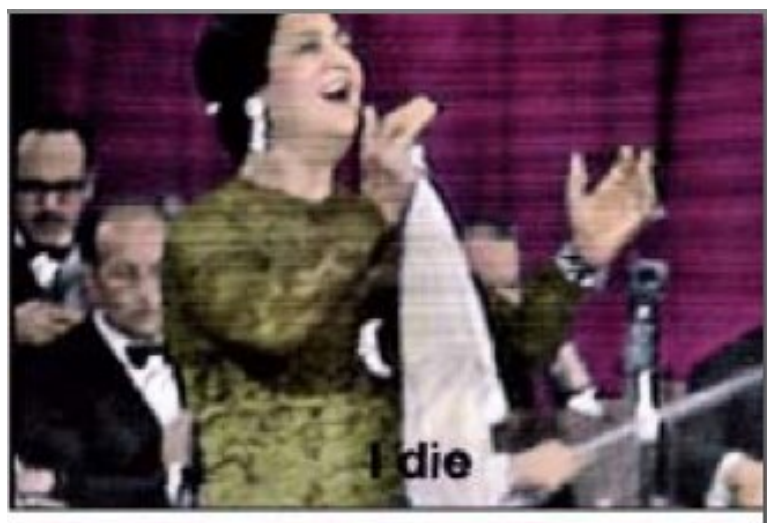

\section{Appendix}
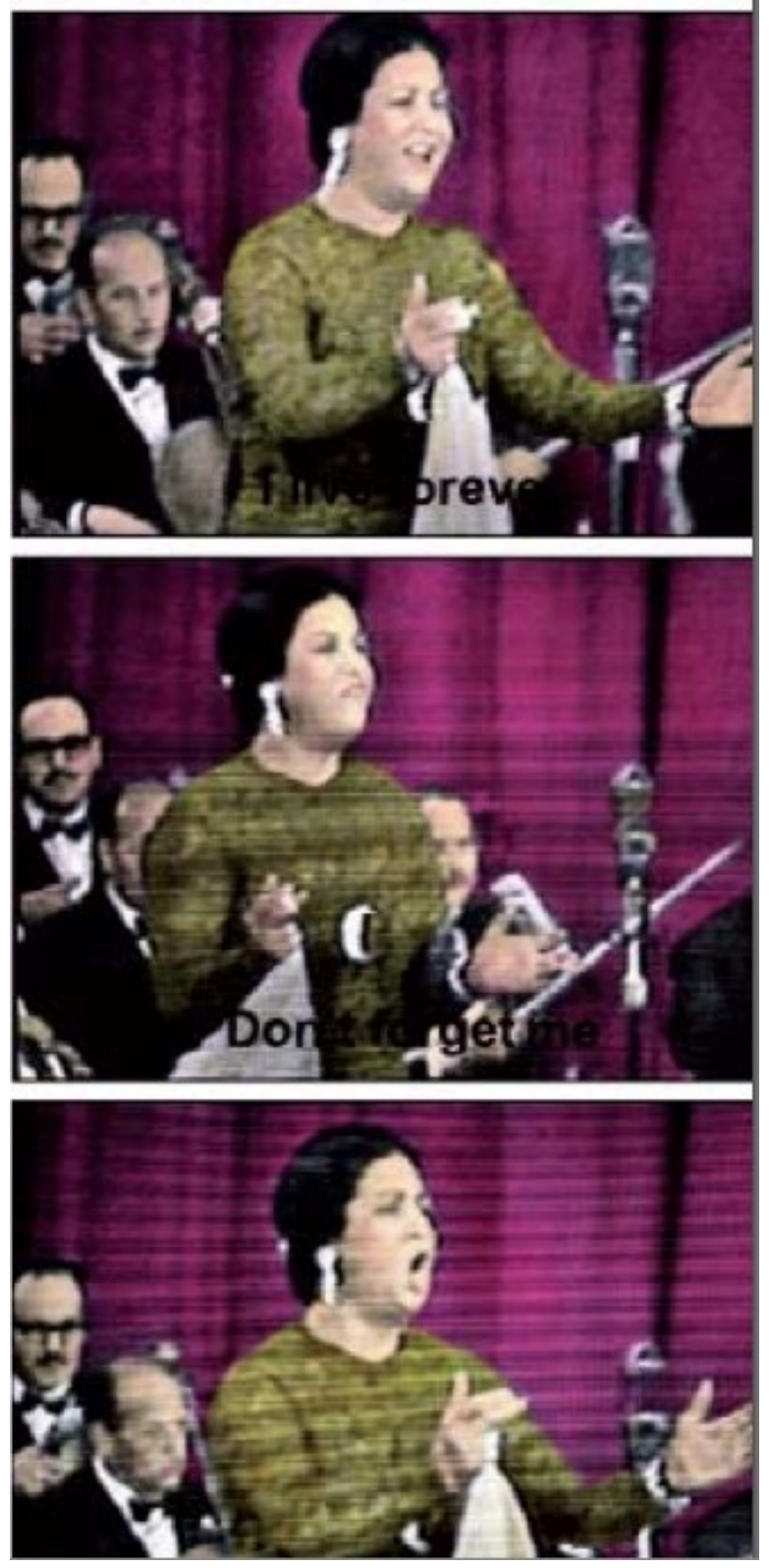

Figure A

STAR, New York, 2007

\section{Youssef Nabil}

Hand coloured gelatin silver print 
Figure B

Never Wanted to Leave-Self-Portrait, Paris 2007

Hand coloured gelatin silver print

Courtesy of the artist and Nathalie Obadia Gallery, Paris/ Brussels.

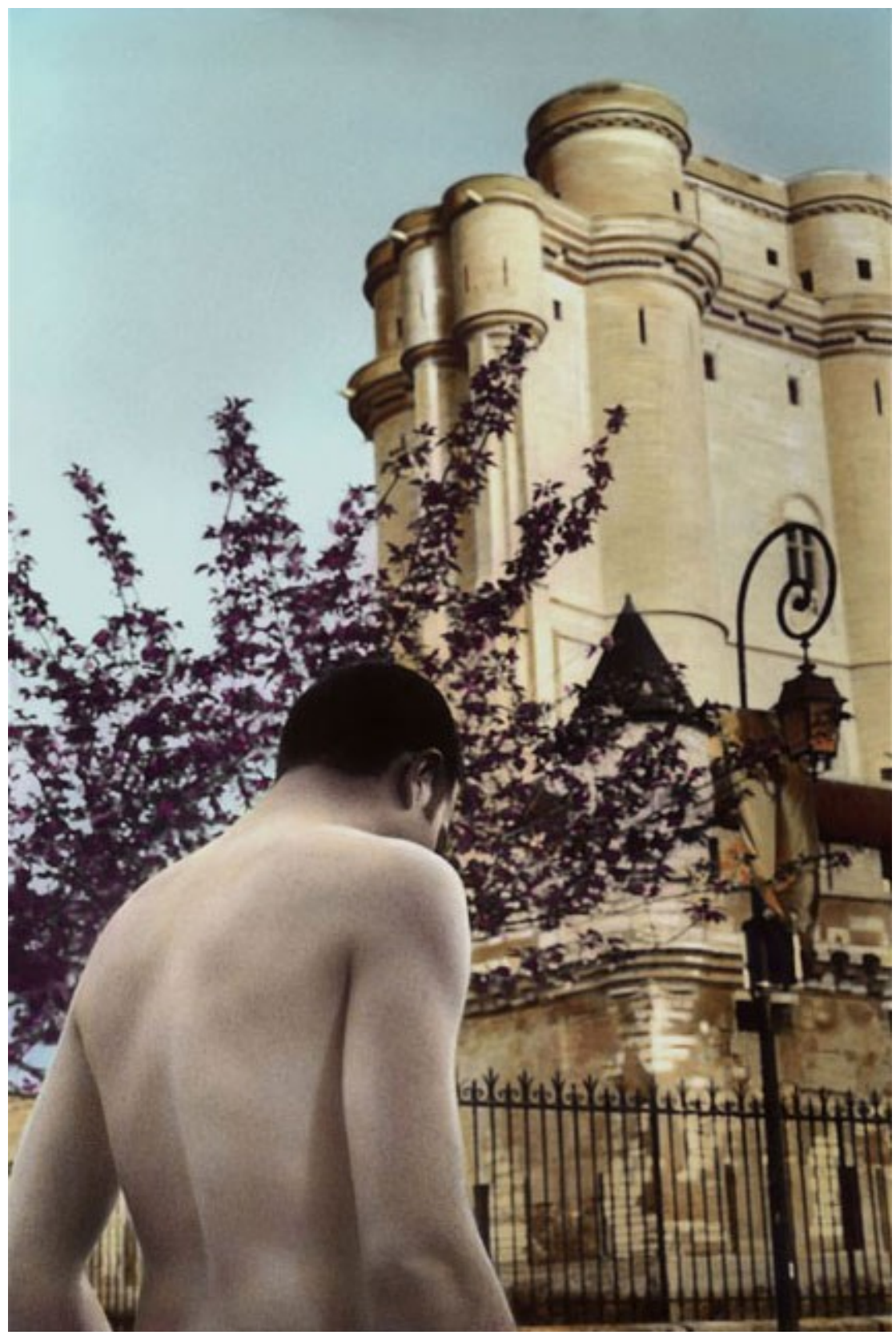


Figure C

Will I Ever Come Again-Self-Portrait, Havana, 2005

Hand coloured gelatin silver print

Courtesy of the artist and Nathalie Obadia Gallery, Paris/ Brussels.

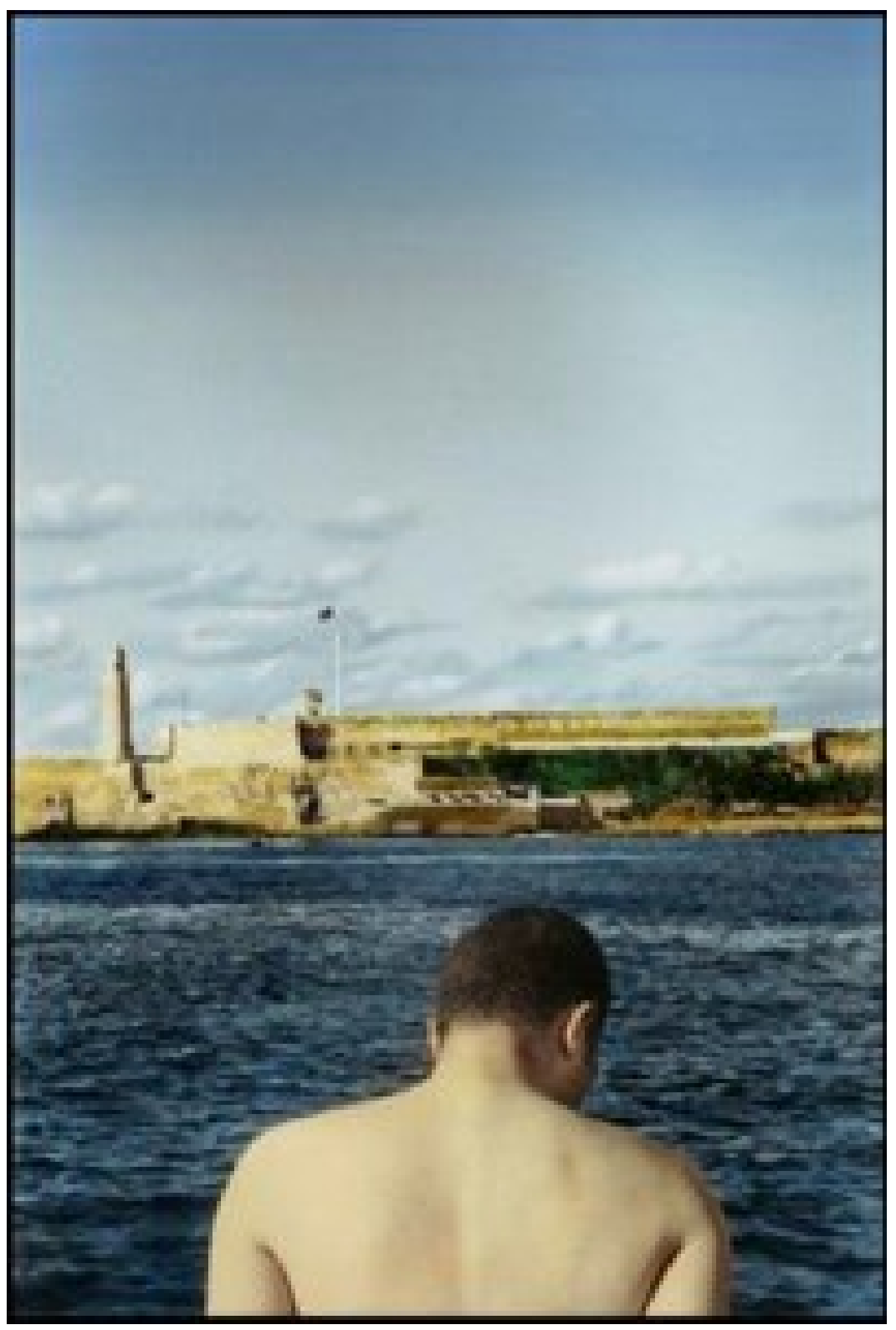


Figure D

I Leave Again-Self-Portrait, Sardinia, 2005

Hand coloured gelatin silver print

Courtesy of the artist and Nathalie Obadia Gallery, Paris/ Brussels.

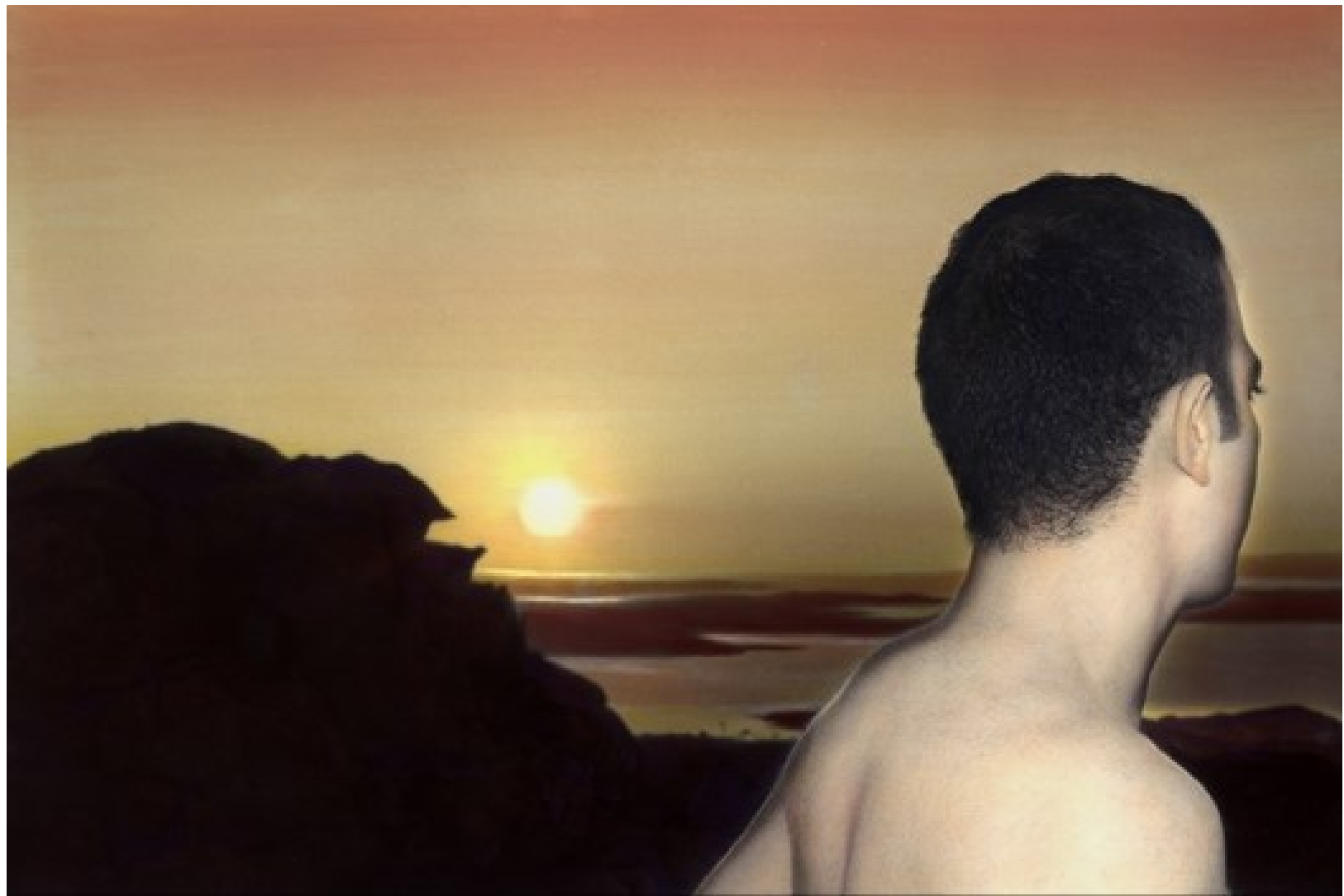


Figure E

My Time To Go-Self-portrait, Venice, 2007

Hand coloured gelatin silver print

Courtesy of the artist and Nathalie Obadia Gallery, Paris/ Brussels.
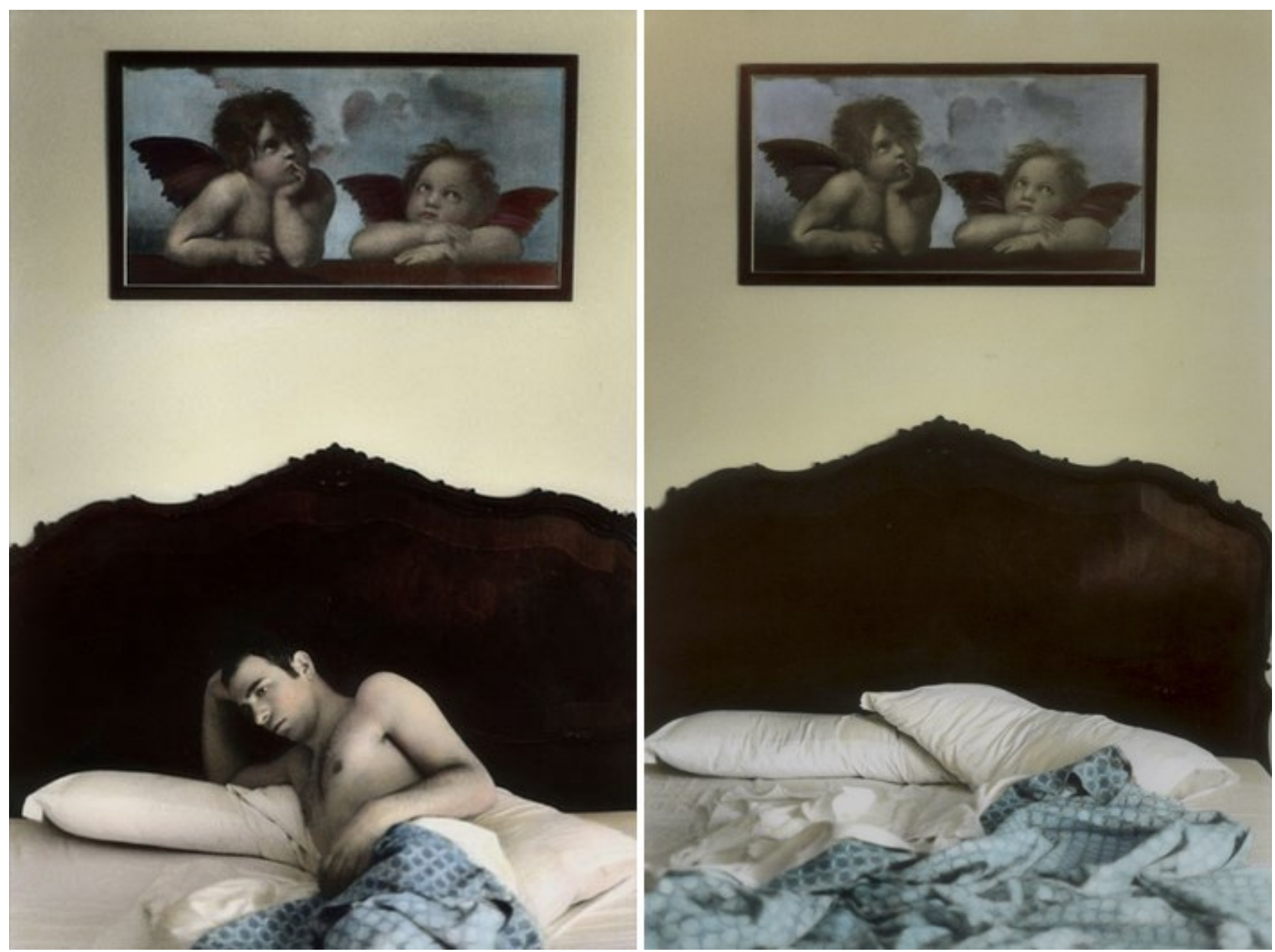
Figure F

Self-Portrait with Roots, Los Angeles, 2008

Hand coloured gelatin silver print

Courtesy of the artist and Nathalie Obadia Gallery, Paris/ Brussels.

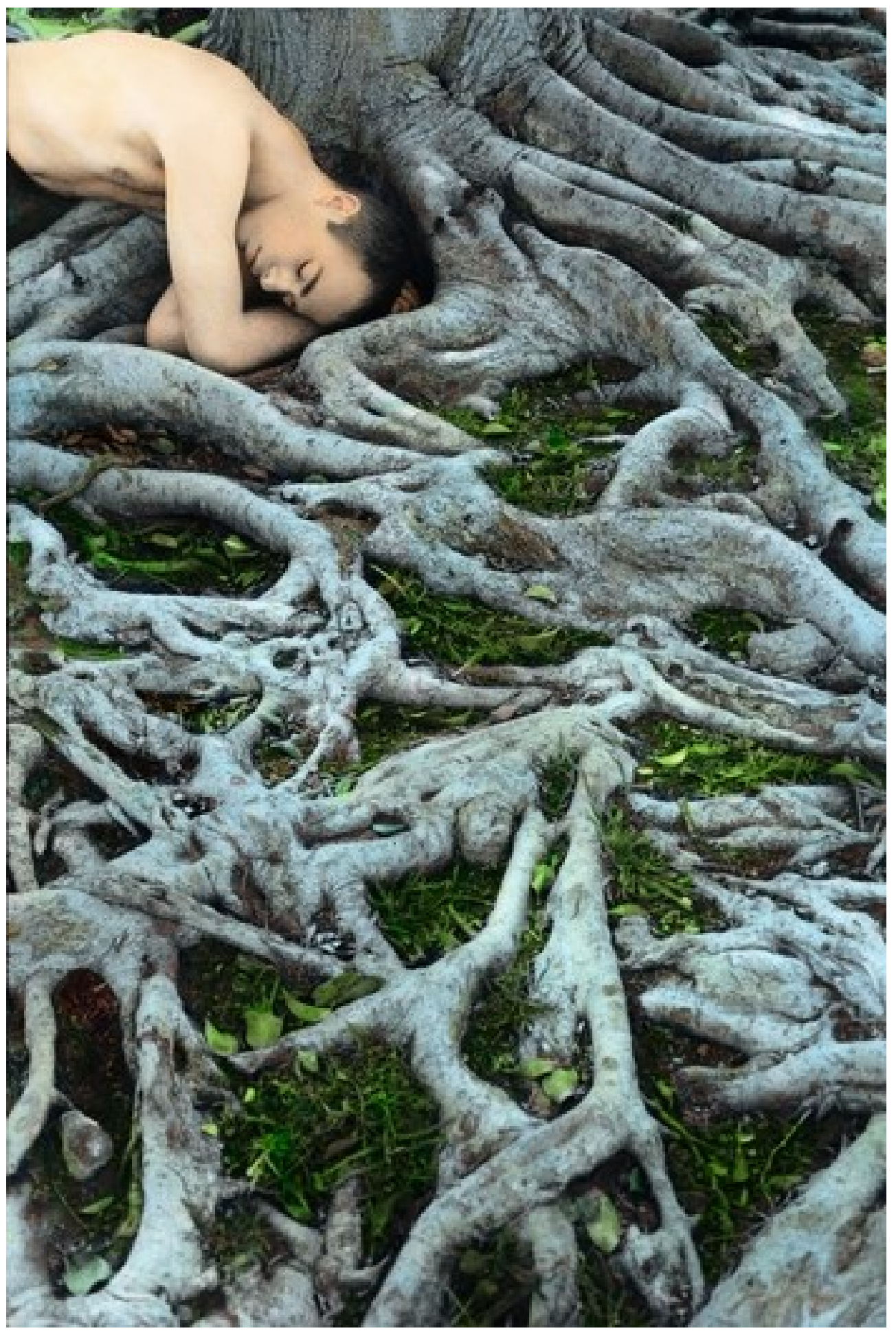


Figure G

Andrew Gayed

Freedom, 2011

Black and White Inkjet Print on Archival Photo Paper, 42x42 Inches

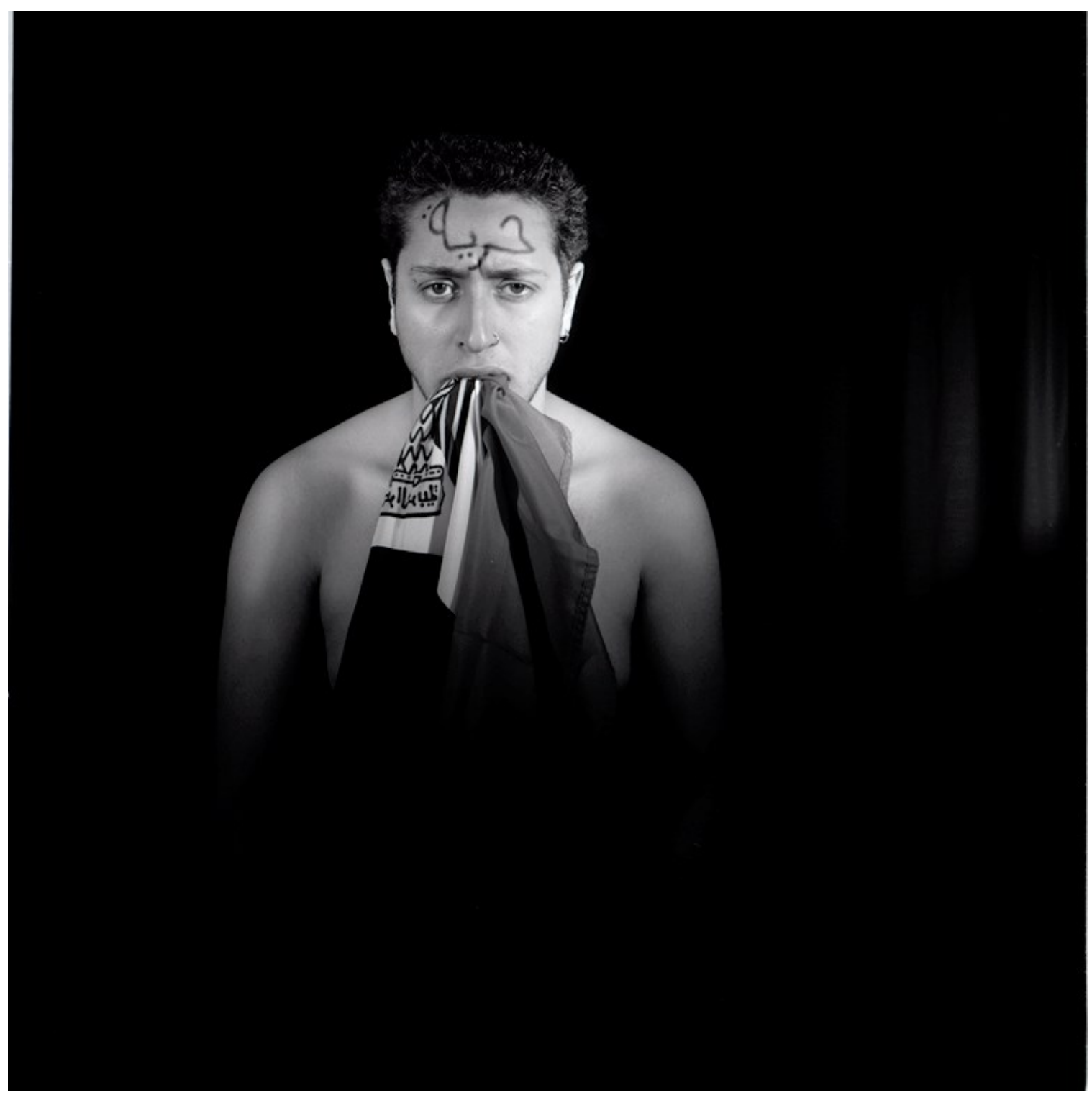


Figure H

Film stills from Sacrifice, video performance. Andrew Gayed. 2013.

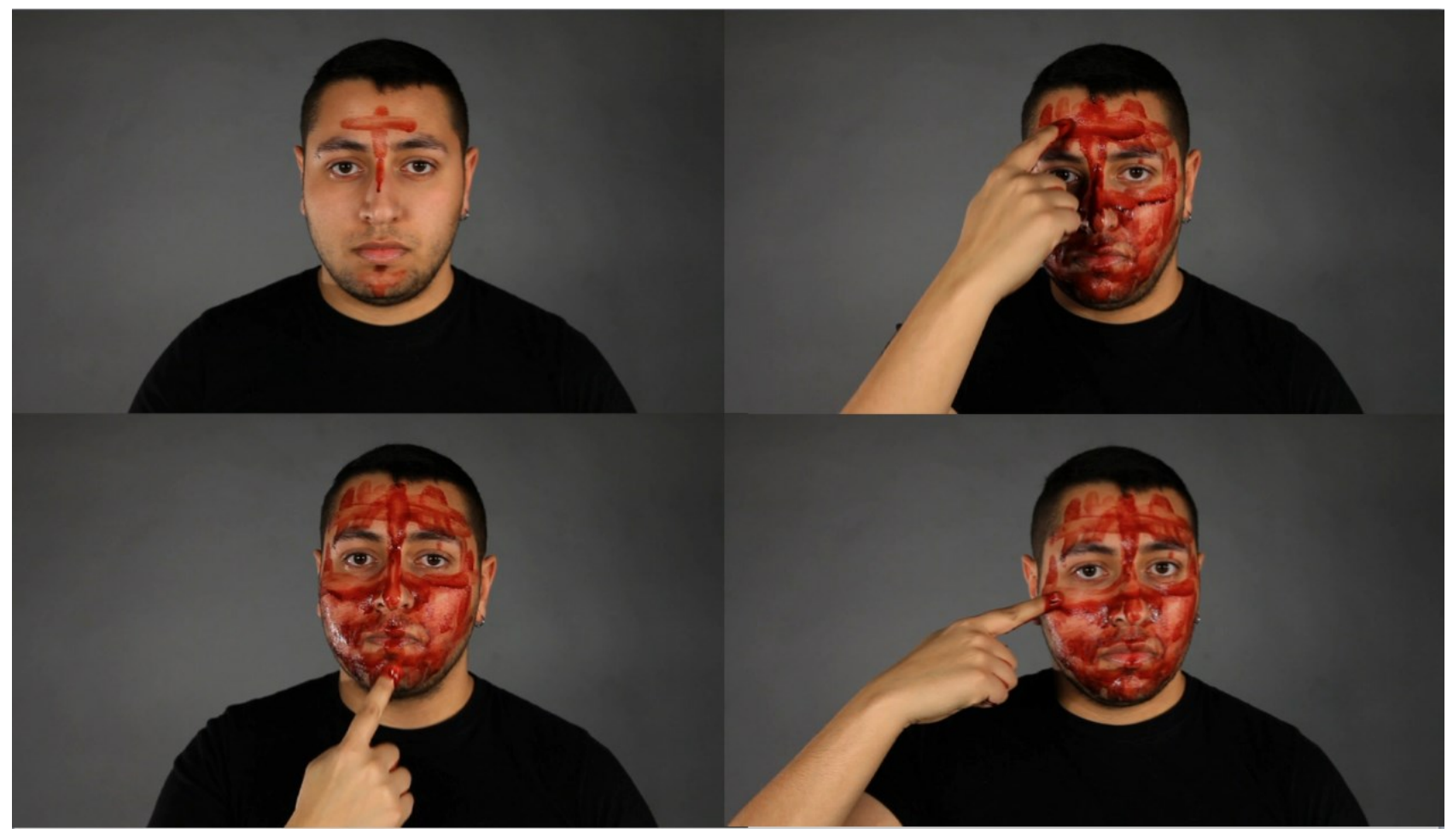


Figure I

Film stills from Baptism, video performance. Andrew Gayed. 2013.

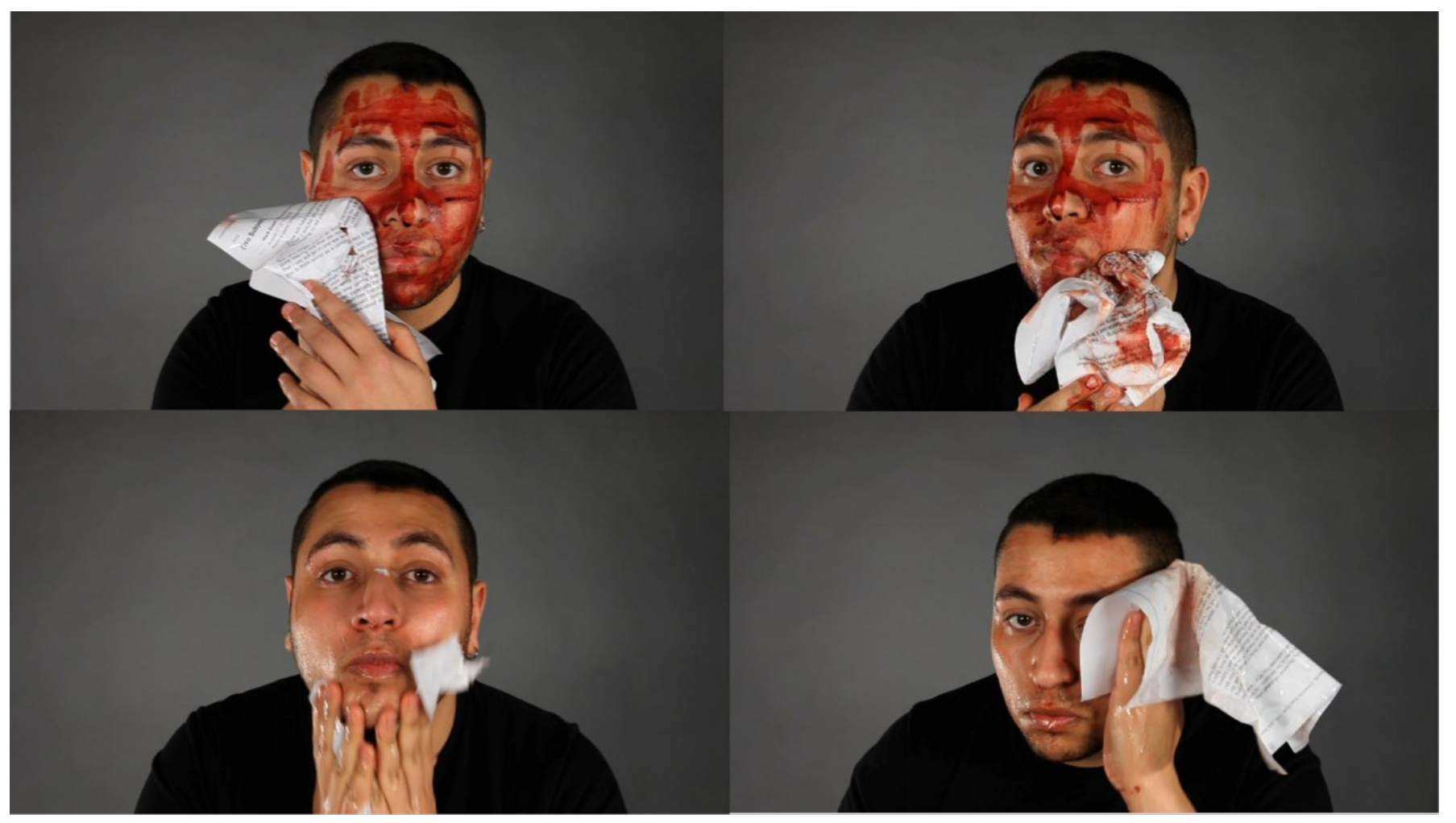


Figure $\mathrm{J}$

Youssef Nabil. Say Goodbye, Self Portrait, Alexandria 2009. Hand coloured silver gelatin print.

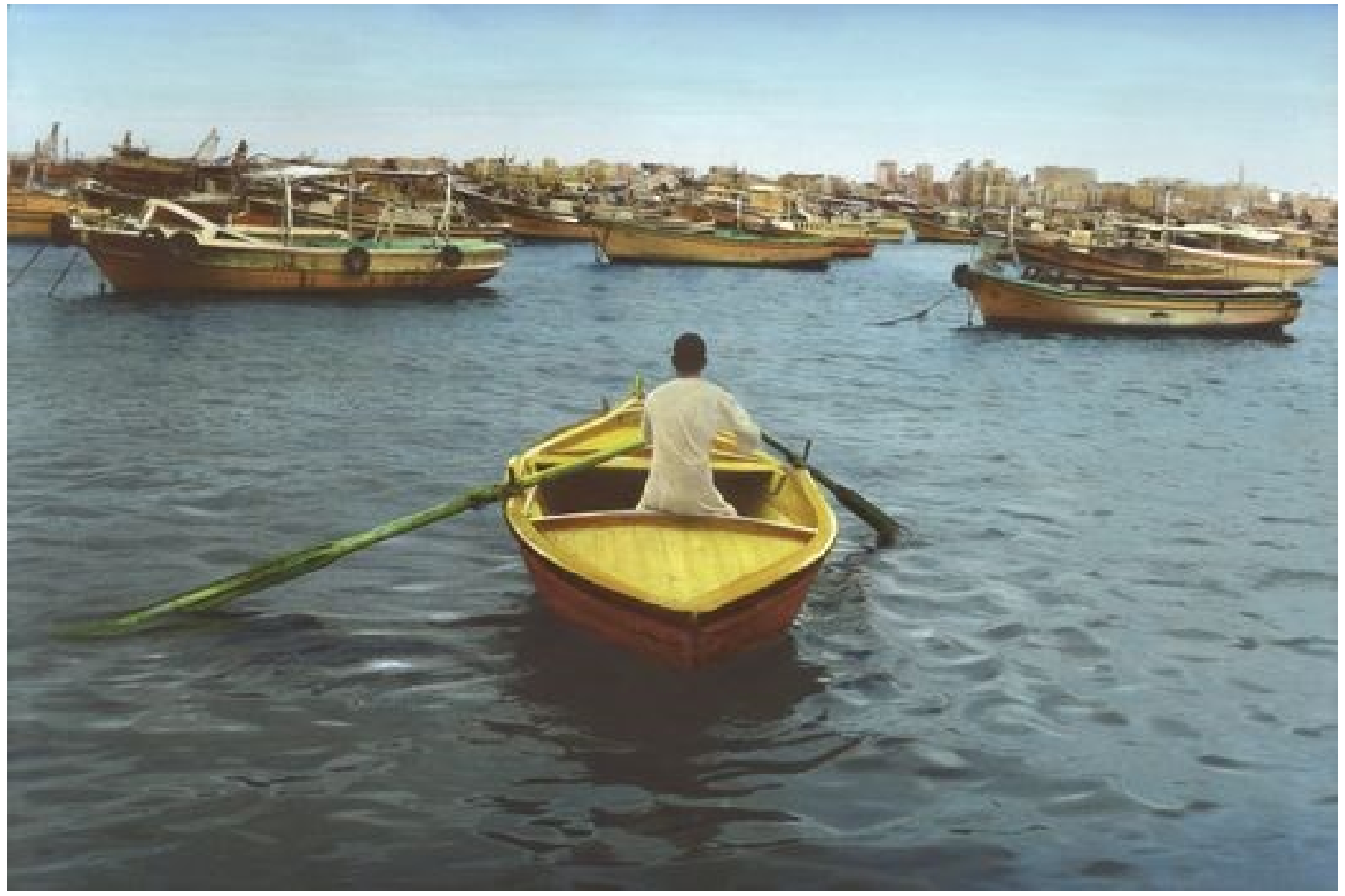

Figure K

Youssef Nabil. You Never Left \#1, 2010. Hand coloured silver gelatin print.
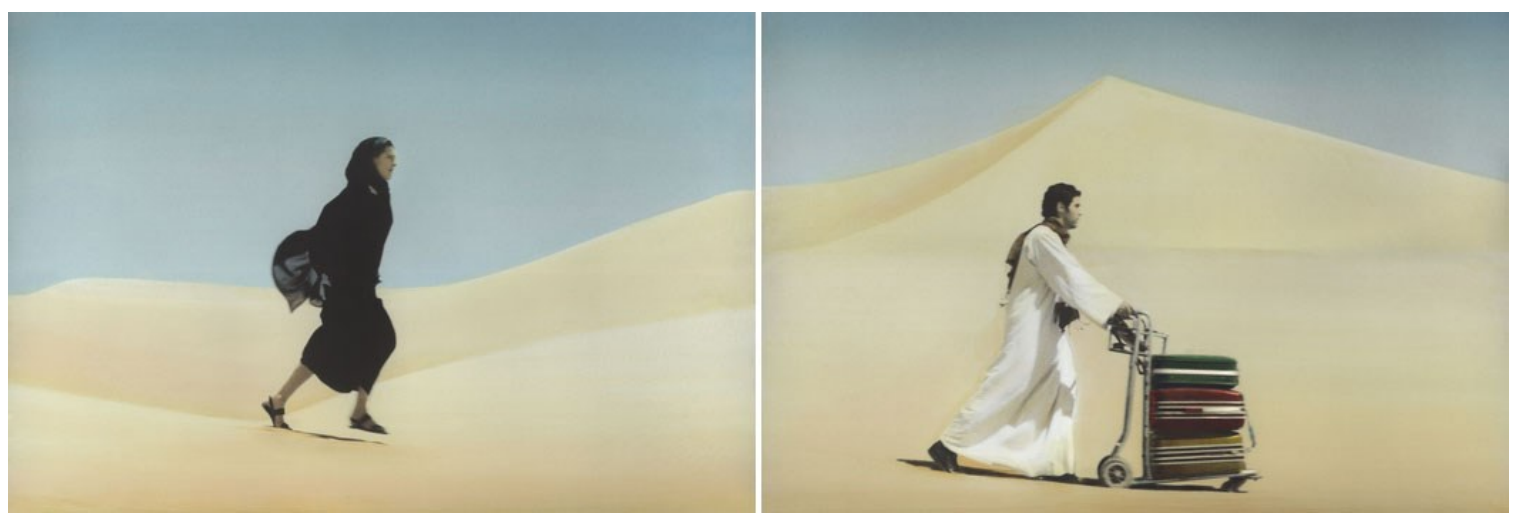
Figure L

Youssef Nabil,

Four Pyramids, Giza, 1992,

Hand coloured gelatin silver prints

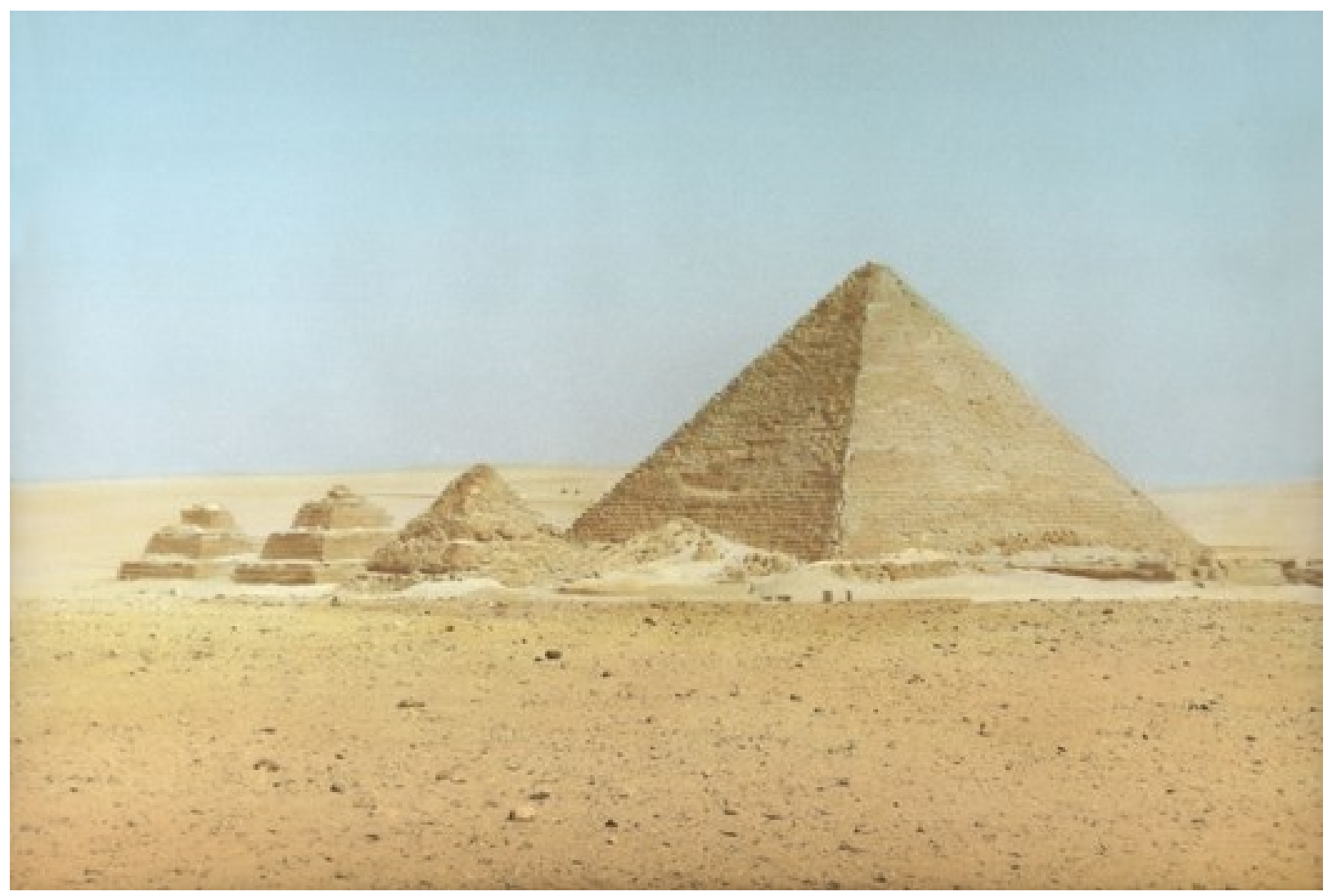


Figure M

Youssef Nabil,

Sphinx, Giza, 2008.

Hand coloured silver gelatin print.

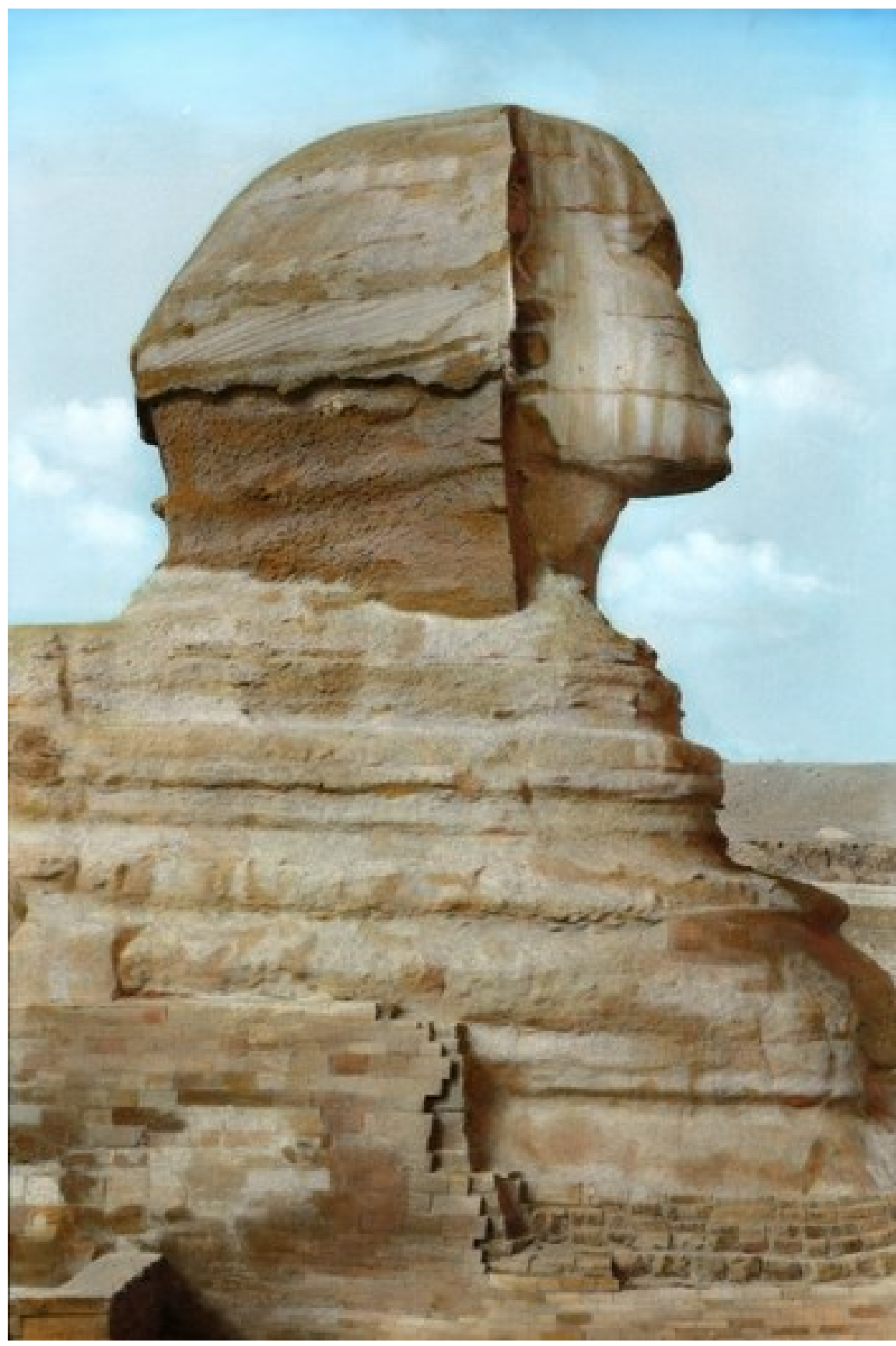


Figure N

Youssef Nabil,

Palm Trees, Cairo, 2008,

Hand coloured silver gelatin prints

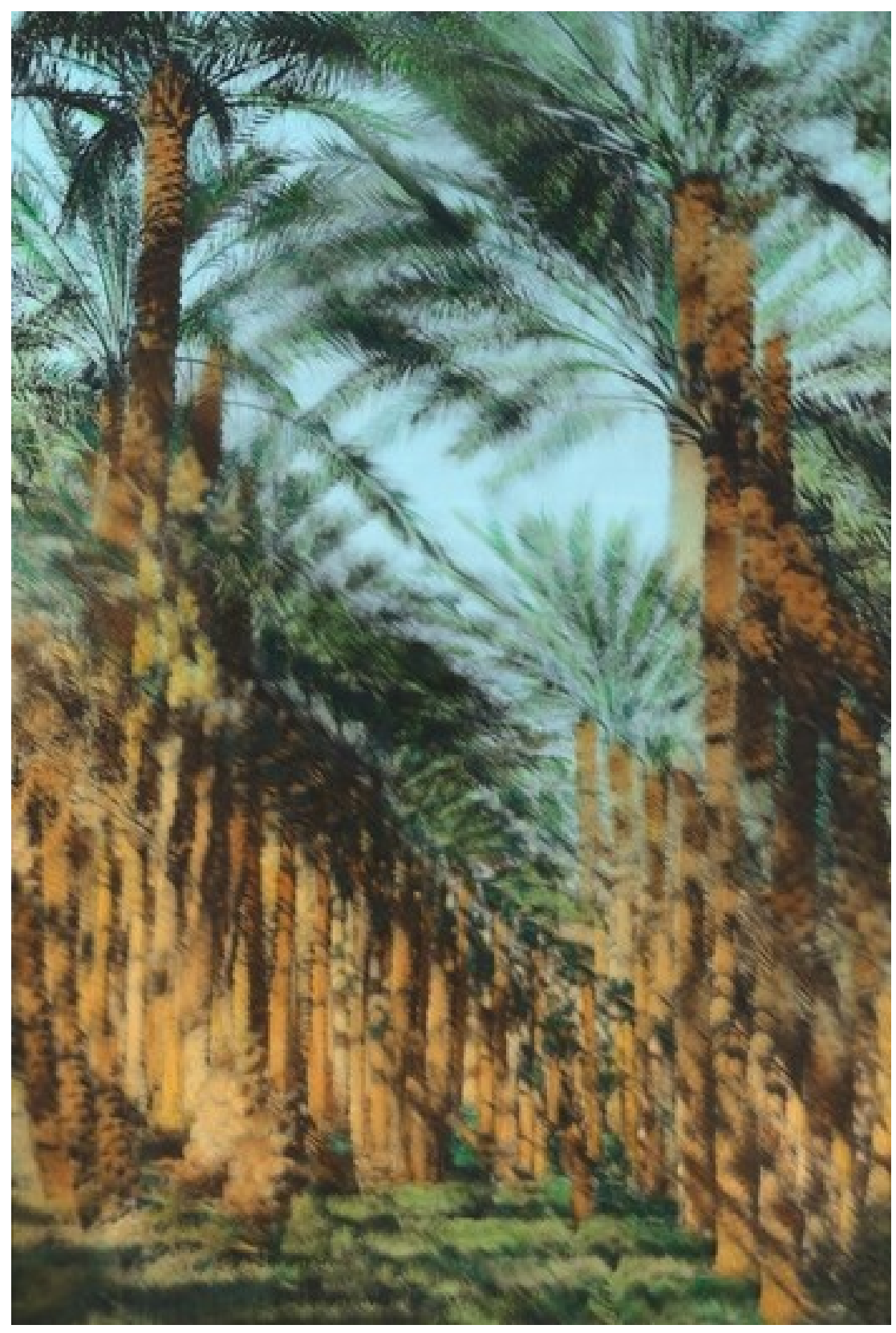


86

Figure O

Youssef Nabil,

Malik Sleeping, Paris, 2005,

Hand coloured gelatin silver print.

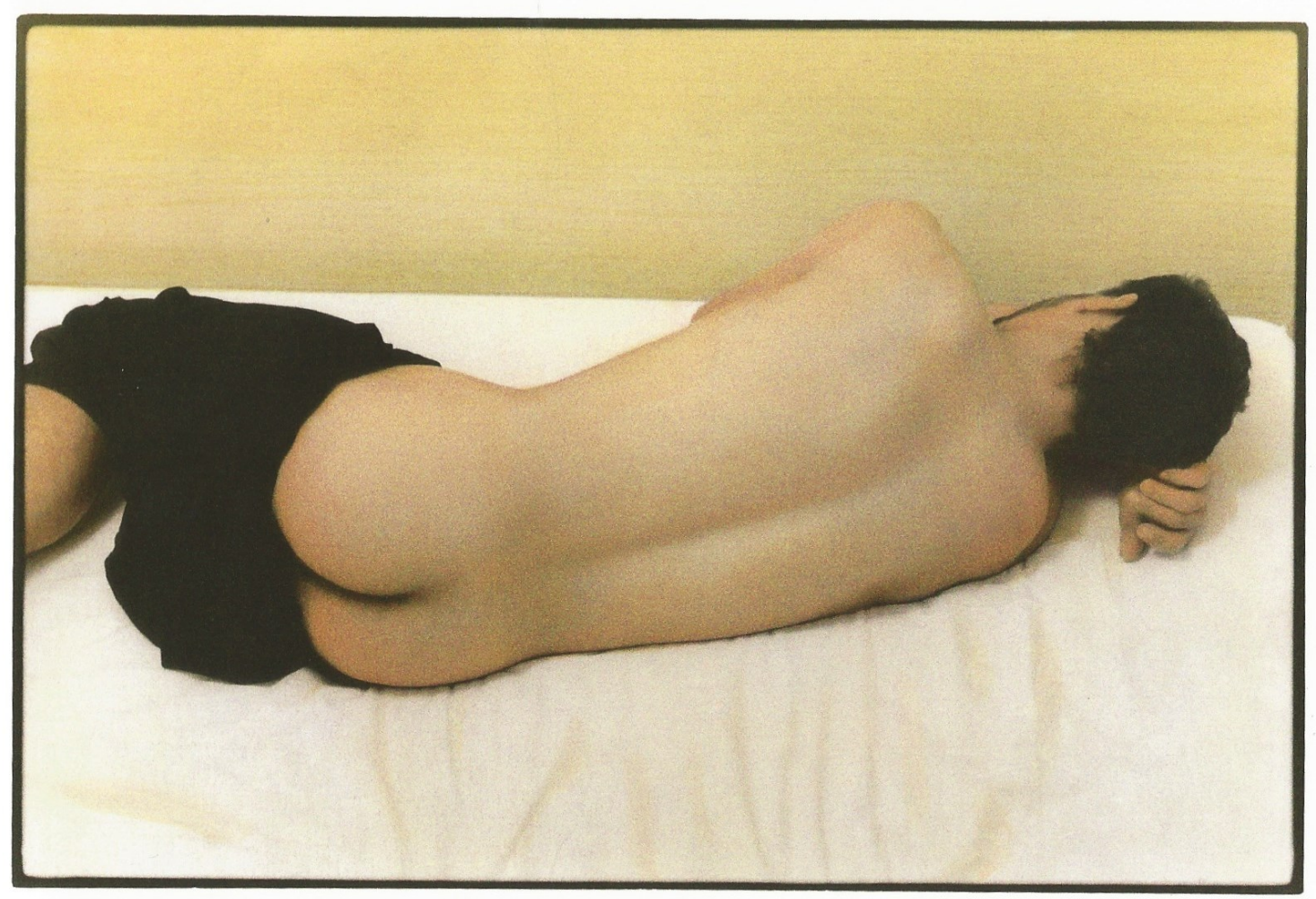


Figure $\mathrm{P}$

Youssef Nabil,

Ahmed in Djellabah, New York, 2004,

Hand coloured gelatin silver print.

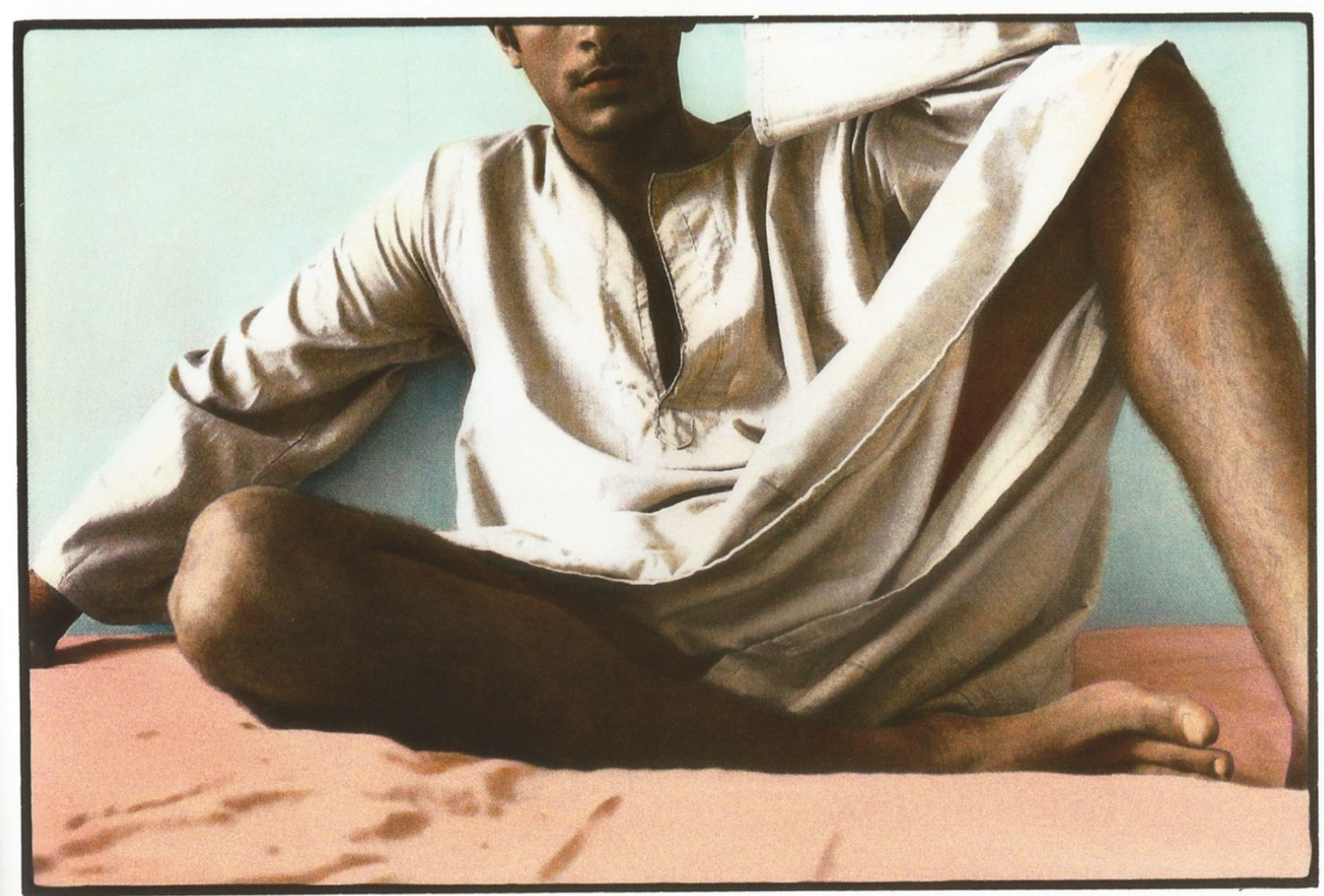


Figure Q

Youssef Nabil,

Ali in Abaya, Paris 2007,

Hand coloured gelatin silver print.

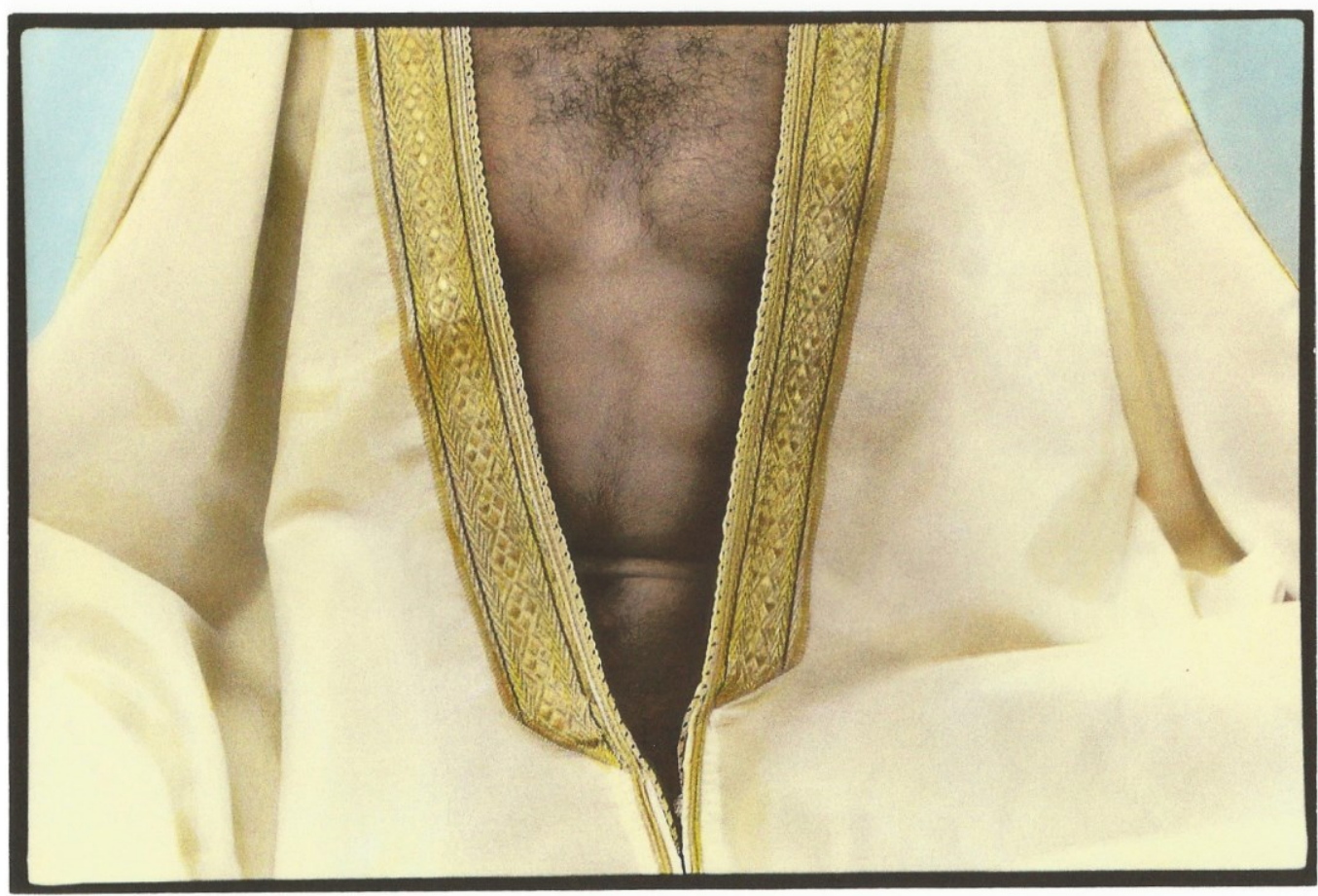


Figure R

Youssef Nabil,

What Have We Done Wrong, Cairo, 1993,

Hand coloured gelatin silver print.

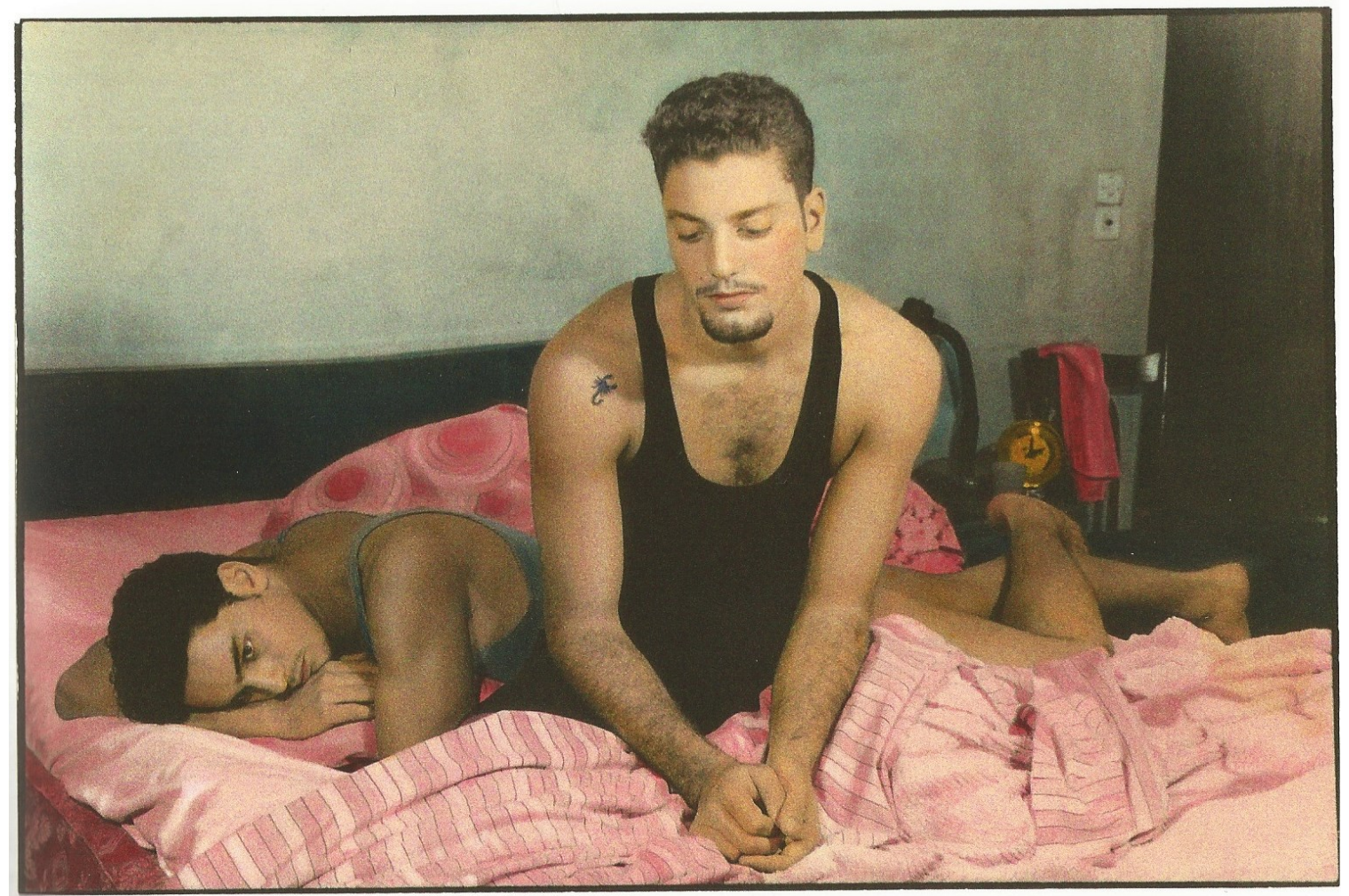


Figure S

Youssef Nabil,

Not Afraid to Love, Paris, 2005,

Hand coloured gelatin silver print.

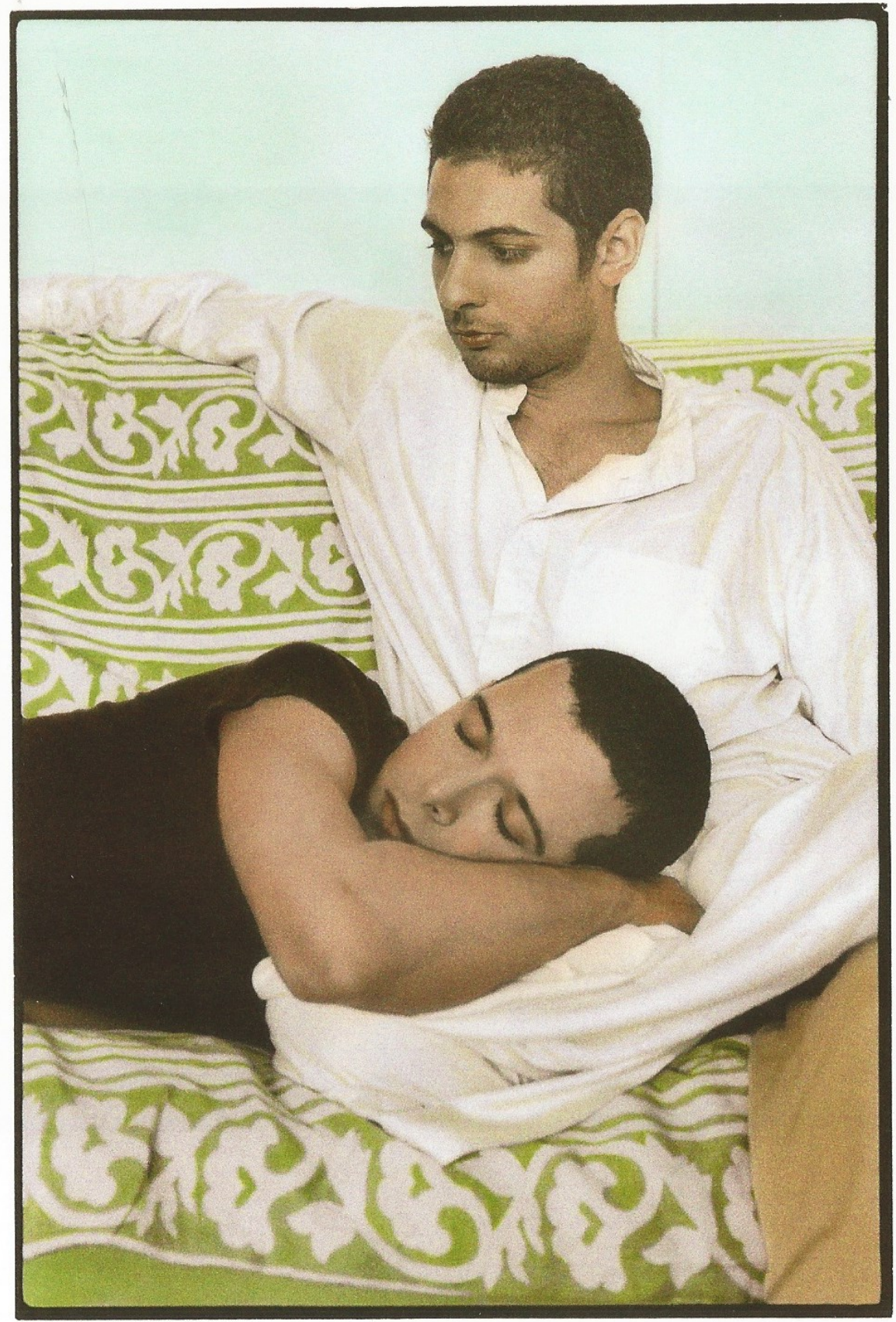


Figure T

Youssef Nabil

Rashid With a Shisha in his Mouth, Paris, 2004

Hand coloured gelatin silver print.

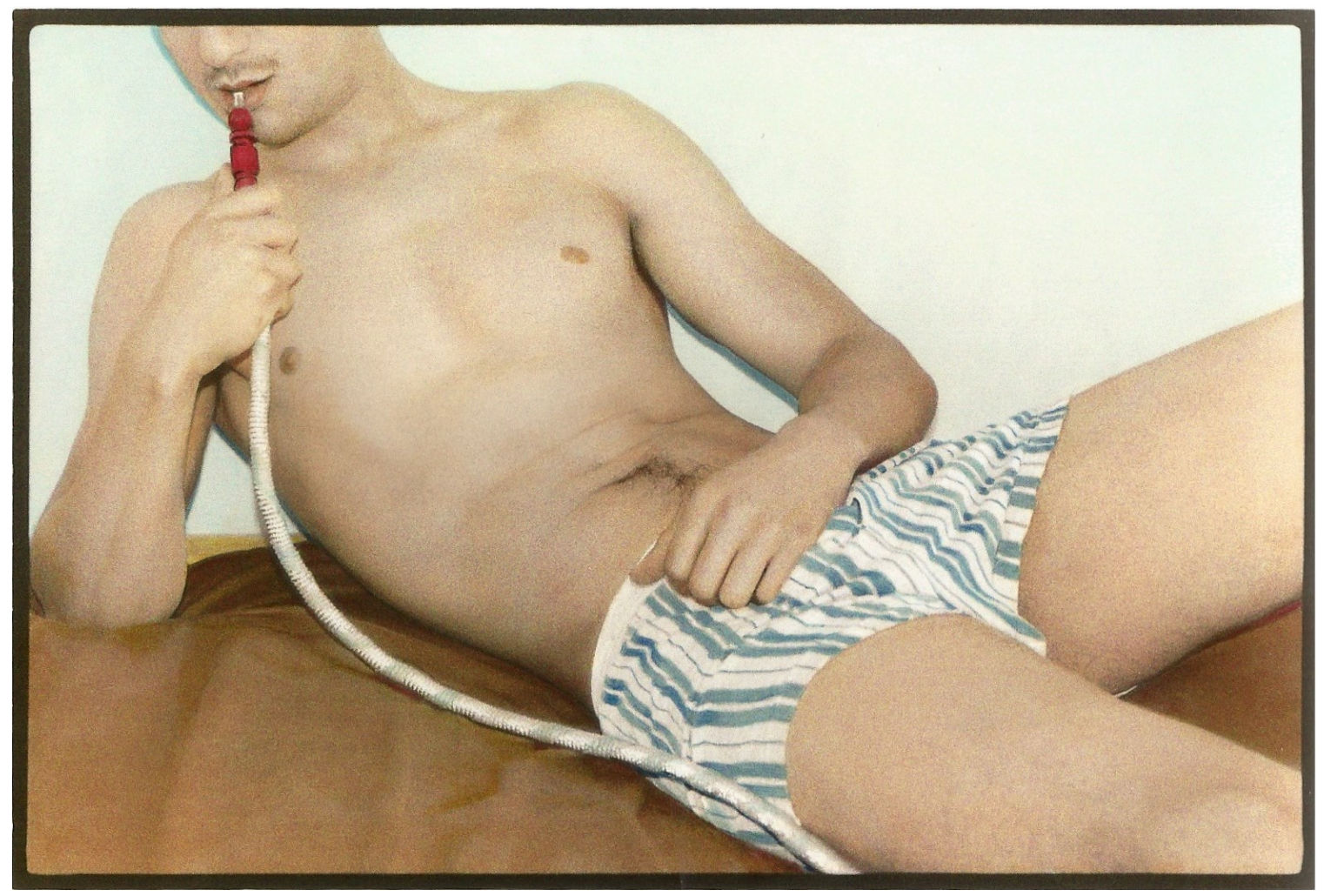


Figure U

Robert Mapplethorp.

Bryan Ridley and Lyle Heeter. 1979

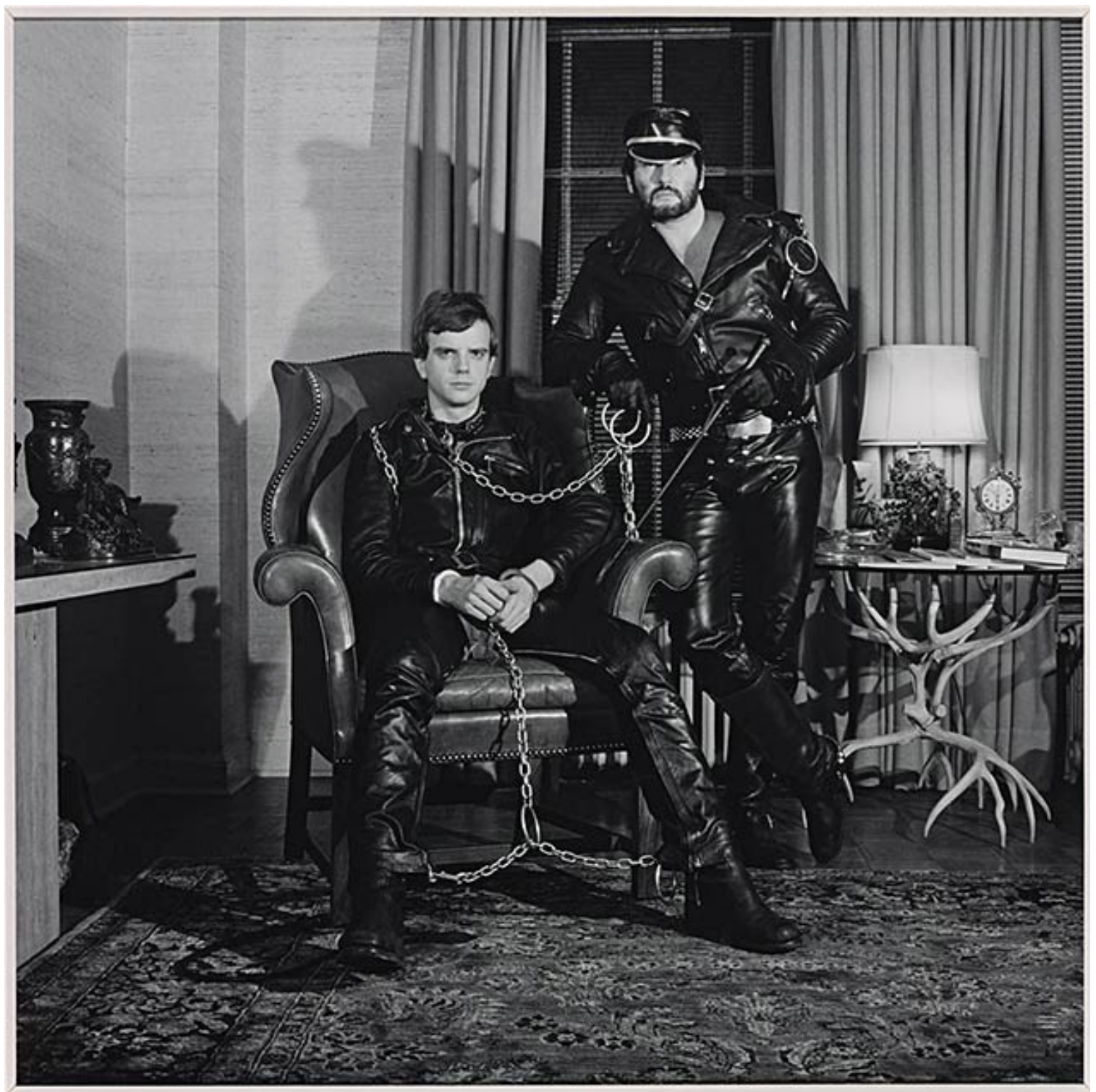


Bibliography

Abbas, M. A., Wimal Dissanayake, and John Nguyet Erni. Internationalizing Cultural Studies: An Anthology. Malden, MA: Blackwell Pub, 2005.

Abdulhadi, Rabab. "Where is Home? Fragmented Lives, Border Crossings, and the Politics of Exile." In Arab \& Arab American Feminisms Gender, Violence, \& Belonging. edited by Abdulhadi, Rabab, Evelyn Alsultany and Nadine Naber, 315. Syracuse, N.Y.: Syracuse University Press, 2011.

Abdulhadi, Rabab, Evelyn Alsultany, and Nadine Christine Naber. Arab \& Arab American Feminisms: Gender, Violence, \& Belonging. Gender, Culture \& Politics in the Middle East. 1st ed. ed. Syracuse, N.Y: Syracuse University Press, 2011.

Abramovic, Marina, Youssef Nabil, and Hans Ulrich Obrist. Youssef Nabil. Translated by Iturralde, Laetitia, edited by Rouart, Julie. Paris, France: Flammarion, 2013.

Abu-Laban, Baha. An Olive Branch on the Family Tree: The Arabs in Canada. Generations, a History of Canada's Peoples. Toronto: McClelland and Stewart, 1980.

Ade-Odutola, Kole. Diaspora and Imagined Nationality: USA-Africa Dialogue and Cyberframing Nigerian Nationhood. CAP African World Series. Durham, N.C: Carolina Academic Press, 2012.

Ahmed, Sarah. "Problematic Proximities: Or Why Critiques of Gay Imperialism Matter." Feminist Legal Studies 19, (2011): 119-132.

Ahmed, Leila,. A Border Passage: From Cairo to America-- a Woman's Journey. New York: Penguin Books, 2000.

Al-Adeeb. "Dissidents, Displacements, and Diasporas: An Interview." In Arab \& Arab American Feminisms Gender, Violence, \& Belonging. edited by Abdulhadi, Rabab, Evelyn Alsultany and Nadine Naber, 213. Syracuse, N.Y.: Syracuse University Press, 2011.

Al-Kassim, Dina. "Psychoanalysis and the Postcolonial Genealogy of Queer Theory." International Journal of Middle East Studies 45, no. 2 (2013): 343-346.

Allan, Michael. "Queer Couplings: Formations of Religion and Sexuality in 'ala' A1Aswani's 'imarat Ya'qubyan." International Journal of Middle East Studies. Volume 45, no. 2 (2013): 253-269. 
Al-Samman, Hanadi and Tarek El-Ariss. "Queer Affects: Introduction." International Journal of Middle East Studies 45, no. 2 (2013): 205-209.

Amar, Paul. The Security Archipelago: Human-security States, Sexuality Politics, and the End of Neoliberalism. Durham, N.C. ; London: Duke University Press, 2013.

Amar, Paul and Omnia El Shakry. "Introduction: Curiosities of Middle East Studies in Queer Times." International Journal of Middle East Studies 45, no. 2 (2013): 331335.

Amer, Ghada, Faten Hamama, Youssef Nabil, Shirin Neshat, and Octavio Zaya. I Won't Let You Die. Ostfildern, Germany: Hatje Cantz Verlang, 2008.

Amer, Sahar. Crossing Borders: Love between Women in Medieval French and Arabic Literatures. The Middle Ages Series. Philadelphia: University of Pennsylvania Press, 2008.

Amirsadeighi, Hossein, Salwa Mikdadi and Nada Shabout. New Vision: Arab Contemporary Art in the 21st Century. London, England, United Kingdom: Thames and Hudson in association with TransGlobe Publishing Limited, 2009.

Anderson, Benedict. Imagined Communities: Reflections on the Origin and Spread of Nationalism. Revised edited ed.ition London; New York: Verso, 2006.

Anna Brzyski. Partisan Canons. Durham:Duke University Press, 2007.

An-Na'im, Abdullahi Ahmed. Human Rights in Cross-Cultural Perspectives: A Quest for Consensus. Pennsylvania Studies in Human Rights. Philadelphia: University of Pennsylvania Press, 1992.

Appadurai, Arjun. Fear of Small Numbers: An Essay on the Geography of Anger. Durham: Duke University Press, 2006.

Appadurai, Arjun. Modernity at Large: Cultural Dimensions of Globalization. Public Worlds Series, v. 1. Minneapolis, Minn: University of Minnesota Press, 1996.

Appelbaum, Richard P. and William I. Robinson. Critical Globalization Studies. New York: Routledge, 2005.

Arat-Koc, Sedef. "Invisibilized, Individualized, and Culturalized- Paradoxical Invisibility and Hyper-Visibility of Gender in Policy Making and Policy Discourse in Neoliberal Canada." Canadian Woman Studies 29, no. 3 (Spring-Summer, 2012): 6.

Armanios, Febe and Andrew Amstutz. "Emerging Christian Media in Egypt: Clerical Authority and the Visualization of Women in Coptic Video Films." International Journal of Middle East Studies 45, no. 3 (2013): 513-533. 
Ashcroft, Bill. Edward Said. London; New York: Routledge, 2009.

Aswad, Barbara C. and Barbara Bilgâe. Family and Gender among American Muslims: Issues Facing Middle Eastern Immigrants and their Descendants. Philadelphia: Temple University Press, 1996.

Atay, Ahmet. "Touch of Pink: Diasporic Queer Experiences within Islamic Communities." In Islam and Homosexuality, edited by Samar Habib. Vol. 2, 445. Santa Barbara, Calif.: Praeger, 2010.

Awwad, Julian. "The Postcolonial Predicament of Gay Rights in the Queen Boat Affair." Communication and Critical Cultural Studies 7, no. 3 (2010): 318-336.

Axel, Brian Keith. "The Context of Diaspora." Cultural Anthropology 19, no. 1 (2004): 26-60.

Azimi, Negar, Isolde Brielmaier, Michket Krifa, and Wim Melis. Nazar: Photographs from the Arab World. Netherlands: Aperture Foundation, 2004.

Azoulay, Ariella,. The Civil Contract of Photography. New York; Cambridge, Mass.: Zone Books ; Distributed by the MIT Press, 2008.

Babayan, Kathryn and Afsaneh Najmabadi. Islamicate Sexualities: Translations Across Temporal Geographies of Desire. Harvard Middle Eastern Monographs; 39. Cambridge, Mass: Center for Middle Eastern Studies of Harvard University: Distributed by Harvard University Press, 2008.

Bahoora, Haytham. "Baudelaire in Baghdad: Modernism, the Body, and Husayn Mardan's Poetics of the Self." International Journal of Middle East Studies 45, no. 2 (2013): 313-329.

Baird, Jill, Fereshteh Daftari, Derek Gregory, Anthony Shelton, Naghmeh Sohrabi, and Jayce Salloum. Safar Voyage: Contemporary Works by Arab, Iranian, and Turkish Artists, edited by Taylor, Meg. First U.S. edition ed. Vancouver, British Columbia, Canada: Museum of Anthropology and D\&M Publishers Inc., 2013.

Bardouil, Sam, Fellrath, Till, Ellis, Andrew, Arab Museum of Modern Art (Dawhah, Qatar), Qatar Foundation.. Told Untold Retold: 23 Stories of Journeys through Time and Space. Milano, Italy; New York, NY, USA: Distributed in North America by Rizzoli International Publications, 2010.

Baron, Beth and Sara Pursley. "Editorial Foreword." International Journal of Middle East Studies 45, no. 2 (2013): 203-204.

Barone, Tom and Elliot W Eisner. Arts Based Research. Thousand Oaks: SAGE Publications, 2011. 
Barrett, Estelle, Barbara Bolt. "Practice as Research Approaches to Creative Arts Enquiry." London: I.B. Tauris, 2010.

Beaulieu, Jill and Mary Roberts. Orientalism's Interlocutors: Painting, Architecture, Photography. Objects/histories. Durham: Duke University Press, 2002.

Beckers, Tilo. Islam and the Acceptance of Homosexuality: The Shortage of Socioeconomic Well-being and Responsive Democracy, Vol. 1. Santa Barbara, Calif.: Praeger, 2010.

Bereket, Tarik and Adam Barryd. "The Emergence of Gay Identities in Contemporary Turkey." Sexualities 9, no. 2 (2006): 131-151.

Berger, John and Jean Mohr. Another Way of Telling. 1st American ed. ed. New York: Pantheon, 1982.

Berlekamp, Persis. "Visible Art, Invisible Knowledge." International Journal of Middle East Studies 45, no. 3 (2013): 563-565.

Bhabha, Homi K. The Location of Culture. Special Indian Edition. London; New York: Routledge, 2004.

Bhabha, Homi K., W. J. T. Mitchell, and Edward W. Said. Edward Said: Continuing the Conversation. Chicago: University of Chicago Press, 2005.

Bhandar, Davina. "Cultural Politics- Disciplining Citizenship." Citizenship Studies 14, no. 3 (2010): 331-343.

Booth, Marilyn. "Wayward Subjects and Negotiated Disciplines: Body Politics and the Boundaries of Egyptian Nationhood." International Journal of Middle East Studies 45, no. 2 (2013): 353-374.

Butler, Judith. Precarious Life: The Powers of Mourning and Violence. London; New York: Verso, 2004.

Butler, Judith. "Merely Cultural." Social Text no. 52/53, Queer Transexions of Race, Nation, and Gender (Autumn - Winter, 1997): 265-277.

Cable, Umayyah. "New Wave Arab American Studies- Ethnic Studies and the Critical Turn." American Quarterly 65, no. 1 (2013): 231-243.

Chase, Anthony Tirado. Human Rights, Revolution, and Reform in the Muslim World. Boulder. London: Lynne Rienner Publishers, 2012.

Chiba, Shin and Thomas J. Schoenbaum. Peace Movements and Pacifism After September 11. Cheltenham, UK; Northampton, MA: Edward Elgar, 2008. 
Chun, Jennifer Jihye, George Lipsitz, and Young Shin. "Intersectionality as a Social Movement Strategy- Asian Immigrant Women Advocates." Signs 38, no. 4 (Summer, 2013): 917.

Clifford, James. "Diasporas." CUAN Cultural Anthropology 9, no. 3 (1994): 302-338.

Cosslett, Tess, Celia Lury, and Penny Summerfield. Feminism and Autobiography: Texts, Theories, Methods. Transformations. New York: Routledge, 2000.

Darwish, Mustafa. Dream Makers on the Nile: A Portrait of Egyptian Cinema. Cairo: American University in Cairo Press, 1998.

De Sondy, Amanullah. The Crisis of Islamic Masculinities. London: Bloomsbury Academic, 2014.

Dekel, Tal. "Body, Gender and Transnationalism: Art and Cultural Criticism in a Changing Europe." Studies in Ethnicity and Nationalism 9, no. 2 (2009): 175-197.

Desai, Gaurav Gajanan and Supriya Nair. Postcolonialisms: An Anthology of Cultural Theory and Criticism. New Brunswick, N.J: Rutgers University Press, 2005.

Dobson, Kit and Aine McGlynn. Transnationalism, Activism, Art. Toronto: University of Toronto Press, 2013.

Don Kulick. "A Man in the House: The Boyfriends of Brazilian Travesti Prostitutes." Social Text no. 52/53, Queer Transexions of Race, Nation, and Gender (Autumn Winter, 1997): 133-160.

Donaldson, Mike. Migrant Men: Critical Studies of Masculinities and the Migration Experience. Routledge Research in Gender and Society ; 20. New York: Routledge, 2009.

Eigner, Saeb and Zaha Hadid. Art of the Middle East: Modern and Contemporary Art of the Arab World and Iran. London, England: Merrell Publishers Limited, 2010.

El-Alam, Johnny. Representing National Traumas: Alternative Histories, Experimental Art Practices and Narratives by Transnational Artists from the Lebanese War Generation (2010). Carleton University, M.A dissertation.

El-Ariss, Tarek. "Majnun Strikes Back: Crossings of Madness and Homosexuality in Contemporary Arabic Literature." International Journal of Middle East Studies 45, no. 2 (2013): 293-312.

El-Aswad, El-Sayed. "Geographies of Muslim Identities: Diaspora, Gender and Belonging." Digest of Middle East Studies 17, no. 1 (2008): 163. 
El-Aswad, El-Sayed,. "Narrating the Self among Arab Americans: A Bridging Discourse between Arab Tradition and American Culture." Digest of Middle East Studies 19, no. 2 (2010): 234-248.

Elkins, James. Is Art History Global? Art Seminar; v. 3. New York; London: Routledge, 2007.

Elliott, Emory, Jasmine Payne, and Patricia Ploesch. Global Migration, Social Change, and Cultural Transformation. 1st ed. ed. New York: Palgrave Macmillan, 2007.

El-Rouayheb, Khaled. Before Homosexuality in the Arab-Islamic World, 1500-1800. Chicago: University of Chicago Press, 2005.

El-tayeb, Fatima. "Gays Who Cannot Properly be Gay- Queer Muslims in the Neoliberal European City." European Journal of Women's Studies 19, no. 1 (2012): 79-95.

Emin, Tracy, Youssef Nabil, Simon Njami, Mark Sealy, and Michael Stevenson. Sleep in My Arms. South Africa: Cape Town, 2007.

Endsjø, D. ø. "The Queer Periphery: Sexual Deviancy and the Cultural Understanding of Space." Journal of Homosexuality 54, no. 1 (2008): 9-20.

Eng, David L. "Out here and Over there: Queerness and Diaspora in Asian American Studies." Social Text no. 52/53, Queer Transexions of Race, Nation, and Gender (Autumn - Winter, 1997): 31-52.

Engin F. Isin. "Citizenship After Orientalism, an Unfinished Project." Citizenship Studies. Volume 16, no. 5-6 (2012).

Eriksen, Thomas Hylland. Ethnicity and Nationalism: Anthropological Perspectives. 3rd ed. ed. London; New York : New York: Pluto Press ; Distributed in the United States of America exclusively by Palgrave Macmillan, 2010.

Evans, Tony and Alison J. Ayers. "In the Service of Power- the Global Political Economy of Citizenship and Human Rights." Citizenship Studies 10, no. 3 (2006): 289-308.

Everett, Anna. Digital Diaspora: A Race for Cyberspace. Suny Series, Cultural Studies in cinema/video. Albany: State University of New York Press, 2009.

Falola, Toyin, Niyi Afolabi, and Aderonke Adesola Adesanya. Migrations and Creative Expressions in Africa and the African Diaspora. Durham, N.C: Carolina Academic Press, 2008.

Ferber, Abby L., Kimberly Holcomb, and Tre Wentling. Sex, Gender, and Sexuality: The New Basics, An Anthology. New York: Oxford University Press, 2009. 
Flood, Finbarr Barry. "Lost Histories of a Licit Figural Art." International Journal of Middle East Studies 45, no. 3 (2013): 566-569.

Fraser, Nancy. "Heterosexism, Misrecognition, and Capitalism: A Response to Judith Butler." Social Text no. 52/53, Queer Transexions of Race, Nation, and Gender (Autumn - Winter, 1997): 279-289.

Gelfer, Joseph. Masculinities in a Global Era. International and Cultural Psychology, 4. New York, NY: Springer, 2014.

Gelfer, Joseph. Masculinities in a Global Era, edited by Joseph Gelfer, editor New York, NY: Springer, c2014, 2014.

Georgis, Dina. "Thinking Past Pride: Queer Arab Shame in Bareed mista3jil." International Journal of Middle East Studies 45, no. 2 (2013): 233-251.

Georgis, Dina. The Better Story: Queer Affects from the Middle East. Albany: SUNY Press, 2013.

Ghosh, Ranjan, Edward Said. Edward Said and the Literary, Social, and Political World. New York, U.S.A: Routledge, 2009.

Ghoussoub, Mai and Emma Sinclair-Webb. Imagined Masculinities: Male Identity and Culture in the Modern Middle East. London: Saqi, 2000.

Gioni, Massimiliano, Gary Carrion-Murayari, Natalie Bell, Negar Azimi, Kaelen WilsonGoldie, Media Farzin, and Yasmine El Rashidi. Here and Elsewhere. New York, NY.: New Museum, 2014.

Goltz, Dustin Bradley. Queer Temporalities in Gay Male Representation: Tragedy, Normativity, and Futurity. Routledge Studies in Rhetoric and Communication; v. 2. New York: Routledge, 2010.

Gopinath, Gayatri. Impossible Desires: Queer Diasporas and South Asian Public Cultures. Durham, N.C: Duke University Press, 2005.

Habib, Samar. "Introduction: Islam and Homosexuality." In Islam and Homosexuality. Vol. 1. Santa Barbara, Calif.: Praeger, 2010.

Habib, Samar. "Introduction: Islam and Homosexuality." In Islam and Homosexuality. Vol. 2. Santa Barbara, Calif:: Praeger, 2010.

Hadeed, Khalid. "Homosexuality and Epistemic Closure in Modern Arabic Literature." International Journal of Middle East Studies 45, no. 2 (2013): 271-291. 
Halberstam, Judith. "Mackdaddy, Superfly, Rapper: Gender, Race, and Masculinity in the Drag King Scene." Social Text no. 52/53, Queer Transexions of Race, Nation, and Gender (Autumn - Winter, 1997): 104-131.

Hale, C. Jacob. "Leatherdyke Boys and their Daddies: How to have Sex without Women Or Men." Social Text no. 52/53, Queer Transexions of Race, Nation, and Gender (Autumn - Winter, 1997): 223-236.

Hall, Stuart. "Cultural Identity and Diaspora." In Identity: Community, Culture, Difference. London, UK.: Lawrence \& Wishart, 1998. 222.

Hall, Stuart and Brian Meeks. Culture, Politics, Race and Diaspora : The Thought of Stuart Hall. Caribbean Reasonings. Kingston ; Miami : London: Ian Randle Publishers ; Lawrence \& Wishart, 2007.

Hammond, Andrew,.. Popular Culture in the Arab World: Arts, Politics, and the Media. Cairo, Egypt; New York: American University in Cairo Press ; 2007.

Hammound-Beckett, Sekneh. "Azima Ila Hayati- an Invitation in to My Life: Narrative Conversations about Sexual Identity." International Journal of Narrative Therapy and Community Work 2007, no. 1 (2007): 29-39.

Hamzić, Vanj. "The Case of 'Queer Muslims'- Sexual Orientation and Gender Identity in International Human Rights Law and Muslim Legal and Social Ethos." Human Rights Law Review 11, no. 2 (2011): 237-274.

Harper, Phillip Brian. "Gay Male Identities, Personal Privacy, and Relations of Public Exchange: Notes on Directions for Queer Critique." Social Text no. 52/53, Queer Transexions of Race, Nation, and Gender (Autumn - Winter, 1997): 5-29.

Harper, Phillip Brian, Anne McClintock, José Esteban Muñoz, and Trish Rosen. "Queer Transexions of Race, Nation, and Gender: An Introduction." Social Text no. 52/53, Queer Transexions of Race, Nation, and Gender (Autumn - Winter, 1997): 1-4.

Hart, William D. Edward Said and the Religious Effects of Culture. Cambridge Studies in Religion and Critical Thought. Cambridge, U.K. ; New York: Cambridge University Press, 2000.

Haseman, Brad. "A Manifesto for Performative Research." Media International Australia, Incorporating Culture \& Policy no. 118 (2006): 98-106.

Hatem, Mervat. "The Political and Cultural Representations of Arabs, Arab Americans, and Arab American Feminisms After September 11, 2001." In Arab and Arab American Feminisms: Gender, Violence and Beloning. edited by Abdulhadi, Rabab, Evelyn Alsultany and Nadine Naber. Syracuse, N.Y: Syracuse University Press, 2011. 
Hegde, Radha Sarma. Circuits of Visibility: Gender and Transnational Media Cultures. Critical Cultural Communication. New York: New York University Press, 2011.

Hennebry, Jenna, Bessma Momani. Targeted Transnationals: The State, the Media, and Arab Canadians. Vancouver: UBC Press, 2013.

Hesse-Biber, Sharlene Nagy. Feminist Research Practice: A Primer. 2nd Ed.

Hesse-Biber, Sharlene Nagy and Patricia Leavy. Feminist Research Practice a Primer. Thousand Oaks: SAGE Publications, 2007.

Hodgson, Marshall G. S. The Venture of Islam: Conscience and History in a World Civilization. Chicago: University of Chicago Press, 1974.

Hodgson, Marshall G. S. and Edmund Burke. Rethinking World History: Essays on Europe, Islam, and World History. Studies in Comparative World History. Cambridge [England]; New York, NY, USA: Cambridge University Press, 1993.

Holmes, Rachel. "Queer Comrades: Winnie Mandela and the Moffies." Social Text no. 52/53, Queer Transexions of Race, Nation, and Gender (Autumn - Winter, 1997): 161-180.

Hourani, Albert. A History of the Arab Peoples. [New edition] ed. London: Faber, 2002.

Hughes, Craig, Stevie Peace, and Kevin Van Meter. Uses of a Whirlwind: Movement, Movements, and Contemporary Radical Currents in the United States. Edinburgh; Oakland: AK, 2010.

Human Rights Watch (Organization). In a Time of Torture: The Assault on Justice in Egypt's Crackdown on Homosexual Conduct. New York: Human Rights Watch, 2004.

Inhorn, Marcia Claire. The New Arab Man: Emergent Masculinities, Technologies, and Islam in the Middle East. Princeton, NJ: Princeton University Press, 2012.

Isin, Engin F. "Citizenship After Orientalism, an Unfinished Project." Citizenship Studies 16, no. 5-6 (August, 2012).

Iversen, Margaret, Francis Barker, and Peter Hulme. Colonial Discourse, Postcolonial Theory. Essex Symposia, Literature, Politics, Theory. Manchester [England]; New York: New York: Manchester University Press ; Distributed exclusively in the USA and Canada by St. Martin's Press, 1994.

Iyall Smith, Keri E. and Patricia Leavy. Hybrid Identities: Theoretical and Empirical Examinations. Studies in Critical Social Sciences, v. 12. Leiden; Boston: Brill, 2008. 
Jackson, Ronald L. and Murali Balaji. Global Masculinities and Manhood. Urbana: University of Illinois Press, 2011.

Jackson, Ronald L. and Jamie E. Moshin. Communicating Marginalized Masculinities: Identity Politics in TV, Film, and New Media. Routledge Studies in Rhetoric and Communication; 11. New York: Routledge, 2013.

Jacob, Wilson Chacko. "The Middle East: Global, Postcolonial, Regional, and Queer." International Journal of Middle East Studies 45, no. 2 (2013): 347-349.

Jamshīdī, Maryam. The Future of the Arab Spring: Civic Entrepreneurship in Politics, Art, and Technology Startups. Oxford: Butterworth-Heinemann: Elsevier, 2013.

Jones, Amelia. Seeing Differently: A History and Theory Identification and the Visual Arts. [1st ed.] Abingdon, Oxon [England] ; New York, NY: Routledge, 2012.

Kabesh, Amal Treacher. Postcolonial Masculinities: Emotions, Histories and Ethics. The Feminist Imagination: Europe and Beyond.

Kalra, Virinder S., John Hutnyk, and Raminder Kaur. Diaspora \& Hybridity. Theory, Culture \& Society (Unnumbered). London ; Thousand Oaks, CA: SAGE Publications, 2005.

Kamalipour, Yahya R. Media, Power, and Politics in the Digital Age: The 2009 Presidential Election Uprising in Iran. Lanham: Rowman \& Littlefield Publishers, 2010.

Karnouk, Liliane. Modern Egyptian Art: 1910-2003. New Revised Edition ed. Cairo, Egypt: The American University in Cairo Press, 2005.

Kelly, Christopher Grant. "Is there a "Gay-Friedly" Islam? Synthesizing Tradition and Modernity in the Question of Homosexuality in Islam." In Islam and Homosexuality. edited by Habib, Samar. Vol. 2, 247. Santa Barbara, Calif.: Praeger., 2010.

Kelly, Christopher Grant. "The Social Construction of Religious Realities by Queer Muslims." In Islam and Homosexuality, edited by Habib, Samar. Vol. 2, 223. Santa Barbara, Calif.: Praeger., 2010.

Khair, Tabish. "Can the Subaltern Shout (and Smash?)." World Literature Written in English 38, no. 2 (2000): 7-16.

Khalaf, Samir and John H. Gagnon. Sexuality in the Arab World. London; San Francisco: Saqi, 2006. 
Khan, Badruddin. "Longing, Not Belonging, and Living in Fear." In Islam and Homosexuality. edited by Habib, Samar. Vol. 1, 23. Santa Barbara, Calif.: Praeger., 2010.

Khan, Fatima Mahruq. "Queer, American, and Muslim: Cultivating Identities and Communities of Affirmation." In Islam and Homosexuality. edited by Habib, Samar. Vol. 2, 347. Santa Barbara, Calif.: Praeger., 2010.

Khan, Mohamed. An Introduction to the Egyptian Cinema. London: Informatics, 1969.

King, Anthony D. Culture, Globalization and the World-System: Contemporary Conditions for the Representation of Identity. Current Debates in Art History; 3. Binghamton, N.Y: State University of New York at Binghamton, Dept. of Art and Art History, 1991.

Kokot, Waltraud, Khachig Tèolèolyan, and Carolin Alfonso. Diaspora, Identity, and Religion New Directions in Theory and Research. London: Routledge, 2004.

Kugle, Scott. Homosexuality in Islam: Critical Reflection on Gay, Lesbian, and Transgender Muslims. Oxford: Oneworld, 2010.

Kugle, Scott and Stephen Hunt. "Masculinity, Homosexuality and The Defense of Islam: A Case of Yusuf Al-Qaradawi's Media Fatwa." Religion and Gender 2, no. 2 (2012): 254.

Kugle, Scott. Living Out Islam: Voices of Gay, Lesbian, and Transgender Muslims. New York: New York University Press, 2014.

Landreau, John C. and Nelson M. Rodriguez. Queer Masculinities a Critical Reader in Education. Explorations of Educational Purpose; v. 21. Dordrecht; New York: Springer Science+Business Media B.V, 2012.

Lavie, Smadar and Ted Swedenburg. Displacement, Diaspora, and Geographies of Identity. Durham: Duke University Press, 1996.

Lawrence, Tim. "AIDS, the Problem of Representation, and Plurality in Derek Jarman's Blue." Social Text no. 52/53, Queer Transexions of Race, Nation, and Gender (Autumn - Winter, 1997): 241-264.

Lewis, Reina and Sara Mills. Feminist Postcolonial Theory: A Reader. Edinburgh: Edinburgh University Press, 2003.

Lindström, Christina, Elie Wardini, Fataneh Farahani, and Elie Wardini. "Narratives of Lesbian Existence in Egypt: Coming to Terms with Identities." Stockholms Universitet, Humanistiska Fakulteten, Institutionen För Orientaliska Språk, Avdelningen För Mellanösternstudier (2009). 
Lockman, Zachary. Contending Visions of the Middle East the History and Politics of Orientalism. Contemporary Middle East ; 3. Cambridge ; New York: Cambridge University Press, 2004.

MacCloud, Aminah B. Transnational Muslims in American Society. Gainesville, U.S.A: University Press of Florida, 2006.

Mahon, Alyce. Eroticism \& Art. Oxford History of Art. Oxford; New York: Oxford University Press, 2007.

Manalansan, Martin F. Global Divas: Filipino Gay Men in the Diaspora. Perverse Modernities. Durham: Duke University Press, 2003.

Marien, Mary Warner. 100 Ideas that Changed Photography. edited by Wise, Sophie. London, England: Laurence King Publishing, 2012.

Martin, Florence. Screens and Veils: Maghrebi Women's Cinema. New Directions in National Cinemas. Bloomington: Indiana University Press, 2011.

Mascia-Lees, Frances E. Gender \& Difference in a Globalizing World: Twenty-First Century Anthropology. Long Grove, Ill: Waveland Press, 2010.

Masquelier, Adeline Marie. Dirt, Undress, and Difference: Critical Perspectives on the Body's Surface. Bloomington: Indiana University Press, 2005.

Massad, Joseph Andoni. "Re-Orienting Desire: The Gay International and the Arab World." Public Culture 14, no. 2 (2002): 361-385.

Massad, Joseph Andoni. Desiring Arabs. Chicago: University of Chicago Press, 2007.

Mau, Steffen. Social Transnationalism: Lifeworlds Beyond the Nation State. International Library of Sociology. Abingdon, Oxon; New York, NY: Routledge, 2010.

Mayer, Ann Elizabeth. International Journal of Middle East Studies 45, no. 2 (2013): 389-391.

Mejcher-Atassi, Sonja. "Art and Political Dissent in Postwar Lebanon: Walid Sadek's Fi Annani Akbar Min Bikasu [Bigger than Picasso]." International Journal of Middle East Studies 45, no. 3 (2013): 535-560.

Mesch, Claudia. Art and Politics: A Small History of Art for Social Change since 1945. London: New York: I.B. Tauris \& Co, 2013.

Meskimmon, Marsha and Dorothy Rowe. Women, the Arts and Globalization: Eccentric Experience. Rethinking Art's Histories. Manchester. England: Manchester University Press, 2013. 
Metta, Marilyn, "Writing Against, Alongside and Beyond Memory : Lifewriting as Reflexive Poststructuralist Feminist Research Practice." Curtin University of Technology, School of Occupational Therapy and Social Work. 2009.

Mignolo, Walter. The Darker Side of Western Modernity: Global Futures, Decolonial Options. Durham: Duke University Press, 2011.

Mikdashi, Maya. "Queering Citizenship, Queering Middle East Studies." International Journal of Middle East Studies 45, no. 2 (2013): 350-352.

Milton-Edwards, Beverley. Contemporary Politics in the Middle East. Cambridge, UK; Malden, MA: Polity Press ; Blackwell Publishers, 2000.

Mirzoeff, Nicholas. The Visual Culture Reader. 2nd ed. ed. London: Routledge, 2002.

Mitter, Partha. "Interventions - Decentering Modernism: Art History and Avant-Garde Art from the Periphery." The Art Bulletin 90, no. 4 (2008): 531.

Moffatt, Kenneth James. Troubled Masculinities Reimagining Urban Men. Toronto [Ont.]: University of Toronto Press, 2012.

Moghadam,Valentine M. Globalizing Women: Transnational Feminist Networks. Baltimore: Johns Hopkins University Press, 2005.

Momin, Rahman. "Queer as Intersectionality: Theorizing Gay Muslim Identities." Sociology 44, no. 5 (2010): 944-961.

Momin, Rahman. Homosexualities, Muslim Cultures and Modernity. Basingstoke: Palgrave Macmillan, 2014.

Morris, Rosalind C. "Educating Desire: Thailand, Transnationalism, and Transgression." Social Text no. 52/53, Queer Transexions of Race, Nation, and Gender (Autumn Winter, 1997): 53-79.

Muñoz, José Esteban. "Disidentifications Queers of Color and the Performance of Politics." Cultural Studies of the Americas 2, (1999).

Muñoz, José Esteban. Cruising Utopia: The then and there of Queer Futurity. Sexual Cultures. New York: New York University Press, 2009.

Muñoz, José Esteban. "The White to be Angry": Vaginal Davis's Terrorist Drag." Social Text no. 52/53, Queer Transexions of Race, Nation, and Gender (Autumn - Winter, 1997): 80-103.

Mufti, Aamir R. "Global Comparativism." Critical Inquiry 31, no. 2 (2005): 472-489. 
Murray, Stephen O. and Will Roscoe. Islamic Homosexualities: Culture, History, and Literature. New York: New York University Press, 1997.

Naber, Nadine. "Decolonizing Culture: Beyond Orientalist and Anti-Orientalist Femanisms." In Arab and Arab American Feminisms: Gender, Violence and Beloning. edited by Abdulhadi, Rabab, Evelyn Alsultany and Nadine Naber, 78. Syracuse, N.Y.: Syracuse University Press, 2011.

Naber, Nadine Christine. Arab America: Gender, Cultural Politics, and Activism. Nation of Newcomers: Immigrant History as American History. New York: New York University Press, 2012.

Najmabadi, Afsaneh. "Mapping Transformations of Sex, Gender, and Sexuality in Modern Iran." Social Analysis 49, no. 2 (Summer, 2005): 52-76.

Najmabadi, Afsaneh. "Types, Acts, Or what? Regulations of Sexuality in NineteenthCentury Iran." In Islamicate Sexualities: Translations Across Temporal Geographies of Desire., edited by Babayan, Kathryn and Afsaneh Najmabadi, 275-296.

Cambridge, Mass: Center for Middle Eastern Studies of Harvard University., 2008.

Najmabadi, Afsaneh. "Genus of Sex Or the Sexing of Jins." International Journal of Middle East Studies 45, no. 2 (2013): 211-231.

Najmabadi, Afsaneh. Women with Mustaches and Men without Beards: Gender and Sexual Anxieties of Iranian Modernity. Berkeley: University of California Press, 2005.

Najmabadi, Afsaneh. "SPECIAL SECTION - Reorienting Sexuality: Reflections on the Study of Sexuality in the Middle East and North Africa - Mapping Transformations of Sex, Gender, and Sexuality in Modern Iran." Social Analysis. 49, no. 2 (2005): 54.

Naples, Nancy A. Feminism and Method: Ethnography, Discourse Analysis, and Activist Research. New York: Routledge, 2003.

Nayak, Anoop and Mary Jane Kehily. Gender, Youth, and Culture: Young Masculinities and Femininities. Second edition. Basingstoke [England]: Palgrave Macmillan, 2008.

Nelson, Robin. Practice as Research in the Arts: Principles, Protocols, Pedagogies, Resistances. Basingstoke: Palgrave Macmillan, 2013.

O'Brien, Elaine. Modern Art in Africa, Asia, and Latin America: An Introduction to Global Modernisms. Chichester, West Sussex; Malden, MA: Wiley-Blackwell, 2013. 
Okome, Mojubaolu Olufunke and Olufemi Vaughan. Transnational Africa and Globalization. New York, N.Y: Palgrave Macmillan, 2011.

Olick, Jeffrey K., Vered Vinitzky-Seroussi, and Daniel Levy. The Collective Memory Reader. New York: Oxford University Press, 2011.

Ore, Tracy E. The Social Construction of Difference and Inequality: Race, Class, Gender, and Sexuality. 5th ed. ed. Dubuque: McGraw-Hill, 2011.

Ouzgane, Lahoucine. Islamic Masculinities. Global Masculinities. London; New York : New York: Zed Books ; Distributed in the USA by Palgrave Macmillan, 2006.

Owen, Roger. State, Power and Politics in the Making of the Modern Middle East. 3rd ed. ed. London; New York: Routledge, 2004.

Pearlstone, Zena, Allan J. Ryan, and Joanna Woods-Marsden. About Face: Self-Portraits by Native American, First Nations, and Inuit Artists. Santa Fe, NM: Wheelwright Museum of the American Indian, 2006.

Porter, Venetia, Issabelle Caussé, and Saeb Eigner. Word into Art: Artists of the Modern Middle East. London, England: The British Museum Press, 2006.

Puar, Jasbir K. "Queer Times, Queer Assemblages." Social Text 84, no. 85 (2005): 121 139.

Puar, Jasbir K. "Rethinking Homonationalism." International Journal of Middle East Studies 45, no. 2 (2013): 336-339.

Puar, Jasbir K. Terrorist Assemblages: Homonationalism in Queer Times. Next Wave. Durham: Duke University Press, 2007.

Rayside, David M. and Clyde Wilcox. Faith, Politics, and Sexual Diversity in Canada and the United States. Vancouver: UBC Press, 2011.

Ritchie, Jason. "How do You Say "Come Out of the Closet" in Arabic? Queer Activism and the Politics of Visibility in Israel-Palestine." Glq 16, no. 4 (2010): 557-575.

Roberta, Julian. "Hmong Transnational Identity: The Gendering of Contested Discourses." Hmong Studies Journal 5, no. 1 (2005): 1.

Robinson, Tracy L. The Convergence of Race, Ethnicity, and Gender: Multiple Identities in Counseling. 2nd ed. ed. Upper Saddle River, N.J: Pearson/Merrill Prentice Hall, 2005.

Rogoff, Irit. Terra Infirma: Geography's Visual Culture. London ; New York: Routledge, 2000. 
Rolling,James Haywood, Jr. "A Paradigm Analysis of Arts-Based Research and Implications for Education." Studies in Art Education: A Journal of Issues and Research in Art Education 51, no. 2 (2010): 102-114.

Rouhi, Leyla. "A Handsome Boy among those Barbarous Turks: Cervante's Muslims and the Art and Science of Desire." In Islamicate Sexualities: Translations Across Temporal Geographies of Desire. , edited by Babayan, Kathryn and Afsaneh Najmabadi, 41-71. Cambridge, Mass: Center for Middle Eastern Studies of Harvard University, 2008.

Rowson, Everett. "Homoerotic Lisaisons among the Mamluk Elite in Late Medieval Egypt and Syria." In Islamicate Sexualities: Translations Across Temporal Geographies of Desire., edited by Babayan, Kathryn and Afsaneh Najmabadi, 204238. Cambridge, Mass: Center for Middle Eastern Studies of Harvard University, 2008 .

Rydzik, Agnieszka, Annette Pritchard, Nigel Morgan, and Diane Sedgley. "The Potential of Arts-Based Transformative Research." Annals of Tourism Research 40, (2013): 283-305.

Saatchi Gallery. Unveiled: New Art from the Middle East. London, UK.: Booth-Clibborn Editions, 2009.

Safran, William. "Diasporas in Modern Societies: Myths of Homeland and Return." Diaspora: A Journal of Transnational Studies. 1, no. 1 (1991): 83-99.

Said, Edward W. Reflections on Exile and Other Essays. Convergences. Cambridge, Mass: Harvard University Press, 2000.

Said, Edward W. Culture and Imperialism. 1st ed. ed. New York: Knopf : Distributed by Random House, 1993.

Said, Edward W. Reflections on Exile and Other Essays. Convergences. Cambridge, Mass: Harvard University Press, 2000.

Sajed, Alina. Postcolonial Encounters in International Relations : The Politics of Transgression in the Maghreb. Interventions.

Savage, Michael, Brian Longhurst, and Gaynor Bagnall. Globalization and Belonging. Theory, Culture \& Society (Unnumbered). London; Thousand Oaks, Calif: SAGE, 2005 .

Schulman, Sarah. Israel/Palestine and the Queer International. Durham [N.C.]: Duke University Press, 2012. 
Sedgwick, Eve Kosofsky. "A Response to C. Jacob Hale." Social Text no. 52/53, Queer Transexions of Race, Nation, and Gender (Autumn - Winter, 1997): 237-239.

Shakhsari, Sima. "Transnational Governmentality and the Politics of Life and Death." International Journal of Middle East Studies 45, no. 2 (2013): 340-342.

Sharlet, Jocelyn. "Public Displays of Affection: Male Homoerotic Desire and Sociability in Medieval Arabic Liturature." In Islam and Homosexuality. edited by Habib, Samar. Vol. 1, 37. Santa Barbara, Calif.: Praeger., 2010.

Shryock, Andrew. Off Stage / on Display: Intimacy and Ethnography in the Age of Public Culture. Stanford, Calif: Stanford University Press, 2004.

Sloman, Paul. Contemporary Art in the Middle East. London: Black Dog, 2009.

Smalls, James. Homosexuality in Art. Temporis Collection. New York, USA: Parkstone, 2003.

Smith, Terry. Contemporary Art: World Currents, edited by Antoniou, Zoe. London, England: Laurence King Publishing, 2011.

Smith, Linda Tuhiwai. Decolonizing Methodologies: Research and Indigenous Peoples. 2nd ed. ed. London; New York: Zed Books : Distributed in the USA exclusively by Palgrave Macmillan, 2012.

Smith, Terry. Contemporary Art: World Currents. Upper Saddle River [N.J.]: Prentice Hall, 2011.

Spivak, Gayatri Chakravorty. A Critique of Postcolonial Reason: Toward a History of the Vanishing Present. Cambridge, Mass: Harvard University Press, 1999.

Stam, Robert and Ella Shohat. Race in Translation : Culture Wars Around the Postcolonial Atlantic. New York: New York University Press, 2012.

Stein, Marc. Encyclopedia of Lesbian, Gay, Bisexual, and Transgender History in America. New York: Thomson Learning, 2004.

Sullivan, Graeme. Art Practice as Research: Inquiry in the Visual Arts. Thousand Oaks, Calif.: Sage Publications, 2005.

Teverson, Andrew and Sara Upstone. Postcolonial Spaces: The Politics of Place in Contemporary Culture. Basingstoke, Hampshire; New York: Palgrave Macmillan, 2011.

Tiampo, Ming. "Decentering Paris," in Okqui Postwar-Art Between the Pacific and the Atlantic, 1945-1965, Enwezor, Ulrich Wilmes, Atreyee Gupta eds. Forthcoming. 
Traub, Valerie. "The Past is a Foreign Country? The Times and Spaces of Islamicate Sexuality Studies." In Islamicate Sexualities: Translations Across Temporal Geographies of Desire. , edited by Babayan, Kathryn and Afsaneh Najmabadi, 1-40. Cambridge, Mass.: Center for Middle Eastern Studies of Harvard University, 2008.

Trevelyan, C., Crath, R.,Chambon, A.,. "Promoting Critical Reflexivity through ArtsBased Media: A Case Study." British Journal of Social Work British Journal of Social Work 44, no. 1 (2014): 7-26.

Valentine, David and Riki Anne Wilchins. "One Percent on the Burn Chart: Gender, Genitals, and Hermaphrodites with Attitude." Social Text no. 52/53, Queer

Transexions of Race, Nation, and Gender (Autumn - Winter, 1997): 215-222.

Waisanen, Don. "Bordering Populism in Immigration Activism-Outlaw-Civic Discourse in a (Counter)Public." Communication Monographs 79, no. 2 (2012): 232-255.

Wald, Kenneth D. "Homeland Interests, Hostland Politics: Politicized Ethnic Identity among Middle Eastern Heritage Groups in the United States." The International Migration Review 42, (2008): 273-301.

Wald, Priscilla. "Cultures and Carriers: "Typhoid Mary" and the Science of Social Control." Social Text no. 52/53, Queer Transexions of Race, Nation, and Gender (Autumn - Winter, 1997): 181-214.

Watriss, Wendy, Karin Adrian von Roques, Samer Mohdad, Claude W. Sui, and Mona Khazindar. View from Inside: Contemporary Arab Photography, Video and Mixed Media Art. Houston, Texas, USA: FotoFest ; Amsterdam, NL.: Schilt Publishing, 2014.

Whitaker, Brian. Unspeakable Love: Gay and Lesbian Life in the Middle East. Los Angeles, CA: University of California Pr./ Saqi Books, 2006.

Wolff, Kurt H. The Sociology of George Simmel. London: Free Press of Glencoe, 1950.

Wood, Paul. Western Art and the Wider World. Chichester: Wiley Blackwell, 2014.

Zabaleta, Marta Raquel. "Exile." Feminist Review Spring, no. 73 (2003): 19-38. 